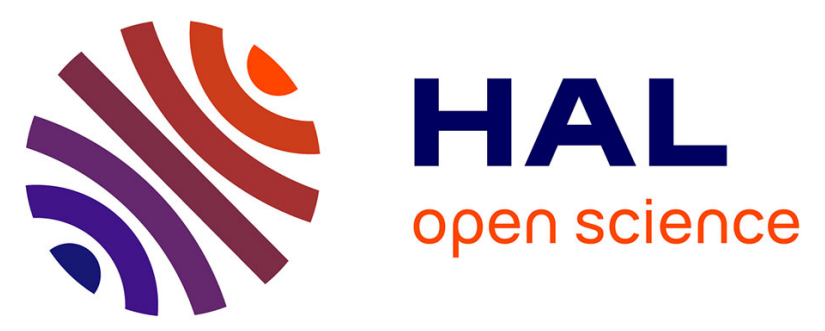

\title{
Shortening of the European Dauphinois margin (Oisans Massif, Western Alps): New insights from RSCM maximum temperature estimates and 40Ar/39Ar in situ dating
}

\author{
Mathieu Bellanger, Romain Augier, Nicolas Bellahsen, Laurent Jolivet, \\ Patrick Monié, Thierry Baudin, Olivier Beyssac
}

\section{To cite this version:}

Mathieu Bellanger, Romain Augier, Nicolas Bellahsen, Laurent Jolivet, Patrick Monié, et al.. Shortening of the European Dauphinois margin (Oisans Massif, Western Alps): New insights from RSCM maximum temperature estimates and $40 \mathrm{Ar} / 39 \mathrm{Ar}$ in situ dating. Journal of Geodynamics, 2015, 83, pp.37-64. 10.1016/j.jog.2014.09.004 . insu-01093878

\section{HAL Id: insu-01093878 \\ https://hal-insu.archives-ouvertes.fr/insu-01093878}

Submitted on 9 Jan 2015

HAL is a multi-disciplinary open access archive for the deposit and dissemination of scientific research documents, whether they are published or not. The documents may come from teaching and research institutions in France or abroad, or from public or private research centers.
L'archive ouverte pluridisciplinaire HAL, est destinée au dépôt et à la diffusion de documents scientifiques de niveau recherche, publiés ou non, émanant des établissements d'enseignement et de recherche français ou étrangers, des laboratoires publics ou privés. 
11 Shortening of the European Dauphinois margin (Oisans Massif, Western Alps): new insights from RSCM maximum temperature estimates and ${ }^{40} \mathrm{Ar} /{ }^{39} \mathrm{Ar}$ in situ dating.

13

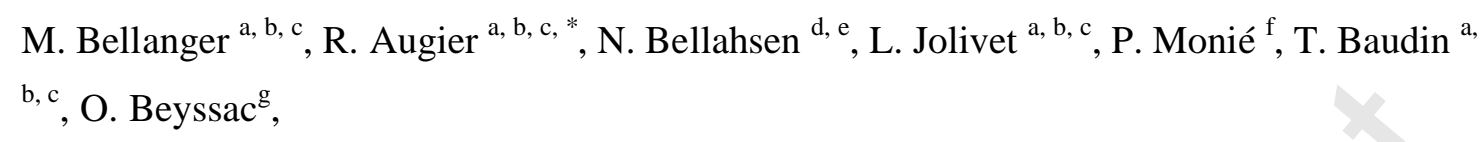

\section{Abstract}

The Oisans Massif, located in the external zones of the western Alps, experienced significant shortening during the Alpine collision. While a series of major top-to-the west shear zones was recently described, the general low grade of the metamorphism has not attracted much petrological and geochronological studies. This paper provides combined temperature and age constraints on the evolution of the Oisans Massif. Temperature was estimated with the Raman Spectrometry of Carbonaceous Material (RSCM) method and chlorite geothermometry. Maximum temperature reached by the Mesozoic cover (Tmax) from Grenoble to the Galibier pass (E-W) and from Saint Jean de Maurienne to Embrun (NS) yielded almost constant ca. $330^{\circ} \mathrm{C}$ temperatures all through the Massif. Temperatures however strongly decrease either westward toward the top of the Vercors sedimentary sequence or eastward toward the Penninic Frontal Thrust. Age constraints were retrieved using ${ }^{40} \mathrm{Ar} /{ }^{39} \mathrm{Ar}$ in situ analyses performed on variously strained samples from Alpine shear zones. Over strain gradients, incipient Alpine recrystallizations progressively develop at the expense of former Variscan parageneses. A combined textural and EPMA approach permitted to identify newly formed chlorite and phengite that unequivocally grew in response to deformation or to low grade metamorphism. Chlorites recorded temperatures from ca. 350 to $150^{\circ} \mathrm{C}$ during the activity of shear zones. In parallel, ${ }^{40} \mathrm{Ar} /{ }^{39} \mathrm{Ar}$ in situ 
experiments enabled dating deformation using both synkinematic phengites crystallized below the closure temperature of white-micas and former Variscan muscovite whose isotopic system have been, at least partially re-opened. Activity of top-to-the-west shear zones responsible for the shortening and thickening of the Oisans massif thus occurred between 34-33 and 25 Ma. Integrating these new age-constraints, Tmax estimates, and published geological data on the Oisans Massif and neighbouring areas allow proposing a new shortening scenario for the external zones. From ca. 34-33 Ma, the Oisans Massif was buried as a rigid block below more internal units and reached temperature of ca. $330^{\circ} \mathrm{C}$. Shearing progressively localized along a series of top-to-the-W shear zones in the basement until 25 Ma. Deformation then localised along a major thrust at the base of the ECM massif and propagated along the basement-cover interface below the Vercors massif after 16Ma.

\section{Introduction}

The involvement of basement units in the external zones of collisional orogens is still poorly understood because the associated deformation is not intense and metamorphic conditions not severe enough to erase the effects of earlier deformation episodes, rendering the syn-collision deformation difficult to recognize. The deformation and kinematic history of these continental units thus often remains partly enigmatic and the rheology of the crust in the early stages of collision poorly known.

The Oisans Massif, which belongs to the External Crystalline Massifs (ECM) of the Western Alps is a key-place to understand the first stages of continental collision. Major basement brittle/ductile shear zones reworking the earlier Variscan fabric have been recognized which have accommodated most of the collisional shortening (Wibberley, 1999, 2005; Bellahsen et al., 2012, 2014; Bellanger et al., 2014; Boutoux et al., 2014a), but precise P, T, time data are still lacking to better constrain the sequence of shortening and thickening.

The Oisans Massif also comprises a Mesozoic sedimentary cover, mainly deposited during the Early Jurassic rifting episode, which has not seen the Variscan metamorphic conditions and can thus be used to assess the Alpine history. Bellahsen et al. (2012) and Bellanger et al. (2014) have shown that localised west-verging Alpine shear zones developed in the basement during collision while the cover was strongly folded above without a major décollement in between. The geometry and kinematics of these shear zones is thus now established and it remains to estimate the P-T conditions of their development and to date them. 
In this contribution, we first provide a map of the maximum temperature (Tmax) reached by the cover between Grenoble and the Galibier pass (E-W) and between Saint Jean de Maurienne and Embrun (N-S) (Fig. 1) using the RSCM method (Beyssac et al., 2002). It constrains the thermal history as well as the burial dynamics around the Oisans Massif. Then, we compare these Tmax with temperatures obtained in both basement and cover, using two chlorite geothermometers (Cathelineau and Nieva, 1985; Cathelineau, 1988; Vidal et al., 2001, 2005, 2006). In a second step, we provide EPMA analyses of white micas coupled to detailed microstructural and textural analysis of samples collected from various shear zones, in order to document the nature of these white micas, i.e. inherited vs. synkinematic. Finally, in a third step we performed in situ dating of white micas using the ${ }^{40} \mathrm{Ar} /{ }^{39} \mathrm{Ar}$ method. These results constrain the scenario of collisional shortening in the external zones of the Western Alps.

\section{Geological setting}

\subsection{The Oisans Massif within the Western Alps}

The Belledonne, Grandes Rousses, and Oisans massifs belong to the external zones and more particularly to the Dauphinois zone of the Western Alps (Fig. 1). External zones, which mainly recorded the Liassic rifting stage and the Oligo-Miocene collision event, were affected by a low-grade metamorphism after the end of Eocene. These massifs are parts of the External Crystalline Massifs (noted ECM, thereafter) that correspond to uplifted Variscan basement covered by Mesozoic to Cenozoic sedimentary series. The ECM were underthrusted below an orogenic prism made of stacked continental (Briançonnais zone) and oceanic (Piemontais zone) nappes transported along the Penninic Frontal Thrust (PFT). The PFT, also called the Crustal Pennine Thrust or the Embrunais Basal Thrust in Dumont et al. (2011, 2012) was active with top-to-the-(north-)west motion during the Early Oligocene (Ceriani et al., 2001; Tricart et al., 2001, 2006). The internal zones, east of the PFT (Fig. 1), corresponds to the subducted continental margin of Europe and the Ligurian Ocean. They are pervasively affected by high-pressure low-temperature (HP/LT) metamorphism, which occurred between 70 and $35 \mathrm{Ma}$ (Rosenbaum and Lister, 2005; Berger and Bousquet, 2008). During the Palaeozoic, the Oisans Massif experienced a complex tectonometamorphic history (Debon and Lemmet, 1999; Guillot and Menot, 1999; Von Raumer et al., 1999; Guillot et al., 2009). High-grade Carboniferous metamorphism has strongly overprinted previous tectonometamorphic records. The Oisans Massif mainly consists of late Variscan 
113 granites and earlier Devono-Dinantian plutonic and younger volcano-sedimentary

114 sequences, including Visean conglomerates, volcano-sedimentary and coal intercalations

115 (Barféty and Pêcher, 1984). The Belledonne and Rochail massifs were then structured by 116 nappe stacking during the Visean and later affected by late Carboniferous to early Permian 117 late-orogenic gravitational collapse (Guillot and Menot, 1999), contemporaneous with 118 partial-melting and plutons emplacement between 330-290 Ma and the formation of 119 extensional Stephano-Westphalian continental basins (i.e. in Grandes Rousses, Belledonne 120 and La Mure massifs) (Barféty and Pêcher, 1984; Barféty et al., 1984, 1988; Guillot et al., 121 2009). This zone was ultimately eroded during Permian to Triassic times as evidenced by 122 the continental Permo-Triassic deposits (sandstones and conglomerates together with coal 123 intercalations) and middle to late Triassic shallow marine sediments (dolomitic limestone 124 with evaporitic layers). These formations remained attached to the basement during Alpine 125 deformation, and the contact can thus be used as a reference surface to quantify both the 126 extensional strain during the rifting episode and the later compressional deformation during 127 collision (Dumont et al., 2008, 2011; Bellahsen et al., 2012, 2014; Bellanger et al., 2014; 128 Boutoux et al., 2014a).

129 During early Liassic times, the post-Variscan basement was stretched during the rifting 130 episode (Dumont, 1988; Dumont et al., 1998), as evidenced by basaltic flows ("spilites") 131 (Laurent, 1992) and a series of large-scale fault-bounded tilted blocks, limited by major 132 normal faults that still shape the present-day geometry of the external zones (Barféty and 133 Gidon, 1983; Lemoine et al., 1986; Lemoine and De Graciansky, 1988). During the early 134 Liassic, the Meije block (Fig. 3) was a horst, as evidenced by a condensed sedimentary 135 cover and shallow paleobathymetric conditions (Roux et al., 1988; Bouillin et al., 1997; 136 Corna et al., 1997).

137 After the rifting stage, the Liguro-Piemontais oceanic domain formed between the European 138 and Apulian continental domains from the Bajocian onward, as evidenced by the age of the 139 first sediments deposited above the ocean floor (De Wever and Caby, 1981; De Wever et al., 140 1987). Subduction of the Ligurian domain, which started during late Cretaceous times was 141 followed by subduction of the leading edge of the European continental margin under the 142 Apulian microplate as evidenced by the HP to UHP metamorphism in the internal zones 143 (e.g., Chopin, 1984; Agard et al., 2001). The more proximal margin was subducted to 144 shallow depths and shortened and the deformation propagated outward.

145 The "Pyreneo-Provençal phase", Late Cretaceous to Early Eocene in age, responsible for E$146 \mathrm{~W}$ folds and thrusts especially in the southern part of the external zone, is the first post- 
147 Variscan shortening event (Lemoine, 1972; Caby, 1973). Ante-Senonian E-W fold axes

148 described in the Dévoluy massif, were recently interpreted as due to submarine sliding

149 (Michard et al., 2010). The Nummulitic series are deposited within the foreland flexural 150 basin from Lutetian/Bartonian to Priabonian/Rupelian (Sinclair, 1997; Du Fornel et al., 2004

151 Mulder et al., 2010). They uncomformably overly reverse faults associated to N-S 152 shortening, south of the Oisans Massif (Ford, 1996). The timing and the kinematics of other 153 thrusts north of the Oisans Massif, such as the Meije or Combeynot thrusts, are debated, 154 whether they are pre- (Barbier, 1963; Bravard and Gidon, 1979; Ford, 1996), or syn- to post155 Nummulitic (Beach, 1981b; Dumont et al., 2011; Bellanger et al., 2014). The only evidence 156 of N-S to NW-SE Oligocene shortening within the basement is restricted to a narrow area 157 around the PFT (Bellanger et al., 2014).

158 The main Alpine collisional tectonometamorphic event in the external zones was thus due to 159 its burial under the internal units immediately after the deposition of a Rupelian olistostrome 160 topping the Nummulitic series, the so-called "schistes à blocs" (Kerckhove, 1969; Gidon and 161 Pairis, 1980; Sinclair, 1997; Mulder et al., 2010). In the Oisans Massif, E-W shortening was

162 responsible for folding in the cover with axial plane cleavage development in the west 163 (Gratier and Vialon, 1980; Bellahsen et al., 2012; Bellanger et al., 2014). The metamorphic 164 peak reached 300 to $350^{\circ} \mathrm{C}$ for 1-5 kbar (Waibel, 1990; Jullien and Goffé, 1993; Crouzet et 165 al., 1999, 2001; Ceriani et al., 2003), which implies a tectonic overburden of around 10km 166 when considering a normal geothermal gradient. The temperature in the Bourg d'Oisans area 167 (Crouzet et al., 1999, 2001) reached $330^{\circ} \mathrm{C}$ after the end of deformation. The metamorphic 168 peak was dated with large uncertainties around 26-24 Ma by K-Ar method in fine clay fraction from the cover (Nziengui, 1993), zircon fission-tracks ages ranging between $27 \mathrm{Ma}$

170 (alt. 3065m) and $13 \mathrm{Ma}$ (alt. 1310m) (van der Beek et al., 2010). A deformation stage was 171 dated between 34 and $27 \mathrm{Ma}$ by ${ }^{40} \mathrm{Ar} /{ }^{39} \mathrm{Ar}$ phengite ages from strike-slip shear zones related 172 to E-W shortening in the eastern part of the Oisans Massif (Simon-Labric et al., 2009). 173 Bellahsen et al. (2012) and Bellanger et al. (2014) have further proposed that the E-W 174 shortening in the Oisans Massif was mainly accommodated by kilometer-scale top-to-the175 west reverse shear zones, which are summarized in the next section.

176

\subsection{Inherited or newly formed: the Oisans shear zones revisited}

178 Contrary to the internal zones where deformation is too intense to preserve former 179 structures, the amount of shortening of the Oisans Massif was less than ca. 30-40\% during 180 the Alpine collision (Dumont et al., 2008; Bellahsen et al., 2012, 2014; Bellanger et al., 
2014). As a consequence, inherited structures are still preserved, which allows studying relationships between inherited and Alpine newly formed structures. The detailed structural evolution of the Oisans Massif, which is beyond the scope of the present paper, was recently investigated by Bellahsen et al. (2012) and Bellanger et al. (2014) in order to describe the distribution of the deformation in the basement.

The Oisans Massif presents unambiguous evidence of intense shortening either at small (outcrop) scale or at large (kilometric) scale. Maps of shortening axes of small-scale structures together with transport directions over the whole Oisans Massif reveal only one major E-W shortening stage (Fig. 2). Strain localization in the basement leads to the formation of a set of newly-formed, top-to-the-west, reverse shear zones that fold the basement-cover interface to the west and form large basement thrusts near the Penninic

192 Frontal Thrust (Bellanger et al., 2014). Alpine shear zones can be separated from the

193 Variscan deformation by the lower-temperature, more localised character of the deformation that cross-cuts a former high-temperature, pervasive Variscan fabrics. Moreover, an Alpine age is ensured by the deformation with consistent top-to-the-west kinematics within the Triassic-Liassic tegument (Bartoli et al., 1974; Barféty and Pêcher, 1984; Bellahsen et al., 2012; Bellanger et al., 2014).

While similar Alpine shear zones of Argentera or Mont Blanc massifs were recently dated from the Oligo-Miocene (Rolland et al., 2008; Sanchez et al., 2011a; Cenki-Tok et al., 2013), the only recent constraints on the timing of the Alpine deformation were performed on strike-slip shear zones of the eastern Oisans Massif (Simon-Labric et al., 2009). The most prominent structures accommodating most of the shortening, W-directed reverse shear zones remain therefore undated.

\section{Aims and methods}

To put age-constraints on reverse shear zones developed during collision in the Oisans Massif, deformed rocks of four main shear zones were sampled across the W- E

210 Combeynot shear zones (Fig. 2), all sharing a common and consistent E-W to SE-NW

211 stretching lineation and an overall top-to-the-west sense of shear. In situ ${ }^{40} \mathrm{Ar} /{ }^{39} \mathrm{Ar}$ laser 212 ablation method (Maluski and Monié, 1988) was chosen as it allows linking 213 radiochronology to petrology and particularly to textures/structures (Agard et al., 2002; 214 Müller, 2003; Augier et al., 2005; Gerber, 2008). This link is particularly important as 
215 different parameters such as temperature, deformation or fluid circulations may drastically

216 impact the behaviour of the K/Ar system. It is therefore crucial is to decipher the respective

217 contribution of these parameters to isolate the signal related to deformation.

218 To ensure a reliable $\mathrm{T}$ record, temperatures were constrained at the scale of the Oisans

219 Massif and the neighbouring areas using the Raman Spectrometry of Carbonaceous Material

220 method (RSCM; Beyssac et al., 2002; Lahfid et al., 2010). These data were supplemented by

221 local temperature estimates using the chemical composition of chlorite in the chlorite-

222 quartz-water equilibrium (Vidal et al., 2001, 2005, 2006) either to control RSCM results or

223 to put direct constraints within the shear zones. In parallel, impact of the deformation was

224 evaluated by a combined textural/petrological study of the dated samples and particularly

225 the behaviour of white-micas. Besides, the potential impact of the fluid percolations was

226 evaluated by a careful study of output isotopic ratios. The next sections are dedicated to a

227 brief description of the methods used in this study.

228

229

\subsection{Raman spectrometry of carbonaceous material (RSCM)}

230 The Raman Spectrometry of Carbonaceous Material method (Beyssac et al., 2002) is

231 based on the quantitative study of the degree of graphitization of carbonaceous material

232 (CM), which is a reliable indicator of metamorphic T. Because of the irreversible character

233 of graphitization, CM structure is not sensitive to the retrograde reactions during exhumation

234 and therefore depends on maximum $\mathrm{T}$ (noted Tmax, thereafter) reached during

235 metamorphism (Beyssac et al., 2002). Tmax can be determined in the range $200-650^{\circ} \mathrm{C}$ by

236 using two empirical geothermometers which link the degree of graphitisation measured from

237 Raman Spectra (RS) to the highest temperature ever experienced by the rock (Beyssac et al.,

238 2002; Lahfid et al., 2010). Lahfid et al. (2010) geothermometer was used when the D4

239 defect band was present in the RS, for the low-grade rocks. Absolute precisions of ca. $50^{\circ} \mathrm{C}$

240 between 650 and $300^{\circ} \mathrm{C}$ and ca. $25^{\circ} \mathrm{C}$ between 330 and $200^{\circ} \mathrm{C}$ are related to uncertainties on

241 petrological data used for the calibration. However, relative uncertainties on Tmax appear

242 however much smaller, probably around $10-15^{\circ} \mathrm{C}$ and variations of that order of magnitude

243 may be detected (Beyssac et al., 2004, 2007; Gabalda et al., 2009; Vitale-Brovarone et al.,

244 2013).

245 All Raman spectra were measured and analysed following procedures described in Beyssac

246 et al. (2002, 2004 and 2007) and Lahfid et al. (2010). Raman spectra were obtained using a

247 Renishaw InVIA Reflex microspectrometer (IMPMC, Paris, France) with a $514 \mathrm{~nm}$ argon

248 laser. RSCM analyses were conducted on thin sections prepared on CM-rich metasediments 
249 particularly abundant in the cover series in the studied area, cut in the structural X-Z plane 250 (i.e. orthogonal to foliation and parallel to lineation). To avoid defects on the CM related to 251 thin-section preparation, analyses were all performed below the surface of the section by 252 focusing the laser beam beneath a transparent crystal (i.e. dominantly quartz, calcite, albite

253

254

255

256

257

258

259

260

261

262

263

264

265

266

267

268

269

270

271

272

273

274

275

276

277

278

279

280

281 and occasionally phyllosilicates). Before each session, the spectrometer was calibrated with a silicon standard. 10-20 spectra were routinely recorded for each sample to smooth out the inner structural heterogeneity of CM within samples.

\subsection{Microprobe and independent temperature estimates}

Mineral analyses were performed with a Cameca SX50 electron microprobe (ISTOBRGM, Orléans). Analytic conditions were $15 \mathrm{kV}$ accelerating voltage and $10 \mathrm{nA}$ beam current using Fe2O3 (Fe), MnTiO3 (Mn, Ti), diopside (Mg, Si), CaF2 (F), orthoclase (A1, $\mathrm{K})$, anorthite $(\mathrm{Ca})$, albite $(\mathrm{Na})$ as standards. Elements, which are measured in \%weight of oxide, are $\mathrm{SiO}_{2}, \mathrm{Al}_{2} \mathrm{O}_{3}, \mathrm{Fe}_{2} \mathrm{O}_{3}, \mathrm{MgO}, \mathrm{MnO}, \mathrm{CaO}, \mathrm{Na}_{2} \mathrm{O}, \mathrm{K}_{2} \mathrm{O}, \mathrm{TiO}_{2}, \mathrm{~F}$ and $\mathrm{Cl}$. Chemical composition of chlorite and the white-micas were particularly studied. Composition of chlorite has been used to retrieve independent $\mathrm{T}$ constraints using a thermodynamic approach (Vidal et al., 2001, 2005, 2006). Besides, composition of white-micas was used to distinguish different mineral generations to characterise the dated minerals.

Chlorite, which is abundant in the studied low-grade metamorphic rocks, was used as a geothermometer. Temperatures were estimated by two ways: i) traditional empirical geothermometry based on temperature dependency of the $\mathrm{Si}, \mathrm{Al}$ and vacancy content of the tetrahedral and octahedral sites within chlorite (Cathelineau and Nieva, 1985; Cathelineau, 1988), and ii) a thermodynamical approach (Vidal et al., 2001, 2005, 2006) that integrates multiple substitutions $\left(\mathrm{FeMg}_{-1}, \mathrm{Al}_{\mathrm{IV}} \mathrm{Al}_{\mathrm{VI}} \mathrm{Si}_{-1} \mathrm{Mg}_{-1}, \quad\left(\mathrm{Mg}, \mathrm{Fe}^{2+}\right)_{3 \square_{-1}} \mathrm{Al}_{-2}\right.$ where $\square$ is the vacancy). In the last case, metamorphic temperatures that prevailed during the formation of chlorite were estimated upon 4 equilibria at fixed water activity and pressure $\left(a_{w}=1\right.$ and $\mathrm{P}=4 \mathrm{kbar}$ (Simon-Labric et al., 2009)). Standard deviations are routinely close to $\pm 10^{\circ} \mathrm{C}$ (from $\pm 4^{\circ} \mathrm{C}$ to $\pm 32^{\circ} \mathrm{C}$ ).

\subsection{In situ ${ }^{40} \mathrm{Ar} /{ }^{39} \mathrm{Ar}$ dating}

The ${ }^{40} \mathrm{Ar} /{ }^{39} \mathrm{Ar}$ in situ laser ablation method was first described by Schaeffer et al. (1977) and successively upgraded by York et al. (1981) and Maluski and Monié (1988). Procedure was detailed in Agard et al. (2002), Augier et al. (2005) or Turrillot et al (2011). 
282 We recall here the main stages for ${ }^{40} \mathrm{Ar} /{ }^{39} \mathrm{Ar}$ in situ sample preparation and analytical 283 procedure.

284 Measurements were all performed at Géosciences Montpellier (France) with an analytical system that consists of: (a) an IR- $\mathrm{CO}_{2}$ laser of $100 \mathrm{kHz}$ used at 5-15\% during 60-80 sec; (b) a beam shutter for selection of exposure times; (c) a lenses system for beam focusing; (d) a camera connected to the monitor for beam focusing and selection of ablated zones; (e) a steel chamber with a copper plate and the four samples on. This chamber is depressurized to $10^{-8}$ to $10^{-9}$ bar; (f) an inlet line for purification of gases including two $\mathrm{Zr}$-Al getters; (g) a Argus VI (Thermo-Fisher) multi-collector mass spectrometer from; (h) a software which controls the timing of extraction/purification and the data acquisition. Rock sections of 1 $\mathrm{mm}$ thick, which had been used to make the petrographic thin-sections, were double polished to c. $1 \mu \mathrm{m}$. Whole section and detailed-area photographs of both the rock section and corresponding thin section were taken for an accurate selection of suitable areas for laser experiments. All samples were ultrasonically rinsed in ethanol and distilled water, wrapped in pure aluminium foils and then irradiated in the Triga Mark II nuclear reactor (Pavia, Italia) with several aliquots of the Fisch Canyon sanidine standard $(28.03 \pm 0.08 \mathrm{Ma}$, (Jourdan and Renne, 2007) as flux monitors. After irradiation, both the monitors and the sections were placed on a $\mathrm{Cu}$-holder inside the sample chamber and heated for $48 \mathrm{~h}$ at 150 $200{ }^{\circ} \mathrm{C}$

For each experience, argon was released from a 100 x $300 \mu \mathrm{m}$ mean surface corresponding very often to aggregates of white micas. Incision of the sample did not exceed 10-20 $\mu \mathrm{m}$ depending on the three-dimensional orientation of the white mica crystals. For each experiment, ages have been obtained after correction with blanks, mass discrimination, radioactive decay of ${ }^{37} \mathrm{Ar}$ and ${ }^{36} \mathrm{Ar}$ and irradiation-induced mass interferences. They are reported with $1 \sigma$ uncertainty and were evaluated assuming an atmospheric composition for the initially trapped argon [i.e. $\left({ }^{40} \mathrm{Ar} /{ }^{36} \mathrm{Ar}\right)_{\mathrm{i}}=295.5$ ]. The proportion of ${ }^{38} \mathrm{Ar}$ and ${ }^{37} \mathrm{Ar}$ isotopes that result from interference with chlorine and calcium during irradiation reveals the contribution of $\mathrm{Cl}$ and $\mathrm{Ca}$-rich minerals or inclusions to the overall argon release and so

310 to the calculated age. A blank analysis was done every two or three analyses to evaluate the 311 argon background within the whole analytical system. Isotopic data are computed with the 312 ArArCalc freeware (Koppers, 2002) based on the algorithms described in (York, 1968; 313 Faure, 1986; McDougall and Harrison, 1988; Renne et al., 1998; Min et al., 2000).

314 Along with a strong dependency with temperature and deformation, the behaviour of the $315 \mathrm{~K} / \mathrm{Ar}$ system in white micas can be partially altered by fluid circulations. As fluid 
316 circulations are hardly detected a priori, output isotopic ratios $\left({ }^{36} \mathrm{Ar} /{ }^{39} \mathrm{Ar},{ }^{37} \mathrm{Ar} /{ }^{39} \mathrm{Ar}\right.$ and

$317{ }^{38} \mathrm{Ar} /{ }^{39} \mathrm{Ar}$ ratios) were carefully checked.

318

319

\section{Temperature record within the sedimentary cover}

320

\subsection{A large-scale RSCM Tmax cover in the sedimentary series}

322

\section{First order thermal features}

Our dataset consists of 70 samples collected across the external zones, from Vif to the Penninic Frontal Thrust (E-W transect) and from Saint Jean de Maurienne to Chorges (N-S transect) in various lithologies and all structural units of the studied area except Variscan basement rocks (Table 1, Fig. 4). A more systematic sampling was performed along the E-W transect where the thermal structure is so far poorly documented. Results are all presented in maps of various scales and projected along structure-orthogonal crosssections. For the sake of comparison, results of previous studies including illite-crystallinity maps (Aprahamian, 1974; Barlier et al., 1974) or RSCM data in bounding areas (e.g. Gabalda et al., 2009) are also shown (Fig. 4).

333 At first glance, an unexpected major result of this study is the relative homogeneity of the

334 Tmax value at the scale of study area, with an average value of ca. $330^{\circ} \mathrm{C}(329 \pm 8$ for 27

335 Tmax values along an E-W cross-section), from the Lower Jurassic series close to Vif, all 336 the way to the Galibier pass, at the eastern edge of the study area (Fig. 4, 5). Conversely, lower Tmax ca. $200-220^{\circ} \mathrm{C}$ is recorded to the south either in the Mesozoic series or Eocene flysch (north of Saint Michel de Chaillol; Fig. 4). Moreover, Tmax results recorded further south along an E-W section between Chorges and l'Argentière-la-Bessée (Fig. 4) highlight a drastic southward lateral change in the thermal structure. There, Tmax values present an overall upward temperature increase from $253 \pm 10^{\circ} \mathrm{C}$ to more than $330 \pm 5^{\circ} \mathrm{C}$ in the vicinity of the Penninic Frontal Thrust. Besides, additional important temperature variations were recorded either to the west of the study area (Belledonne and La Mure massifs), to the east in the vicinity of the Penninic Frontal Thrust (Fig. 4, 5). These variations are described here in more details.

348 To the west of the Belledonne and La Mure massifs, Tmax values decrease upward 349 the stratigraphic succession from $334 \pm 6^{\circ} \mathrm{C}-329 \pm 8$ in the Liassic, $325 \pm 6-286 \pm 5^{\circ} \mathrm{C}$ in 
calcareous Dogger and $227 \pm 23-<200^{\circ} \mathrm{C}$ in upper Jurassic black-shales (Fig. 4, 5)

351

352

353

354

355

356

357

358

359

360

361

362

363

364

365

366

367

368

369

370

371

372

373

374

375

376

377

378

379

380

381

382 highlighting a ca. $130^{\circ} \mathrm{C}$ temperature variation. In details, Tmax values gradually decrease sequence along a ca. $30^{\circ} \mathrm{C} / \mathrm{km}$ gradient but also highlight a localised temperature decrease near the top of the calcareous Dogger $\left(296 \pm 5-286 \pm 5^{\circ} \mathrm{C}\right)$ and the base of the upper Jurassic $\left(227 \pm 23-204 \pm 14^{\circ} \mathrm{C}\right)$. This ca. $80^{\circ} \mathrm{C}$ temperature gap can be followed $40 \mathrm{~km}$ strike, which is consistent with a normal sense west-dipping tectonic contact located within the upper Jurassic black-shales (Oxfordian). However, due to poor local outcrop conditions, this contact has not been observed in the field.

In the same area, the base of thick Jurassic sequences of the Vercors yielded Tmax value close to $335^{\circ} \mathrm{C}\left(334 \pm 6^{\circ} \mathrm{C}\right)$ while the thin Jurassic cover of the Belledonne and La Mure massifs yielded only ca. $280^{\circ} \mathrm{C}\left(279 \pm 9^{\circ} \mathrm{C}\right)$. In this case, Tmax distribution evidenced an east-verging shear zone/thrust consistent with the description of a large-scale backthrust in the field by Butler (1989). The Mesozoic sequence of the Vercors therefore appears i) transported eastward above the La Mure thrust which roots in Triassic or Liassic units, and ii) is partly dismembered by an extensional structure (Fig. 4, 5).

\section{Thermal structure in the vicinity of the Penninic Frontal Thrust}

To the east of the study area, close to the Lautaret and Galibier passes, Tmax values decrease gradually from ca. $330^{\circ} \mathrm{C}$ in the easternmost Mesozoic cover of the Oisans Massif to ca. $260^{\circ} \mathrm{C}$ in the Helmintoids flysch (Tête Noire area) despite the presence of numerous tectonic contacts including the PFT. Tmax results therefore align well along an apparent 20$30^{\circ} \mathrm{C} \cdot \mathrm{km}^{-1}$ gradient suggesting either that the Tmax imprint was post-tectonic or that extensional movements are not restricted to the PFT and rather distributed over numerous small-scale, normal-sense structures. In any case, in their current position, Briançonnais units did not experience Tmax higher than ca. $270^{\circ} \mathrm{C}$ which fall well below the ca. $330^{\circ} \mathrm{C}$ temperatures characterising the internal Dauphinois. Conversely, a ca. $40^{\circ} \mathrm{C}$ localized temperature drop is recorded further south, across the PFT (around L'Argentière-la-Bessée, Fig. 4) where the Nummulitic series yielded ca. $330 \pm 5^{\circ} \mathrm{C}$ while Briançonnais units only experienced $291 \pm 6^{\circ} \mathrm{C}$. There, this result is consistent with both field and low-temperature thermochronology evidences of the reactivation of the PFT as an extensional structure (Tricart et al., 2001, 2004, 2006, 2007; Ceriani and Schmid, 2004).

\subsection{Independent temperature record using chlorite geothermometry}


Four samples were selected from the sample collection of the sedimentary cover for

384

385

386

387

388

389

390

391

392

393

394

395

396

397

398

399

400

401

402

403

404

405

406

407

408

409

410

411

412

413

414

415

416 the RSCM approach (see location on Table 2 and on Fig. 2). The main aim of this approach is to estimate the temperature recorded by the cover series using independent geothermometers based on the chemical composition of chlorites (Cathelineau and Nieva, 1985; Cathelineau, 1988; Vidal et al., 2001, 2005, 2006). Results are all presented on figure 6.

Chlorites present different habits and occur in various textures. They are either dispersed in the matrix (samples A-2-2, A-4-232, see location Fig. 2), crystallized within veins (samples A-1-345(2)) or along the foliation and top-to-the-W shear bands (sample A-1-321). Irrespectively to their structural position and to the potential impact of the protolith bulk chemical composition, the two geothermometers yielded quite consistent results for all samples within both the analytical and calibration errors and the within-sample internal dispersion. However, the thermodynamical approach generally yield more dispersed temperature results between ca. 210 and $350^{\circ} \mathrm{C}$ than empirical geothermometry that show an unimodal distribution centrered on the narrow ca. $270-330^{\circ} \mathrm{C}$ range (Fig. 6). Temperature ranging from 150 to $350^{\circ} \mathrm{C}$ was retrieved from sample A.2.2, $150-340^{\circ} \mathrm{C}$ from sample A-4232, $230-380^{\circ} \mathrm{C}$ for sample A-1-321 and $240-390^{\circ} \mathrm{C}$ for sample A-1-345 (Fig. 6). Interestingly, RSCM Tmax fall systematically within the high temperature value indicating i) the cross-validation of the methods and that ii) chlorites, at variance with the RSCM, do record other discrete metamorphic increments. However, textural observations did not allow distinguishing the relative timing of successive chlorite growth events during the metamorphic evolution (prograde or retrograde (re-)equilibrations).

\section{Phyllosilicate habits, chemical composition and chlorite temperature (TChl) record for dated samples}

The crystallisation-deformation relationships of chlorite and white-micas that were first recognised in the field were then strengthened by detailed textural observations in thinsection. Mineral chemical compositions were used to constrain i) the chemistry of dated minerals and ii) the physical conditions by chlorite geothermometry. Together with textural observations, these results are of prime importance to gather accurate a priori constraints and discussion elements for in situ laser-probe investigations. 


\section{5.1 First order common features: guidelines for the ${ }^{40} \mathrm{Ar} /{ }^{39} \mathrm{Ar}$ in situ approach}

At the scale of the outcrop, rocks present routinely large white-mica crystals. Conversely, aggregates of very fine-grained white-micas occur only in deformed zones. At the scale of thin-sections, deformed samples present two contrasted habits of white-micas. Large, up to $2 \mathrm{~mm}$ variously oriented white-mica flakes appear closely associated with a former high-temperature foliation and high-temperature parageneses (Fig. 7). These crystals coexist with aggregates of fine-grained white-micas growing either at the expense of former large crystals or in cracks of various scales within feldspars. Besides, this population presents a close association with deformation structures and particularly with top-to-thewest shear bands within proto-mylonites, mylonites or phyllonites. This strong correlation has been observed at the scale of strain gradients along which large, well-developed whitemica clasts tend to disappear whereas fine-grained blasts form the frame of the rock (Fig. 7). Interestingly, EPMA analyses reveal the existence of two texturally controlled groups of white-mica of contrasted compositions reminding the results of Lanari et al. (2012) in the Briançonnais domain, further east. The first group, which plots close to the muscovite endmember composition, is mainly represented by the large white-micas clasts population carried by an earlier foliation (Fig. 7). Besides, the Na-content of this population is systematically higher than 0.05 a.p.f.u. (atoms per formula unit) while the $\mathrm{Si}$ content is lower than 3.1 a.p.f.u. (Fig. 7). The second group, mostly corresponding to fine-grained aggregates of white-micas, has a phengite chemistry, i.e. between muscovite and celadonite end-member due to Tschermak substitutions. This group presents variable silica-content scattered between 3.2 and 3.6 a.p.f.u. and Na-content systematically lower than 0.05 a.p.f.u. (Fig. 7, 8). However, the small size of crystals and large internal variations of compositions suggest a partial mixing between two end-members.

EPMA analysis of the chemical compositions confirm the presence of two unrelated generations of white-micas recognised on the basis of textural observations and characterized by contrasted chemical compositions. Being conspicuously involved with the greenschist facies partial reequilibration of former high-temperature parageneses and closely associated with a top-to-the-W asymmetry, phengites therefore appear as a synkinematic mineral particularly suitable to put age-constraints on the deformation. Conversely, the 
Besides, temperature, which is the most important factor controlling Argon diffusion,

451

452

453

454

455

456

457

458

459

460

461

462

463

464

465

466

467

468

469

470

471

472

473

474

475

476

477

478

479

480

481

482

must be estimated to make a difference between cooling and deformation (crystallisation) ages. Similarly to temperature estimates performed in the cover series, temperature recorded by basement rocks was estimated using two different chlorite geothermometers. Results are all presented in figure 8 .

\subsection{Textural and chemical characteristics of dated samples}

Following this structural and chemical guideline, white-micas present in the dated samples were carefully studied. Besides, chemical composition of chlorite was used to constrain the temperature experienced by the rocks. Results are all presented from west to east on figure 8 .

\section{Col de Cluy shear zone}

Samples from Col de Cluy are Variscan micaschists and gneisses with greenschist to amphibolite facies associations with quartz, white-micas, feldspar, biotite and/or chlorite. Rocks show generally only an incipient recrystallization. Former biotite and K-feldspar are still preserved and locally abundant. White-micas, which are present in all samples, mostly occur as ca. $1-2 \mathrm{~mm}$ weakly deformed flakes and locally as clasts involved in shear bands. This population coexists with fine-grained white-micas that occur as rare isolated aggregates. Grain-size is generally less than 10 x $50 \mu \mathrm{m}$ and white-mica crystals are often closely associated with chlorite. EPMA analyses of the white-micas mostly plot within a rather narrow composition range close to the muscovite end-member. Analyses of finegrained white-micas plot along continuous pattern from muscovite $(\mathrm{Si}(3.05) ; \mathrm{Na}(0.09 ; 0.12))$ to low-silica content phengite $(\mathrm{Si}(3.15 ; 3.25)$; $\mathrm{Na}(0 ; 0.02))$ (Fig. 8). Chlorite occurs as numerous small-scale aggregates. Chlorite shows variable composition with 70 to $85 \%$ of clinochlore and $\mathrm{XMg}$ values close to 0.45 for variable silica content. Geothermometric results yield quite contrasting results. While the thermodynamic approach yielded dispersed temperature between 150 to $370^{\circ} \mathrm{C}$, empirical geothermometry showed quite consistent ca. 230 to $320^{\circ} \mathrm{C}$ temperature results (Fig. 8). Being devoid of conspicuous Alpine reequilibrations, these samples appear, at a first glance poorly suitable to allow dating the deformation and were therefore not used for the ${ }^{40} \mathrm{Ar} /{ }^{39} \mathrm{Ar}$ in situ approach. 
483

484

485

486

487

488

489

490

491

492

493

494

495

496

497

498

499

500

501

502

503

504

505

506

507

508

509

510

511

512

513

514

515

516

\section{Plan du Lac shear zone}

Thanks to good outcrop conditions allowing the recognition of the strain distribution, the Plan du Lac shear zone was particularly studied. Four samples were selected over the strain gradient. Sample A-4-74b is a proto-mylonite sample showing a rather weak Alpine deformation by comparison to samples A-4-68 and 68b that are phyllonites. Sample A-4-66b was selected from an intermediate position within the strain gradient. All samples show a clear top-to-the-west asymmetry except sample A-4-66b picked along a localized top-to-theE shear zone.

All samples derive from a quartz, feldspar, biotite and white mica Variscan gneiss. Chlorite pervasively replaces biotite either as static pseudomorphs in low strain domains or as synkinematic crystallisations in mylonites. In low strain domain, white mica occur as large, up to ca. 1-2mm clasts with clear disequilibrium textures while fine-grained whitemica are rare and clearly secondary. Conversely, mylonite and phyllonite are almost devoid of large clasts and exclusively made of fine-grained white-micas. EPMA composition of white-micas reveals two distinct poles with very few intermediate values (Fig. 8). The first pole that corresponds to muscovite $(\mathrm{Si}(3.15) ; \mathrm{Na}(0.06 ; 0.08))$ and the second one to a silicarich phengite $(\mathrm{Si}(3.2 ; 3.4) ; \mathrm{Na}(0 ; 0.02))$ (Fig. 8). Interestingly, mineral composition shows a conspicuous dependency to deformation. Mylonite and phyllonite samples yield mostly phengitic white-micas. Conversely, less-deformed proto-mylonite sample yield texturallycontrolled chemical compositions with muscovite compositions for the large clasts and phengite composition for the fine-grained blasts.

Chlorite is locally abundant. It occurs in the matrix, growing at the expense of biotite, crystallized in syn-deformation veins or associated with fine-grained white-micas along shear planes. Most analyses yield consistent results with 70 to $90 \%$ of clinochlore content, an XMg close to 0.45 for a variable silica content (Fig. 8). Regardless of strain intensity, structural position and habits, most results cluster between 260 to $290^{\circ} \mathrm{C}$ (Fig. 8).

\section{Col du Lac shear zone}

Sample A-1-355 was collected from the core of a top-to-the-W shear band characterized by a thin layer of phengite-quartz phyllonites. This sample derives from a Variscan high-grade gneiss still preserved a few decimetres apart on the same outcrop. The rock is made of quartz, feldspar and biotite partly turned into chlorite. Interestingly, white 
517 mica is absent from the mineralogical composition of the protolith. Small-scale but abundant

518 white-mica aggregates from the phyllonites are therefore newly-crystallized as the result of

519 strain and/or fluid-induced destabilization of the K-feldspar (e.g. Gueydan et al., 2003).

520 Accordingly, EPMA analyses of the white-micas all yielded phengitic compositions with a 521 very low dispersion $(\mathrm{Si}(3.2 ; 3.4) ; \mathrm{Na}(0 ; 0.02))$.

522 Chlorite occurs as small-scale aggregates and rare dispersed larger crystals that may derive 523 from former biotites. Chlorite shows almost constant composition close to the clinochlore 524 end-member with XMg values around 0.6. Most geothermometric results cluster between 525250 and $290^{\circ} \mathrm{C}$ for both geothermometers (Fig. 8).

526

\section{Combeynot shear zone}

528

529

530

531

532

533

534

535

536

537

538

539

540

541

542

543

544

545

546

547

548

549

550

Sample A-1-345 was selected in the most deformed outcropping ductily-deformed basement rocks of the Combeynot shear zone. Mylonites are scarce and proto-mynolites, derived from orthogneiss, which belongs to a volcano-sedimentary complex (Barbier et al., 1973), are often directly overthrusted onto the sedimentary cover. White micas occur generally as large clasts surrounded by very fine-grained blasts. Aggregates of fine-grained white-micas also occur in tension gashes in K-feldspar. Composition of white-micas shows a rather continuous pattern from muscovite $(\mathrm{Si}(3.05 ; 3.15)$; $\mathrm{Na}(0.06 ; 0.08)$ ) to phengite $(\mathrm{Si}(3.25 ; 3.5) ; \mathrm{Na}(0 ; 0.02))$ (Fig. 8). Despite a clear partially reequilibration within Alpine physico-chemical conditions, Alpine white-micas occur as very fine grained aggregates.

Chlorite is rare, small and often closely associated with white-micas. Thus, most chlorites show mixed composition with white-micas (i.e. K-rich chlorite) and were thus discarded.

Data are thus only presented in table 2 .

Synkinematic fine-grained aggregates of phengite appear particularly adapted to put age-constraints on the activity of the shear zones. Accordingly, samples from Col de Cluy shear zone which may record only a weak Alpine re-equilibration have not been selected from the in situ ${ }^{39} \mathrm{Ar} /{ }^{40} \mathrm{Ar}$ approach. For all other samples, success of the study relies on our ability to effectively analyze newly formed crystals whose typical size is often small $(150 \mu \mathrm{m}$ $\max$.$) .$

Temperatures recorded in the shear zones yielded very consistent results close to $250-300^{\circ} \mathrm{C}$ which falls below RSCM Tmax recorded in the cover series. Chlorite therefore probably recorded retrograde metamorphic increments during exhumation and cooling of the Oisans 
551 Massif. It is noteworthy that temperatures recorded at peak-T conditions also fall below the

552 lower bound of the closure temperature of white-micas (e.g. Dodson, 1973; Cliff et al., 553 1998; Villa, 1998).

554

555

$6{ }^{40} \mathrm{Ar} /{ }^{39} \mathrm{Ar}$ age constraints

556

Our dataset consists of 199 in situ ${ }^{40} \mathrm{Ar} /{ }^{39} \mathrm{Ar}$ ages performed on 7 samples collected over three main Alpine shear zones, namely (from west to east), the Plan du Lac, Col du Lac, and the Combeynot shear zones (Table 3, see location on Fig. 2). To ensure the coverage of the different strain facies recognized in the field, a more systematic sampling was performed over the Plan du Lac shear zone. Results of the in situ ${ }^{40} \mathrm{Ar} /{ }^{39} \mathrm{Ar}$ approach are all shown and discussed in Fig. 9 as apparent ages for which an initial ${ }^{40} \mathrm{Ar} /{ }^{39} \mathrm{Ar}$ ratio of 295.5 is assumed for the non-radiogenic argon component. These age results are described in the light of the textural/structural observations, chemical composition results and the output isotopic ratios $\left({ }^{36} \mathrm{Ar} /{ }^{39} \mathrm{Ar},{ }^{37} \mathrm{Ar} /{ }^{39} \mathrm{Ar}\right.$ and $\left.{ }^{38} \mathrm{Ar} /{ }^{39} \mathrm{Ar}\right)$ informative of potential disturbances of the K/Ar system. For small-scale phengite aggregates located in the vicinity of chlorite, calcium or fluid inclusions-bearing minerals, the release of the ${ }^{38} \mathrm{Ar}$ and ${ }^{37} \mathrm{Ar}$ isotopes interfering with chlorine and calcium revealed that argon was extracted from both phengites and K-poor minerals (Brereton, 1970; McDougall \& Harrison, 1988). The quoted errors represent one sigma deviation and do not include uncertainty on the monitor. Errors are routinely inferior to ca. $1 \mathrm{Ma}$ while larger error (ca. 2 to $15 \mathrm{Ma}$ ) are generally due to both a weak argon signal and a high atmospheric contribution (Table 3).

572

At a first glance, an important conclusion is that the successive phengite generations recognized on the basis of textures (e.g. Fig. 7), compositions (Figs 8) effectively yield successive ages. Fine-grained aggregates of synkinematic phengites yield Alpine ages sensu lato. Conversely, white-micas characterized by muscovite chemical compositions and/or presenting clear pre-kinematic (i.e. inherited) habits yielded pre-alpine ages or even sometimes Variscan ages. Interestingly, a clear dependency to the intensity of the deformation may even be detected either at the scale of the sample or at the scale of the strain gradient within a shear zone (e.g. Fig. 10). Therefore, most ages are tentatively interpreted either as, at least partially, re-opened Variscan isotopic systems for "old" ages or as genuine crystallization ages for the "young" ca. 35-25 Ma ages. More locally, results however show important age variations that may also record fluid percolations.

\subsection{Plan du Lac shear zone}


In order to study the potential impact of the finite Alpine deformation, four samples

586

587

588

589

590

591

592

593

594

595

596

597

598

599

600

601

602

603

604

605

606

607

608

609

610

611

612

613

614

615

616

617 were selected over a single strain gradient toward the core of the Plan du Lac shear zone. The relative structural position of samples is given on figure 10 .

\section{A-4-74b (Proto-mylonite)}

In this sample, discrete ca. 1mm-thick shear bands partially overprint a hightemperature inherited texture composed by large, brittlely fractured feldspar clasts and more ductilely stretched quartz and muscovite crystals (Fig. 10). Conversely, this sample contains Alpine phyllosilicates including phengite and chlorite either carried along a weak vertical foliation, or crystallized along top-to-the-W shear bands. A total of 40 apparent in situ analyses were performed to cover all situations. Apparent in situ ages are scattered between $207 \pm 5.2 \mathrm{Ma}$ and $24.3 \pm 1.8 \mathrm{Ma}$ (Fig. 10). 22 analyses corresponding to the oldest ages are correlated with high ${ }^{38} \mathrm{Ar} /{ }^{39} \mathrm{Ar}$ ratio and atmospheric content (Table 3) but ages fall within the age range of uncontaminated phengites. Interestingly, the core of the shear bands provides ca. $25 \mathrm{Ma}$ consistent ages $(24.3 \pm 1.8 \mathrm{Ma}$ and $26.7 \pm 0.6 \mathrm{Ma})$.

\section{A-4-66b (Top-to-the-E Mylonite)}

This sample is characterized by a schistosed high-grade gneiss traversed by a $3 \mathrm{~mm}$ thick top-to-the-E shear band (Fig. 10). While Variscan fabrics are still well developed in most of the rock volume, Alpine synkinematic recrystallizations are almost complete within shear bands. There, former muscovites and feldspars are absent and a ca. $2 \mathrm{~mm}$ thick phengitized fringe is developed (Fig. 10). 34 in situ analyses were performed. No relationship between apparent ages and the ${ }^{37} \mathrm{Ar} /{ }^{39} \mathrm{Ar}$ and ${ }^{38} \mathrm{Ar} /{ }^{39} \mathrm{Ar}$ variations were detected, except for the 3 three apparent ages older than ca. 100Ma, which have high ${ }^{38} \mathrm{Ar} /{ }^{39} \mathrm{Ar}$ values (Table 3). Analyses show a first order textural control of the age. Large muscovites, at least partially preserved within the matrix yielded $301.4 \pm 6.6$ and $62.3 \pm 1.4 \mathrm{Ma}$. Conversely, small-scale phengites within the shear band yielded 30 alpine ages ranging between $40.5 \pm$ 1.1 Ma and 29.5 $\pm 0.6 \mathrm{Ma}$ plus an older age of 47.6 $\pm 1.2 \mathrm{Ma}$ (Fig. 10). Interestingly, while ages depict a clear first order younging toward and within the shear band, older ages occur within the core of the shear band over a ca. 1-2mm-thick fringe (Fig. 10). In this case, a late gradient of ${ }^{40} \mathrm{Ar}$ excess seems to overprint an initial age gradient related to deformation.

\section{A-4-68 (Phyllonite)}


Sample A-4-68 is a phyllonite sample. 15 in situ analyses were performed and yielded ages ranging between $93.5 \pm 2.0$ and $22.4 \pm 0.9 \mathrm{Ma}$ (Table 3). Most of apparent ages cluster between 32 and $22 \mathrm{Ma}$ (Fig. 10). There is no relationship of apparent ages with ${ }^{37} \mathrm{Ar} /{ }^{39} \mathrm{Ar}$ unlike with ${ }^{38} \mathrm{Ar} /{ }^{39} \mathrm{Ar}$, suggesting some interaction with chlorine-rich fluids that may occur as trapped inclusions (Fig. 10).

623

A-4-68b (Phyllonite)

Sample A-4-68b was cut in two distinct rock slabs (section 8 and 5) selected only a few centimeters distant; section 5 being a little less deformed than section 8 . Analyses performed on section 5 yielded 21 apparent ages, ranging between $114.2 \pm 4.3$ and $25.9 \pm$ $0.5 \mathrm{Ma}$ (Fig. 10). Analyses present a strong relationship between apparent ages and ${ }^{37} \mathrm{Ar} /{ }^{39} \mathrm{Ar},{ }^{38} \mathrm{Ar} /{ }^{39} \mathrm{Ar}$ and atmospheric content. In the absence of Ca-rich and Cl-rich phases in the chip, contamination may be rather related with fluid inclusions trapped in the analysed phengites (Table 3). Despite contamination by Ca-rich and Cl-rich fluids, analyses yielded ages of about 25-27 Ma. Interestingly, analyses performed on section 8 yielded 44 apparent ages, which do not show any evidence of a direct relationship with the ${ }^{37} \mathrm{Ar} /{ }^{39} \mathrm{Ar},{ }^{38} \mathrm{Ar} /{ }^{39} \mathrm{Ar}$ and atmospheric content. These ages are scattered between $37.2 \pm 1.0 \mathrm{Ma}$ and $23.2 \pm 0.6 \mathrm{Ma}$ (with two old ages of 46.4 and 47.2 Ma) and define mainly two age groups at 31-33 Ma (7 ages) and 25-27 Ma (18 ages) (Fig. 10).

637

6.2 Col du Lac shear zone (Sample A-1-355, phyllonites)

639

Sample A-1-355 was collected from the core of a top-to-the-W shear band characterized by a ca. 1 meter-thick layer of phyllonites. This sample derives from a

641 Variscan high-grade gneiss still preserved a few decimetres apart on the same outcrop and 642 turned into a phengite-quartz rock in the most deformed zone. It contains few chlorites and 643 no remnant of inherited muscovites present in the undeformed protolith. The 30 apparent 644 ages are scattered between $110 \pm 7 \mathrm{Ma}$ and $15 \pm 10 \mathrm{Ma}$ and 25 of them range between 42.68 $645 \pm 2.22$ and $23.88 \pm 1.6 \mathrm{Ma}$ (Table 3 ). No correlation between the apparent age and ${ }^{38} \mathrm{Ar} /{ }^{39} \mathrm{Ar}$ 646 and ${ }^{37} \mathrm{Ar} /{ }^{39} \mathrm{Ar}$ ratios was observed. However, some analyses, particularly the "old", up to 50 647 Ma ages present high ${ }^{38} \mathrm{Ar} /{ }^{39} \mathrm{Ar}$ values and/or an important atmospheric contribution (Table 648 3). Interestingly, these old ages were found in micas from $C^{\prime}$-type shear bands and therefore 649 argue for a ${ }^{40} \mathrm{Ar}$ excess. These results are quite similar to those obtained in the most 650 deformed parts of sample A-4-66b. Despite this potential contamination, analyses with low 
651

652

653

654

655

656

657

658

659

660

661

662

663

664

665

666

667

668

669

670

671

672

673

674

675

676

677

678

679

680

681

682

683

${ }^{38} \mathrm{Ar} /{ }^{39} \mathrm{Ar}$ ratio and low atmospheric content yielded 15 internally consistent apparent ages scattered between $32.9 \pm 0.9$ and $24.8 \pm 0.6 \mathrm{Ma}$ (Fig. 10).

\subsection{Combeynot shear zone (Sample A-1-345, proto-mylonite)}

Sample A-1-345 was selected in the most deformed outcropping ductilely-deformed basement rocks of the Combeynot shear zone. Mylonites are scarce and protomylonites, derived at the expense of orthogneiss (former leucogranite) are often directly overthrusted onto the sedimentary cover. It is the less deformed sample of the data set. None of the 15 in situ analyses provide Alpine age (Table 3, Fig. 10). Instead, apparent ages are distributed between $389 \pm 27 \mathrm{Ma}$ and $156 \pm 3 \mathrm{Ma}$ with no clear textural control. Part of the apparent ages is correlated with the ${ }^{38} \mathrm{Ar} /{ }^{39} \mathrm{Ar}$ ratio, which suggests a possible contribution of Cl-rich phases or fluid inclusions. High ${ }^{37} \mathrm{Ar} /{ }^{39} \mathrm{Ar}$ ratios (Table 3 ) are probably due to the degassing of Variscan epidote or titanite, but again no systematic correlation between the variation of these ratios and the age dispersion was observed.

\section{Discussion}

\subsection{Reliability, significance of the RSCM Tmax mapping}

RSCM Tmax estimates has proven an efficient mean to put extensive temperature constraints on the thermal structure of coherent units or on the importance of tectonic contacts (Beyssac et al., 2002; Augier et al., 2005; Negro et al., 2006; Gabalda et al., 2009; Angiboust et al., 2011). In the Oisans Massif, RSCM Tmax fall in the same temperature range as more punctual results issued from other methods available in literature. The most important result is the uniformity of Tmax values at the scale of study area, with an average value of ca. $330^{\circ} \mathrm{C}$ with a relative error that may not exceed $10-15^{\circ} \mathrm{C}$ (Beyssac et al., 2004). Thermopaleomagnetic studies indicate that cooling started from $335^{\circ} \mathrm{C}$ in the north of the Emparis formations and in the Bourg d'Oisans basin, after the main tectonic phase at ca. 25 Ma (Ménard and Rochette, 1992; Crouzet et al., 1999, 2001) (Fig. 11). The stability field of paragenesis observed in the Jurassic cover (quartz-cookeite-margarite-pyrophyllite) that most likely recorded peak-metamorphism conditions in the Emparis basin is restricted from 270 to $340^{\circ} \mathrm{C}$ and from 1 to 5kbar (Jullien and Goffé, 1993) (Fig. 11). Besides, the overall 
684 thermal structure of the Oisans Massif as recorded by the distribution of RSCM Tmax is 685 consistent with illite-crystallinity maps (Aprahamian, 1974; 1988; Barlier et al., 1974) (Fig. $6864)$.

687 Related to the irreversible character of graphitization, and the insensitivity of the CM structure to retrograde reactions (e.g. Beyssac et al., 2002; Lahfid et al., 2010; Aoya et al., 2010), RSCM record the highest temperature ever undergone by the rock sample. In principle, RSCM Tmax results issued from a continuous section may therefore be diachronous and represent the superimposition of distinct thermal events.

692 In the Bourg d'Oisans and Emparis basins, metamorphic peak-T conditions of ca. $335^{\circ} \mathrm{C}$ 693 where reached at ca. 25 Ma (i.e. Crouzet et al., 1999, 2001). As the restored sedimentary 694 cover of this area is generally thinner than ca. $2 \mathrm{~km}$ (Barféty et al., 1972; Barbier et al., 695 1973; Crouzet et al., 2001; Bellahsen et al., 2012), these temperatures are clearly ascribed to 696 an Alpine tectonometamorphic event and particularly to the tectonic burial of the 697 Dauphinois domain under internal units (Crouzet et al. 2001; Dumont et al., 2008). Besides, 698 the progressive temperature decrease toward the top of the overthrusting units close to the 699 Galibier pass is consistent with a late to post-tectonic temperature imprint, as suggested by 700 thermopaleomagnetic results (Crouzet et al., 1999, 2000). Interestingly, the upward RSCM 701 Tmax evolution indicates a ca. $20-30^{\circ} \mathrm{C} \cdot \mathrm{km}^{-1}$ gradient (Fig. 4C), which is consistent with the 702 gradient around 20 to $25^{\circ} \mathrm{C} \cdot \mathrm{km}^{-1}$ proposed by Crouzet et al. (1999) but lower than the ca. 40$70350^{\circ}{\mathrm{C} . \mathrm{km}^{-1}}$ gradient deduced from fluid inclusion data (Gratier et al., 1973; Nziengui, 1993) 704 (Fig. 12). However, high geothermal gradients deduced from fluid inclusions may result 705 from an underestimated pressure due to reequilibriation of fluid inclusion densities during an isothermal decompression as proposed by Boullier (1999) or Crouzet et al. (2001).

707 Conversely, in the sedimentary cover west of the Belledonne Massif, Tmax values show 708 large temperature variations from $335^{\circ} \mathrm{C}$ to less than $200^{\circ} \mathrm{C}$ (Fig. 4, 5). Tilted with the 709 bedding, this ca. $130^{\circ} \mathrm{C}$ Tmax upward sequence decrease may witness a post-metamorphic 710 peak westward tilting of the sedimentary succession (Fig. 4, 5). Moreover, Tmax recorded at 711 the base of the succession is consistent with the ca. $8 \mathrm{~km}$ thickness of the Mesozoic series 712 assuming a ca. $40^{\circ} \mathrm{C} \cdot \mathrm{km}^{-1}$ geothermal gradient (Philippe et al., 1998). Besides, this result is 713 consistent with the 60 to $80 \mathrm{~mW} \cdot \mathrm{m}^{-2}$ basal heat flow estimated in this area (Deville and 714 Sassi, 2006) and a bulk thermal conductivity close to $1.5 \mathrm{~W} \cdot \mathrm{m}^{-1} \cdot \mathrm{K}^{-1}$ (Beardsmore and Cull, 715 2001).

716 Minor and local fluid circulations along the basement-cover interface cannot be ruled out 717 but an overall thermal imprint related to large-scale fluid circulations is unlikely as available 
studies show that the fluid flow operated only at small scale in the studied area (Henry et al., 1996; Kirschner et al., 1999; Boutoux et al., 2014b).

\subsection{Significance of the ${ }^{40} \mathrm{Ar} /{ }^{39} \mathrm{Ar}$ in situ ages}

Geochronological data and particularly ${ }^{40} \mathrm{Ar} /{ }^{39} \mathrm{Ar}$ data are traditionally interpreted as recording closure of the isotopic system at a specific temperature depending on the isotopic diffusion properties of the mineral (e.g. Dodson, 1973; Cliff et al., 1998; Villa, 1998; Harrison et al., 2009). Accordingly, many studies therefore assume that the closure temperature of the K/Ar system for muscovite argon retention is around $350-450^{\circ} \mathrm{C}$ depending on cooling-rates, grain-size and other controlling factors such as the geometry of the diffusion domain (e.g. Wijbrans \& McDougall, 1986; Hames \& Bowring, 1994; Reddy et al., 1996; Villa, 1998). Using recent results of modeling, the closure temperature for muscovite would fall in the range of $400-420^{\circ} \mathrm{C}$ for a $10-30^{\circ} \mathrm{C}^{-\mathrm{Ma}^{-1}}$ cooling-rate and a diffusion radius of $100 \mu \mathrm{m}$ (Harrison et al., 2009). However, closure temperature for phengite is still discussed as it may largely vary as a function of both intrinsic (e.g. grainsize) and extrinsic (cooling-rates, temperature, pressure and deformation or fluid circulations) parameters. Recent studies suggest that phengite is more retentive for argon than muscovite and that phengite ages are interpretable as crystallisation ages to temperature as high as $500-550^{\circ} \mathrm{C}$ (e.g. Dunlap, 1997; Agard et al., 2002; Müller, 2003; Mulch and Cosca, 2004; Augier et al., 2005; Mulch et al., 2005; Gerber, 2008; Rolland et al., 2008, 2009; Sanchez et al., 2011a). Temperature experienced during the Alpine orogeny by dated samples did not exceeded $330^{\circ} \mathrm{C} \pm 30^{\circ} \mathrm{C}$ since they initially cooled at the end of the Variscan Orogeny. Ages of the fine-grained synkinematic phengites therefore likely represent crystallization ages. Conversely, large, inherited clasts of muscovite may reflect Variscan cooling ages in the absence of additional disturbing factors. Stratigraphic constraints indicate that the flexural basin of the external zones was diachronously filled up from Lutetian to Bartonian (45 to 33Ma) (Du Fornel et al., 2004; Mulder et al., 2010; Salles et al., 2011). Burial of this basin below internal units occurred during Rupelian (34 to 28 Ma; Fry, 1989; Sinclair, 1997; Ford and Lickorish, 2004; Mulder et al., 2010). In Champsaur and Saint-Antonin basins, amphiboles reworked from Oligocene volcanism coeval with deposition yielded ca. 34-31 Ma Priabonian ages by ${ }^{40} \mathrm{Ar} /{ }^{39} \mathrm{Ar}$ methods (Féraud et al., 1995; Ivaldi et al. 2003), giving a maximum age for the burial of the basins under the 
751 internal nappes. In addition, part of the Oisans Massif formed a $500 \mathrm{~m}$ high relief in the 752 Oligocene (Gupta and Allen, 2000) and dated samples, restored in their inferred initial 753 position, were probably less than $2 \mathrm{~km}$ deep, between ca. 40 and $34 \mathrm{Ma}$. It therefore appears 754 unlikely that phengites were formed under these P-T conditions and the ca. 34-33 Ma age 755 clearly fixes the upper bound of the possible ages for the deformation of the Oisans Massif. 97 in situ experiments yielded ages younger than 34 Ma.

757 Interestingly, young ages are clearly correlated with the intensity of fine-grained white758 micas blastesis particularly important in high-strain zones. It is therefore proposed that ages 759 younger than $34 \mathrm{Ma}$ reflect synkinematic crystallisation ages and thus deformation ages, in a 760 broad sense. In addition, apparent ages show a bimodal distribution with a first age group 761 settled at ca. 33-30 Ma and a second group at ca. 28-25 Ma ages (Fig. 11). These results are 762 consistent with results of a conventional ${ }^{40} \mathrm{Ar} /{ }^{39} \mathrm{Ar}$ approach performed on wrench shear 763 zones of the same area (Simon-Labric et al., 2009). However, our interpretation differs.

764 Based on age spectra scattered between 32 and 24 Ma, Simon-Labric et al. (2009) proposed 765 the superimposition of two distinctive shearing events (one at ca. 32 and one ca. $24 \mathrm{Ma}$ ). In 766 this study, the use of an in situ mean over strain gradients allow linking deformation ages 767 and the amount of finite strain experienced by the rocks. Accordingly, proto-mylonite and 768 mylonite samples yielded older, ca. 33-30Ma ages while highly strained samples 769 (phyllonites) yielded younger ca. 28-25 Ma ages, suggesting that the deformation 770 progressively localized along the phyllonite bands thus leaving large rock volumes devoid of 771 further recrystallizations. In any case, intense E-W shortening started with or just after the burial of external zones under the internal nappes around ca. 34-33 Ma and was still active at ca. 25 Ma. Synchronous deformation ages of either top-to-the-W reverse shear zones or wrench shear zones thus confirm the small-scale mutual cross-cutting relationships observed in the field (Bellanger et al., 2014).

776102 in situ experiments yielded ages mostly clustering between 100 and $40 \mathrm{Ma}$ with ages as 777 old as $380 \mathrm{Ma}$. Older than ca. $34 \mathrm{Ma}$ and presenting sometimes pre-Alpine or even genuine 778 Variscan ages, theses apparent ages clearly do not record alpine collisional deformation. 779 Relying on temperature estimates throughout the studied area, the temperature concept 780 predicts that all white-micas sharing common pre-Alpine textures and inherited muscovite 781 chemical composition should yield the same age corresponding to the time elapsed since 782 initial cooling at the end of the Variscan Orogeny. Yet this is not the case for most analyses. 783 On the contrary, the correlation of in situ ${ }^{40} \mathrm{Ar} /{ }^{39} \mathrm{Ar}$ ages and finite strain intensity at any 784 scale reveals that ages are texturally-controlled and therefore independent of closure 
temperature. This deviation to the closure temperature concept could be simply explained in terms of presence of ${ }^{40} \mathrm{Ar}$ excess either due to (1) partial deformation-induced resetting of Variscan muscovites (inherited argon), or (2) genuine incorporation of extraneous argon related to fluid circulations. Besides, a straightforward yet possible source of geologically meaningless ages could be simply explained by mixtures between inherited muscovite and synkinematic phengite argon reservoirs during lasering.

At first glance, as stated above, an overall correlation with the intensity of the finite strain can be drawn between samples. Weakly strained samples (from the Combeynot or the Plan du Lac shear zones) yielded rather old, sometime only pre-Alpine ages while phyllonites yielded much younger ages that tend to crystallization ages of newly formed crystals. Such control by the deformation is also perceptible at the scale of some dated rock samples with an overall age decrease toward the core of a shear band from ca. $300 \mathrm{Ma}$ to less than $30 \mathrm{Ma}$ in less than 1 centimetre (Fig. 11). It appears therefore tempting to ascribe to deformation the ability to facilitate argon diffusion and thus to partially reset (i.e. re-open) inherited muscovite isotopic system. Intensity of deformation, whether it occurs by grain-size reduction during mylonitization or by presence and distribution of high-diffusivity pathways lattice-modifying microstructures would therefore be the main controlling factor explaining the age scatter between an inherited cooling ages and the age of a tectonometamorphic event (i.e. Scaillet et al., 1990; West and Lux, 1993; Hames \& Cheney 1997; Kramar et al. 2001, 2003; Mulch et al. 2002). As suggested by the linear relationships observed between some apparent ages and corresponding ${ }^{38} \mathrm{Ar} /{ }^{39} \mathrm{Ar}$ ratios arguing for interactions with $\mathrm{Cl}$-rich fluids, minor excess argon cannot be simply ruled out. Besides, a limited yet conspicuous input of extraneous argon within and in the vicinity of shear bands is clearly detectable for some samples (Fig. 10). In this case, results of absolute chronology are markedly inconsistent with the relative chronology established independently on the basis of microtextures. For example, mylonite sample A-4-66b presents a series of ca. 50-40 Ma old ages occurring within the core of the shear band while other analyses show a clear age decrease toward the shear band. Excess argon was moreover reported within fluid inclusions from Oisans basement quartz veins (Nziengui, 1993). In this study seven K/Ar experiments on whitemicas from the sedimentary cover yielding initially 48 to 30 Ma ages were corrected to $27-$ $23 \mathrm{Ma}$ by removing excess ${ }^{40} \mathrm{Ar}$ content from fluid inclusions. If excess argon exists, it should have a homogeneous composition at the scale of the whole study area, which seems particularly unlikely. Excess argon is therefore present but does not explain the first order features of the results. 


\subsection{A new tectonic scenario}

823

This study brings primarily T-t-d (Temperature-time-deformation) results that further constrain the tectonometamorphic evolution of the external zones of the Western Alps. In

826 this section, these results are all integrated into a compilation of published P-T-t-d results

827 (Fig. 11 and 12) in order to discuss a new tectonic scenario (see also in Bellahsen et al., 828 2014) (Fig. 13).

829 Among the new results, this study constrains the thermal structure of a large volume of the 830 external basement. Results, despite local variations, show a constant Tmax around $330^{\circ} \mathrm{C}$.

831 This constant temperature along several tens of kilometres suggests that the basement and 832 the cover preserved in half-grabens have been first quickly underthrust with rather limited 833 internal shortening. Deformation ages from this study and from Simon-Labric et al. (2009)

834 are consistent with a burial of the external zones around between 34 and $25 \mathrm{Ma}$ (Fig. 12, 835 13). The main shortening seems to have occurred at or around the metamorphic peak (Fig. 836 12) as suggested in Boutoux et al. (2014b). The distribution of isotherms obtained with 837 thermopaleomagnetic method, which cross-cut the folds, indicates that the main shortening 838 had ended before cooling started in the Bourg d'Oisans basin (Crouzet et al., 1999). The 839 sampled profile may therefore correspond to an east-dipping isotherm (around $330^{\circ} \mathrm{C}$ ) 840 during underthrusting of the Oisans Massif, which would then suggest that the whole area 841 behaved as a more or less rigid block below the internal units during part of its burial 842 history, before it was ultimately shortened. Similarly, the geothermal gradient observed 843 close to the Lautaret and Galibier passes (around $20-30^{\circ} \mathrm{C}_{\mathrm{km}} \mathrm{km}^{-1}$ ) seems to seal the PFT 844 activity dated between 32 and 27 Ma (Freeman, 1998). Thus, deformation mainly occured 845 just prior or during metamorphic-peak conditions and seems, in any case, to have ceased 846 before the onset of the main cooling event. During this time period, and around the 847 metamorphic peak conditions, the external zone crust underwent homogeneous shortening 848 until approximately $25 \mathrm{Ma}$. Shortening was progressively localized into phyllonite bands. At $84925 \mathrm{Ma}$, the crust was progressively decoupled from the subducting lithosphere and started to 850 exhume. The PFT was then inactivated. These results argue against a progressive westward 851 thrust slice development that lead to the exhumation of units after that they have reached 
852 diachronously temperatures close to $330^{\circ} \mathrm{C}$. However, this would imply that the basement

853 top has been heated up uniformly from $50-100^{\circ} \mathrm{C}$ to $300-350^{\circ} \mathrm{C}$ uniformly over ca. $70 \mathrm{~km}$, 854 which in turn suggests a rather slow burial.

855 At the scale of individual shear zones, high-strain samples (phyllonite) are younger 856 (28-25Ma) than proto-mylonite and mylonite (33-30Ma). This suggests that deformation 857 progressively localized along phyllonite bands. Moreover, ages of deformation (33-25 Ma) 858 reveal that the deformation is contemporaneous all along the profile from the PFT to the 859 Plan du Lac shear zone, i.e. over more than ca. $30 \mathrm{~km}$. This synchronicity of deformation 860 shows that shortening in the ECM was distributed in space and time and confirms that the 861 crust was relatively weak during shortening as proposed in Bellahsen et al. (2012). This is in 862 agreement with the formation of newly formed shear zones rather than normal faults 863 reactivation.

864 Later, shortening reached the Vercors fold and thrust belt during Burdigalian to 865 Langhian times (Fig. 13). This shortening appears linked to crustal ramps below the 866 Belledonne Massif, which suggests that the deformation localized in frontal parts after the 867 end of the main shortening phase of the ECM at around $20 \mathrm{Ma}$ (Ménard, 1979; Butler, 1989; 868 Philippe et al., 1998). Between 25 and $20 \mathrm{Ma}$, the Oisans Massif has undergone fast cooling 869 at a rate of $33^{\circ} \mathrm{C} \cdot \mathrm{Ma}^{-1}$ (Crouzet et al., 2001) and was exhumed at a rate of $0.4 \mathrm{~km} \cdot \mathrm{Ma}^{-1}$ (van 870 der Beek et al., 2010). Final cooling, whose age is estimated from fission tracks ages 871 (Vernon et al., 2008), occurred after $15 \mathrm{Ma}$, which corresponds to the age of thrusting within 872 the Vercors Massif. During this more external fold and thrust belt shortening, only slight 873 deformation occurred in the Oisans Massif (Dumont et al., 2008). The new argon data 874 reported here thus complete the scenario of burial and first shortening at ca. 33 Ma, 875 progressive localisation of shear zones until $25 \mathrm{Ma}$, and final exhumation above a crustal 876 ramp until after 15-20 Ma.

877 Exhumation of the ECM was also accompanied by extensional reactivation of the PFT since 878 the late Oligocene (Tricart et al., 2007) (Fig. 13). Thus, during the late Oligocene and early 879 Miocene, the ECM was a crustal unit bordered by a normal fault to the east and a reverse 880 fault to the west, transported with low internal deformation, similarly to the models of syn881 collisional rock exhumation described by Chemenda et al. (1995) (Fig. 14). Moreover, 882 numerous veins witnessing for fluids circulation have been documented between 17 to $5 \mathrm{Ma}$ 883 in the Aar Massif (Mullis et al., 1994; Mullis, 1996; Challandes et al., 2008), in the Mont 884 Blanc Massif (Leutwein et al., 1970; Marshall et al., 1998) or in the Belledonne Massif 
885 (Gasquet et al., 2010), indicating that this event was coeval with a fluid-rich process which

886 affected all the orogen.

887

888

\section{Conclusion}

889

890

Following the description of Alpine shear zones responsible for shortening of the 891 Oisans External Massif of the Western Alps by Bellahsen et al. (2012) and Bellanger et al. 892 (2014), the alpine thermal structure of the massif is established here thanks to the RSCM 893 method and the shear zones were dated. The main outcome is that the interface between the 894 cover and the basement has recorded a maximum temperature of $\sim 330^{\circ} \mathrm{C}$, constant across 895 the whole massif and that the shortening was accommodated by top-to-the west shear zones 896 that progressively localized from 34 to $25 \mathrm{Ma}$, before the ECM were finally exhumed above 897 a crustal ramp after 15-20 Ma, which in turn controlled shortening in the deformed cover 898 further west (Vercors Massif).

899

900 Acknowledgments

901

902 This research was funded by the European Research Council (ERC) under the seventh 903 Framework Programme of the European Union (ERC Advanced Grant, grant agreement 904 No 290864, RHEOLITH) and has received funding from the BRGM (contract L10 U 044).

905 We would like to thank M. Sellos and M. Vacelet for constructing discussions and for their 906 help in the field; J.-G. Badin, S. Janiec for thin-section preparation. Y. Rolland and T. 907 Dumont are thanked for constructive comments that greatly improved the quality of a 908 previous manuscript.

909

910

\section{References}

911

912

913

914

915

Agard, P., L. Jolivet, and B. Goffe (2001), Tectonometamorphic evolution of the Schistes Lustres Complex; implications for the exhumation of HP and UHP rocks in the Western Alps, Bulletin de la Societe Geologique de France, 172(5), 617-636, doi:10.2113/172.5.617.

Agard, P., P. Monié, L. Jolivet, and B. Goffé (2002), Exhumation of the Schistes Lustrés complex: in situ laser probe 40Ar/39Ar constraints and implications for the Western Alps, Journal of Metamorphic Geology, 20(6), 599-618, doi:10.1046/j.1525-

919 1314.2002.00391.x. 
937

938

939

940

941

942

943

944

945

946

947

948

949

950

951

952

953

954

955

956

957

958

Allen, P. A., and J. R. Allen (2005), Basin analysis: principles and applications, 2nd ed., John Wiley \& Sons Inc.

Angiboust, S. (2011). Couplages profonds et comportement de la lithosphère océanique dans les zones de subduction: approches pétrologiques et thermomécaniques (Doctoral dissertation, Paris 6).

Aoya, M., Y. Kouketsu, S. Endo, H. Shimizu, T. Mizukami, D. Nakamura, and S. Wallis (2010), Extending the applicability of the Raman carbonaceous-material geothermometer using data from contact metamorphic rocks, Journal of Metamorphic Geology, 28(9), 895-914, doi:10.1111/j.1525-1314.2010.00896.x.

Aprahamian, J. (1974), La cristallinité de l'illite et les minéraux argileux en bordure des massifs cristallins externes de Belledonne et du Pelvoux (Variations et relations possibles avec des événements tectoniques et métamorphiques alpins), Géologie Alpine, 50, 5-15.

Aprahamian, J. (1988), Mapping of low to very low-grade metamorphism in the External Zone of the French Alps by use of illite crystallinity index. Geodinamica Acta (Paris), 2(1), 25-32.

Augier, R., P. Agard, P. Monié, L. Jolivet, C. Robin, and G. Booth-Rea (2005), Exhumation, doming and slab retreat in the Betic Cordillera (SE Spain): in situ40Ar/39Ar ages and $\mathrm{P}-\mathrm{T}-\mathrm{d}-\mathrm{t}$ paths for the Nevado-Filabride complex, Journal of Metamorphic Geology, 23(5), 357-381, doi:10.1111/j.1525-1314.2005.00581.x.

Baggio, P., G. Ferrara, and R. Malaroda (1967), Results of some Rb/Sr age determinations of the rocks of the Mont Blanc tunnel, Boll. Soc. Geol. Ital, 86, 193-212.

Barbier, R. (1963), La tectonique de la zone ultradauphinoise au NE du Pelvoux, Géologie Alpine, 39, 239-246.

Barbier, R., J.-C. Barféty,P. Bocquet, P. Le Fort, J. Meloux, R. Mouterde, A. Pêcher, and M. Petitteville (1973),Geological map and explanatory text of the sheet $\mathrm{n}^{\circ} 798$ "la Grave", scale: 1:50000, ed. BRGM.

Barféty,J.-C., P. Bordet, F. Carme, J. Debelmas, M. Meloux, G. Montjuvent, R. Mouterde, and J. Sarrot-Reynauld (1972), Geological map and explanatory text of the sheet n`797 "Vizille", scale: 1:50000, ed. BRGM.

Barféty, J. C., and A. Pêcher (1984), Geological map and explanatory text of the sheet n ${ }^{\circ} 822$ "St Christophe en Oisans," Carte géologique de la France au 1/50 000, BRGM, Orléans, France.

Barféty, J. C., J. Blaise, J.-C. Fourneaux, and J. Méloux (1984), Geological map and explanatory text of the sheet n ${ }^{\circ} 750$ "La Rochette," Carte géologique de la France au 1/50 000, BRGM, Orléans, France.

Barféty, J. C., G. Montjuvent, A. Pêcher, and F. Carme (1988), Geological map and explanatory text of the sheet n 821 "La Mure," Carte géologique de la France au 1/50 000, BRGM, Orléans, France. 
Barféty, J.-C., and M. Gidon (1983), La stratigraphie et la structure de la couverture dauphinoise au Sud de Bourg d'Oisans. Leurs relations avec les déformations synsédimentaires jurassiques, Géologie Alpine, 59, 5-32.

Barlier, J., J.-P. Ragot, and J.-C. Touray (1974), L'évolution des Terres noires subalpine méridionales d'après l'analyse minéralogique des argiles et la réflectométrie des particules carbonées., Bulletin du BRGM, 2(6), 533-548.

Bartoli, F., A. Pêcher, and P. Vialon (1974), Le chevauchement Meije-Muzelle et la répartition des domaines structuraux alpins du massif de l'Oisans (partie Nord du Haut-Dauphiné cristallin), Géologie Alpine, 50, 17-26.

Beach, A. (1981a), Some observations on the development of thrust faults in the Ultradauphinois Zone, French Alps, Geological Society, London, Special Publications, 9, 329-334, doi:10.1144/GSL.SP.1981.009.01.29.

Beach, A. (1981b), Thrust tectonics and cover-basement relations on the northern margin of the Pelvoux massif, French Alps, Eclogae Geologicae Helvetiae, 74(2), 471-479.

Beach, A. (1982), Strain analysis in a cover thrust zone, external French Alps, Tectonophysics, 88(3-4), 333-346, doi:10.1016/0040-1951(82)90245-1.

Beardsmore, G. R., \& Cull, J. P. (2001). Crustal heat flow: a guide to measurement and modelling. Cambridge University Press.

Van der Beek, P. A., P. G. Valla, F. Herman, J. Braun, C. Persano, K. J. Dobson, and E. Labrin (2010), Inversion of thermochronological age-elevation profiles to extract independent estimates of denudation and relief history - II: Application to the French Western Alps, Earth and Planetary Science Letters, 296, 9-22.

Bellahsen, N., L. Jolivet, O. Lacombe, M. Bellanger, A. Boutoux, S. Garcia, F. Mouthereau, L. Le Pourhiet, and C. Gumiaux (2012), Mechanisms of margin inversion in the external Western Alps: Implications for crustal rheology, Tectonophysics, 560 561(0), 62-83, doi:10.1016/j.tecto.2012.06.022.

Bellahsen, N., F. Mouthereau, A. Boutoux, M. Bellanger, O. Lacombe, L. Jolivet, and Y. Rolland (2014), Collision kinematics in the western external Alps, Tectonics, 33, 1055-1088, doi:10.1002/2013TC003453.

Bellanger, M. (2013). Raccourcissement alpin du massif des Ecrins: cinématique, calendrier tectonique et conditions pression-température (Doctoral dissertation, Orléans).

Bellanger, M., N. Bellahsen, L. Jolivet, T. Baudin, R. Augier, and A. Boutoux (2014), Basement shear zones development and shortening kinematics in the Ecrins Massif, Western Alps, Tectonics, 33, 84-111, doi:10.1002/2013TC003294.

Berger, A., and R. Bousquet (2008), Subduction-related metamorphism in the Alps: review of isotopic ages based on petrology and their geodynamic consequences, Geological Society, London, Special Publications, 298(1), 117-144, doi:10.1144/SP298.7. 
997

998

999

1000

1001

1002

1003

1004

1005

1006

1007

1008

1009

1010

1011

1012

1013

1014

1015

1016

1017

1018

1019

1020

1021

1022

1023

1024

1025

1026

1027

1028

1029

1030

1031

1032

1033

1034

1035

Bernard, D. (1978), Microthermometrie des inclusions fluides de cristaux syn-cinematiques. Application à la couverture sedimentaire du Nord Pelvoux., Univ. Grenoble, France.

Beucher, R. (2009), Évolution Néogène de l'Arc Alpin sud-occidental. Approches sismotectonique et thermochronologique, Univ. Joseph Fourier, Grenoble, France.

Beucher, R., P. van der Beek, J. Braun, and G. E. Batt (2012), Exhumation and relief development in the Pelvoux and Dora-Maira massifs (western Alps) assessed by spectral analysis and inversion of thermochronological age transects, J. Geophys. Res., 117(F3), n/a-n/a, doi:10.1029/2011JF002240.

Beyssac, O., B. Goffé, C. Chopin, and J. N. Rouzaud (2002), Raman spectra of carbonaceous material in metasediments: a new geothermometer, Journal of Metamorphic Geology, 20(9), 859-871, doi:10.1046/j.1525-1314.2002.00408.x.

Beyssac, O., Bollinger, L., Avouac, J. P., \& Goffé, B. (2004). Thermal metamorphism in the lesser Himalaya of Nepal determined from Raman spectroscopy of carbonaceous material. Earth and Planetary Science Letters, 225(1), 233-241.

Beyssac, O., Simoes, M., Avouac, J. P., Farley, K. A., Chen, Y. G., Chan, Y. C., \& Goffé, B. (2007). Late Cenozoic metamorphic evolution and exhumation of Taiwan. Tectonics, 26(6).

Bigot-Cormier, F., G. Poupeau, and M. Sosson (2000), Dénudations différentielles du massif cristallin externe alpin de l'Argentera (Sud-Est de la France) révélées par thermochronologie traces de fission (apatites, zircons), Comptes Rendus de l'Académie des Sciences - Series IIA - Earth and Planetary Science, 330(5), 363370, doi:10.1016/S1251-8050(00)00127-0.

Bogdanoff, S., A. Michard, M. Mansour, and G. Poupeau (2000), Apatite fission track analysis in the Argentera massif: evidence of contrasting denudation rates in the External Crystalline Massifs of the Western Alps, Terra Nova, 12(3), 117-125, doi:10.1046/j.1365-3121.2000.123281.x.

Bouillin, J.P., Pecher, A., Rolland, Y., Carrio, E., Dumont, T. and Tricart, P., (1997). Les filons sédimentaires jurassiques du Pelvoux, enregistreurs des déformations alpines de la bordure orientale du massif cristallin externe de l'Oisans (Alpes occidentales). C. R. Acad. Sci.Paris, 324, 409-415.

Boullier, A.-M. (1999), Fluid inclusions: tectonic indicators, Journal of Structural Geology, 21(8-9), 1229-1235, doi:10.1016/S0191-8141(99)00039-5.

Boutoux, A., Bellahsen, N., Lacombe, O., Verlaguet, A., \& Mouthereau, F. (2014a). Inversion of pre-orogenic extensional basins in the external Western Alps: Structure, microstructures and restoration. Journal of Structural Geology, 60, 13-29.

Boutoux, A., Verlaguet, A., Bellahsen, N., Lacombe, O., Villemant, B., Caron, B., ... \& Cartigny, P. (2014b). Fluid systems above basement shear zones during inversion of pre-orogenic sedimentary basins (External Crystalline Massifs, Western Alps). Lithos, accepted. DOI: 10.1016/j.lithos.2014.07.005 
1036

1037

1038

1039

1040

1041

1042

1043

1044

1045

1046

1047

1048

1049

1050

1051

1052

1053

1054

1055

1056

1057

1058

1059

1060

1061

1062

1063

1064

1065

1066

1067

1068

1069

1070

1071

1072

1073

1074

Bravard, C., and M. Gidon (1979), La structure du revers oriental du Massif du Pelvoux: Observations et interprétations nouvelles, Géologie Alpine, 55, 23-33.Burgisser, J., and M. Ford (1998), Overthrust shear deformation of a foreland basin; structural studies southeast of the Pelvoux massif, SE France, Journal of Structural Geology, 20(11), 1455-1475.

Brereton, N. R. (1970). Corrections for interfering isotopes in the ${ }^{40} \mathrm{Ar} /{ }^{39} \mathrm{Ar}$ dating method. Earth and Planetary Science Letters, 8(6), 427-433.

Butler, R. W. H. (1989), The influence of pre-existing basin structure on thrust system evolution in the Western Alps, Geological Society, London, Special Publications, 44(1), 105-122, doi:10.1144/GSL.SP.1989.044.01.07.

Caby, R. (1973), Les plis transversaux dans les Alpes occidentales: implications pour la genèse de la chaîne alpine, Bulletin de la Société géologique de France, (5-6), 624634.

Cathelineau, M. (1988), Cation Site Occupancy in Chlorites and Illites as a Function of Temperature, Clay Minerals, 23(4), 471-485, doi:10.1180/claymin.1988.023.4.13.

Cathelineau, M., and D. Nieva (1985), A chlorite solid solution geothermometer the Los Azufres (Mexico) geothermal system, Contr. Mineral. and Petrol., 91(3), 235-244, doi:10.1007/BF00413350.

Cenki-Tok, B., J. R. Darling, Y. Rolland, B. Dhuime, and C. D. Storey (2013), Direct dating of mid-crustal shear zones with synkinematic allanite: new in situ U-Th-Pb geochronological approaches applied to the Mont Blanc massif, Terra Nova, n/a-n/a, doi:10.1111/ter.12066.

Ceriani, S., and S. M. Schmid (2004), From n-s collision to WNW-directed post-collisional thrusting and folding: Structural study of the Frontal Penninic Units in Savoie (Western Alps, France), Eclogae Geologicae Helvetiae, 97(3), 347-369.

Ceriani, S., B. Fugenschuh, and S. M. Schmid (2001), Multi-stage thrusting at the "Penninic Front" in the Western Alps between Mont Blanc and Pelvoux massifs, International Journal of Earth Sciences, 90(3), 685-702.

Ceriani, S., B. Fugenschuh, S. Potel, and S. Schmid (2003), Tectono-metamorphic evolution of the Frontal Penninic units of the Western Alps: correlation between low-grade metamorphism and tectonic phases, Swiss Bulletin of Mineralogy and Petrology, 83(2), 111-131.

Challandes, N., D. Marquer, and M. Villa (2008), P-T-t modelling, fluid circulation, and 39Ar-40Ar and Rb-Sr mica ages in the Aar Massif shear zones (Swiss Alps), Swiss Journal of Geosciences, 101(2), 269-288, doi:10.1007/s00015-008-1260-6.

Chemenda, A. I., M. Mattauer, J. Malavieille, and A. N. Bokun (1995), A mechanism for syn-collisional rock exhumation and associated normal faulting: Results from physical modelling, Earth and Planetary Science Letters, 132(1-4), 225-232, doi:10.1016/0012-821X(95)00042-B. 
Chopin, C. (1984), Coesite and pure pyrope in high-grade blueschists of the Western Alps: a first record and some consequences, Contr. Mineral. and Petrol., 86(2), 107-118, doi:10.1007/BF00381838.

Chopin, C., and H. Maluski (1980), 40Ar-39Ar dating of high pressure metamorphic micas from the Gran Paradiso area (Western Alps): Evidence against the blocking temperature concept, Contr. Mineral. and Petrol., 74(2), 109-122, doi:10.1007/BF01131997.

Clauzon, G. (1990), Genèse et évolution du piémont néogène subalpin du Bas-Dauphiné. Livret guide de l'excursion préforum du 3ème forum national de géomorphologie, Aix en Provence, Unité de recherche associé (URA) n 903 - C.N.R.S.

Cliff, R. A., A. C. Barnicoat, and S. Inger (1998), Early Tertiary eclogite facies metamorphism in the Monviso Ophiolite, Journal of Metamorphic Geology, 16(3), 447-455, doi:10.1111/j.1525-1314.1998.00147.x.

Corna, M., J.-L. Dommergues, C. Meister \& K. Page (1997) - Les faunes d'ammonites du Jurassique inférieur (Hettangien, Sinémurien et Pliensbachien) au nord du massif des Écrins (Oisans, Alpes occidentales). Revue de Paléobiologie, 16 : 321-409.

Corsini, M., G. Ruffet, and R. Caby (2004), Alpine and late-hercynian geochronological constraints in the Argentera Massif (Western Alps), Eclogae geol. Helv., 97(1), $3-$ 15, doi:10.1007/s00015-004-1107-8.

Crespo-Blanc, A., H. Masson, Z. Sharp, M. Cosca, and J. Hunziker (1995), A stable and 40Ar/39Ar isotope study of a major thrust in the Helvetic nappes (Swiss Alps): Evidence for fluid flow and constraints on nappe kinematics, Geological Society of America Bulletin, 107(10), 1129-1144, doi:10.1130/00167606(1995)107<1129:ASAAAI > 2.3.CO;2.

Crouzet, C., G. Menard, and P. Rochette (1999), High-precision three-dimensional paleothermometry derived from paleomagnetic data in an Alpine metamorphic unit, Geology, 27(6), 503-506.

Crouzet, C., P. Rochette, and G. Menard (2001), Experimental evaluation of thermal recording of successive polarities during uplift of metasediments, Geophysical Journal International, 145(3), 771-785.

Debon, F., and M. Lemmet (1999), Evolution of $\mathrm{Mg} / \mathrm{Fe}$ Ratios in Late Variscan Plutonic Rocks from the External Crystalline Massifs of the Alps (France, Italy, Switzerland), Journal of Petrology, 40(7), $1151-1185$.

Depardon, J. P. (1979), Les déformations de la couverture mésozoïque au Nord de l'Oisans, Université Claude Bernard - Lyon I.

Deville, E., and W. Sassi (2006), Contrasting thermal evolution of thrust systems: An analytical and modeling approach in the front of the western Alps, AAPG bulletin, 90(6), 887-907.

Dodson, M. H. (1973). Closure temperature in cooling geochronological and petrological systems. Contributions to Mineralogy and Petrology, 40(3), 259-274. 
1115

1116

1117

1118

1119

1120

1121

1122

1123

1124

1125

1126

1127

1128

1129

1130

1131

1132

1133

1134

1135

1136

1137

1138

1139

1140

1141

1142

1143

1144

1145

1146

1147

1148

1149

1150

Duchêne, S., J. Blichert-Toft, B. Luais, P. Telouk, J.-M. Lardeaux, and F. Albarede (1997), The Lu-Hf dating of garnets and the ages of the Alpine high-pressure metamorphism, Nature, 387(6633), 586-589, doi:10.1038/42446.

Dumont, T. (1988). Late Triassic-early Jurassic evolution of the western Alps and of their European foreland; initiation of the Tethyan rifting. Bulletin de la Société géologique de France, 4(4), 601-611.

Dumont T., 1998, Sea-level changes and early rifting of a European Tethyan margin in the Western Alps and SE France. In : Mesozoic and Cenozoic sequence stratigraphy of European basins, de Graciansky P.C., Hardenbol J., Jacquin T. \& Vail P., Eds., Soc. Econ. Petr. Geol Spec. Publ. 60, p. 623-639

Dumont, T., J. D. Champagnac, C. Crouzet, and P. Rochat (2008), Multistage shortening in the Dauphine zone (French Alps): the record of Alpine collision and implications for pre-Alpine restoration, Swiss Journal of Geosciences,101(1), S89-S110.

Dumont, T., T. Simon-Labric, C. Authemayou, and T. Heymes (2011), Lateral termination

of the north-directed Alpine orogeny and onset of westward escape in the Western

Alpine arc: Structural and sedimentary evidence from the external zone, Tectonics, 30(5), TC5006.

Dumont, T., S. Schwartz, S. Guillot, T. Simon-Labric, P. Tricart, and S. Jourdan (2012), Structural and sedimentary records of the Oligocene revolution in the Western Alpine arc, Journal of Geodynamics, 56, 18-38.

Dunlap, W. J. (1997), Neocrystallization or cooling? 40Ar/39Ar ages of white micas from low-grade mylonites, Chemical Geology, 143(3-4), 181-203, doi:10.1016/S00092541(97)00113-7.

Ellenberger, F. (1958), Etude géologique du pays de Vanoise (Savoie), Mémoire servant à la carte géologique de la France, BRGM.

Faure, G. (1986), Principles of Isotope Geology, John Wiley \& Sons.

Féraud, G., G. Ruffet, J. Stéphan, H. Lapierre, E. Delgado, and M. Popoff (1995), Nouvelles données géochronologiques sur le volcanisme paléogène des Alpes occidentales: existence d'un événement magmatique bref généralisé, in Séance Spéciale de la

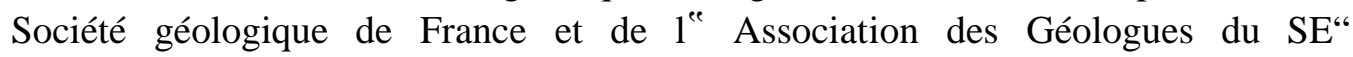
Magmatismes dans le sud-est de la France", Nice, pp. 25-26.

Ford, M. (1996), Kinematics and geometry of early Alpine, basement-involved folds, SW Pelvoux massif, SE France, Eclogae Geologicae Helvetiae, 89(1), 269-295.

Ford, M., and W. H. Lickorish (2004), Foreland basin evolution around the western Alpine Arc, edited by P. J. Lomas and S. A. Lomas, pp. 39-63, Geological Soc Publishing House, Bath. (online) Available from: <Go to ISI >://000223880200004 
1151

1152

1153

1154

1155

1156

1157

1158

1159

1160

1161

1162

1163

1164

1165

1166

1167

1168

1169

1170

1171

1172

1173

1174

1175

1176

1177

1178

1179

1180

1181

1182

1183

1184

1185

1186

1187

1188

1189

Du Fornel, E., P. Joseph, G. Desaubliaux, R. Eschard, F. Guillocheau, O. Lerat, C. Muller, C. Ravenne, and K. Sztràkos (2004), The southern Grès d'Annot outcrops (French Alps): an attempt at regional correlation, Geological Society, London, Special Publications, 221(1), 137-160, doi:10.1144/GSL.SP.2004.221.01.08.

Le Fort, P. (1973) - Geologie du Haut-Dauphiné cristallin (Alpes Française). Etude pétrologique et structurale de la partie occidentale. - Sci. de la terre, Nancy. Mem. $25,373 \mathrm{p}$.

Freeman, S. R., S. Inger, R. W. H. Butler, and R. A. Cliff (1997), Dating deformation using $\mathrm{Rb}-\mathrm{Sr}$ in white mica: Greenschist facies deformation ages from the Entrelor shear zone, Italian Alps, Tectonics, 16(1), 57-76, doi:10.1029/96TC02477.

Freeman, S. R., R. W. H. Butler, R. A. Cliff, S. Inger, and A. C. Barnicoat (1998), Deformation migration in an orogen-scale shear zone array: an example from the Basal Briançonnais Thrust, internal Franco-Italian Alps, Geological Magazine, 135(3), 349-367.

Fry, N. (1989), Southwestward thrusting and tectonics of the western Alps, Geological Society, London, Special Publications, 45(1), 83-109.

Fügenschuh, B., and S. M. Schmid (2003), Late stages of deformation and exhumation of an orogen constrained by fission-track data: A case study in the Western Alps, Geological Society of America Bulletin, 115(11), 1425-1440, doi:10.1130/B25092.1.

Gabalda, S., O. Beyssac, L. Jolivet, P. Agard, and C. Chopin (2009), Thermal structure of a fossil subduction wedge in the Western Alps, Terra Nova, 21(1), 28-34, doi:10.1111/j.1365-3121.2008.00849.x.

Ganne, J. (2003), Les dômes de socle HP-BT dans le domaine Pennique des Alpes NordOccidentales: modalité de leur exhumation., Univ. de Savoie, France.

Gasquet, D., J.-M. Bertrand, J.-L. Paquette, J. Lehmann, G. Ratzov, R. D. A. Guedes, M. Tiepolo, A.-M. Boullier, S. Scaillet, and S. Nomade (2010), Miocene to Messinian deformation and hydrothermal activity in a pre-Alpine basement massif of the French western Alps: new U-Th-Pb and argon ages from the Lauziere massif, Bulletin de la Société Géologique de France, 181(3), 227-241.

Gebauer, D., H.-P. Schertl, M. Brix, and W. Schreyer (1997), 35 Ma old ultrahigh-pressure metamorphism and evidence for very rapid exhumation in the Dora Maira Massif, Western Alps, Lithos, 41(1-3), 5-24, doi:10.1016/S0024-4937(97)82002-6.

Gerber, W. (2008), Evolution tectono-métamorphique du Briançonnais interne (Alpes Occidentales, massifs de Vanoise Sud et d'Ambin): comportement du socle et de sa couverture dans un contexte de subduction continentale profonde, Univ. Pierre et Marie Curie, France.

Gidon, M., and J.-L. Pairis (1980), Nouvelles données sur la structure des écailles de Soleil Boeuf (bordure sud du massif du Pelvoux), Bull. Bur. Rech. Geol. Min, 1, 35-41. 
1190

1191

1192

1193

1194

1195

1196

1197

1198

1199

1200

1201

1202

1203

1204

1205

1206

1207

1208

1209

1210

1211

1212

1213

Gratier, J. P., and P. Vialon (1980), Deformation pattern in a heterogeneous material folded and cleaved sedimentary cover immediately overlying a crystalline basement (Oisans, French Alps), Tectonophysics, 65(1), 151-180.

Gratier, J.-P., B. Lejeune, and V. Jean-Louis (1973), Etude des déformations de la couverture et des bordures sédimentaires des massifs cristallins externes de Belledonne, des Grandes Rousses et du Pelvoux (depuis des Aravis jusqu'à le région de Remollon), Université de Grenoble.

Gueydan, F., Leroy, Y. M., Jolivet, L., \& Agard, P. (2003). Analysis of continental midcrustal strain localization induced by microfracturing and

reaction-softening. Journal of Geophysical Research: Solid Earth (1978-2012),

108(B2).

Guillot, S., and R. Menot (1999), Nappe stacking and first evidence of Late Variscan extension in the Belledonne Massif (External Crystalline Massifs, French Alps), Geodinamica Acta, 12(2), 97-111.

Guillot, S., S. di Paola, R.-P. Ménot, P. Ledru, M. I. Spalla, G. Gosso, and S. Schwartz (2009), Suture zones and importance of strike-slip faulting for Variscan geodynamic reconstructions of the External Crystalline Massifs of the western Alps, Bulletin de la Societe Geologique de France, 180(6), 483-500, doi:10.2113/gssgfbull.180.6.483.

Gupta, S., and P. A. Allen (2000), Implications of foreland paleotopography for stratigraphic development in the Eocene distal Alpine foreland basin, Geological Society of America Bulletin, 112(4), 515-530.

Hames, W. E., \& Bowring, S. A. (1994). An empirical evaluation of the argon diffusion geometry in muscovite. Earth and Planetary Science Letters, 124(1), 161-169.

Hames, W. E., \& Cheney, J. T. (1997). On the loss of 40Ar* from muscovite during polymetamorphism. Geochimica et Cosmochimica Acta, 61(18), 3863-3872.

Harrison, T. M., J. Célérier, A. B. Aikman, J. Hermann, and M. T. Heizler (2009), Diffusion of $40 \mathrm{Ar}$ in muscovite, Geochimica et Cosmochimica Acta, 73(4), 1039-1051, doi:10.1016/j.gca.2008.09.038.

Henry, C., Burkhard, M., \& Goffe, B. (1996). Evolution of synmetamorphic veins and their wallrocks through a Western Alps transect: no evidence for large-scale fluid flow. Stable isotope, major-and trace-element systematics. Chemical Geology, 127(1), 81109.

Hurford, A. J., and J. C. Hunziker (1989), A revised thermal history for the Gran Paradiso massif, Schwei. Mineral. Petro. Mitt., 69(3), 319-329. 
Hurford, A. J., J. C. Hunziker, and B. Stöckhert (1991), Constraints on the late thermotectonic evolution of the western Alps: EVidence for episodic rapid uplift, Tectonics, 10(4), 758-769, doi:10.1029/91TC00167.

Ivaldi, J. P., Bellon, H., Guardia, P., Mangan, C., Müller, C., Perez, J. L., \& Terramorsi, S. (2003). Contexte lithostructural, âges ${ }^{40} \mathrm{~K} /{ }^{40} \mathrm{Ar}$ et géochimie du volcanisme calcoalcalin tertiaire de Cap-d'Ail dans le tunnel ferroviaire de Monaco. Comptes Rendus Geoscience,335(4), 411-421.

Jourdan, F., and P. R. Renne (2007), Age calibration of the Fish Canyon sanidine 40Ar/39Ar dating standard using primary K-Ar standards, Geochimica et Cosmochimica Acta, 71(2), 387-402, doi:10.1016/j.gca.2006.09.002.

Jullien, M., and B. Goffé (1993), Cookeite and pyrophyllite in the Dauphinois black shales (Isères, rance): implications for the conditions of metamorphism in the Alpine external zones, Schwei. Mineral. Petro. Mitt, 73, 357-363.

Kerckhove, C. (1969), La «zone du Flysch» dans les nappes de l'Embrunais-Ubaye (Alpes occidentales), Géologie Alpine, 45, 5-204.

Kirschner, D. L., M. A. Cosca, H. Masson, and J. C. Hunziker (1996), Staircase 40/Ar39Ar spectra of fine-grained white mica: Timing and duration of deformation and empirical constraints on argon diffusion, Geology, 24(8), 747-750, doi:10.1130/0091-7613(1996)024<0747:SAASOF>2.3.CO;2.

Kirschner, D. L., Masson, H., \& Sharp, Z. D. (1999). Fluid migration through thrust faults in the Helvetic nappes (Western Swiss Alps). Contributions to Mineralogy and Petrology, 136(1-2), 169-183.

Koppers, A. A. P. (2002), ArArCALC—software for 40Ar/39Ar age calculations, Computers \& Geosciences, 28(5), 605-619, doi:10.1016/S0098-3004(01)00095-4.

Kramar, N., M. A. Cosca, and J. C. Hunziker (2001), Heterogeneous 40Ar* distributions in naturally deformed muscovite: in situ UV-laser ablation evidence for microstructurally controlled intragrain diffusion, Earth and Planetary Science Letters, 192(3), 377-388, doi:10.1016/S0012-821X(01)00456-3.

Krummenacher, D., and J. F. Evernden (1960), Déterminations d'âge isotropique faites sur quelques roches des Alpes par la méthode Potassium-Argon, Schwei. Mineral. Petro. Mitt., 40, 267-277.

Lahfid, A., O. Beyssac, E. Deville, F. Negro, C. Chopin, and B. Goffé (2010), Evolution of the Raman spectrum of carbonaceous material in low-grade metasediments of the Glarus Alps (Switzerland), Terra Nova, 22(5), 354-360, doi:10.1111/j.13653121.2010.00956.x.

Lanari, P., S. Guillot, S. Schwartz, O. Vidal, P. Tricart, N. Riel, and O. Beyssac (2012), Diachronous evolution of the alpine continental subduction wedge: Evidence from $\mathrm{P}-\mathrm{T}$ estimates in the Briançonnais Zone houillère (France - Western Alps), Journal of Geodynamics, 56-57(0), 39-54, doi:10.1016/j.jog.2011.09.006. 
Laurent, J.-C. (1992), Les épisodes magmatiques filoniens basiques du Massif des PelvouxPelvoux entre Carbonifère et Lias, Université Joseph Fourier - Grenoble 1.

Leloup, P., N. Arnaud, E. Sobel, and R. Lacassin (2005), Alpine thermal and structural evolution of the highest external crystalline massif: The Mont Blanc Tectonics, 24(4), TC4002.

Lemoine, M. (1972), Rythme et Modalités des Plissements Superposés dans les Chaînes Subalpines Méridionales des Alpes Occidentales Française, Geologische Rundschau, 61(3), 975-1010.

Lemoine, M., and P. De Graciansky (1988), Histoire d'une marge continentale passive: les Alpes occidentales au Mésozoïque: introduction, Introduction: Bulletin de la Société Géologique de France, (8), t. IV(4), 597-600.

Lemoine, M., Bas, T., Arnaud-Vanneau, A., Arnaud, H., Dumont, T., Gidon, M., ... \& Tricart, P. (1986), The continental margin of the Mesozoic Tethys in the Western Alps, Marine and Petroleum Geology, 3(3), 179-199.

Leutwein, F., B. Poty, J. Sonet, and J. L. Zimmerman (1970), Age des cavités à cristaux du granite du Mont Blanc, CR Acad. Sci. Paris.

Malusà, M. G., R. Polino, M. Zattin, G. Bigazzi, S. Martin, and F. Piana (2005), Miocene to Present differential exhumation in the Western Alps: Insights from fission track thermochronology, Tectonics, 24(3), n/a-n/a, doi:10.1029/2004TC001782.

Maluski, H., and P. Monié (1988), 40Ar-39Ar laser probe multi-dating inside single biotites of a Variscan orthogeneiss (Pinet, Massif Central, France), Chemical Geology: Isotope Geoscience section, 73(3), 245-263, doi:10.1016/0168-9622(88)90005-X.

Marignac, C., M. Cathelineau, D. Bank, M.-C. Boiron, M. Ayt Ougoudal, Y. Argouarc'h, and B. Poty (1997), Alpine fault sealing at the contact between a crystalline basement and its sedimentary cover : La Gardette (French Alps). European current research on fluid 1027 inclusions. Biennial symposium No14, Nancy, FRANCE (01/07/1997), 194-195.

Marshall, D., N. Meisser, and R. P. Taylor (1998), Fluid inclusion, stable isotope and Ar-Ar evidence for the age and origin of gold-bearing quartz veins at Mont Chemin, Switzerland, Mineralogy and Petrology, 62(3-4), 147-165, doi:10.1007/BF01178027.

McDougall, I., and T. M. Harrison (1988), Geochronology and Thermochronology by the 40Ar/39Ar Method, Oxford University Press.

Meffan-Main, S., R. A. Cliff, A. C. Barnicoat, B. Lombardo, and R. Compagnoni (2004), A Tertiary age for Alpine high-pressure metamorphism in the Gran Paradiso massif, Western Alps: a Rb-Sr microsampling study, Journal of Metamorphic Geology, 22(4), 267-281, doi:10.1111/j.1525-1314.2004.00512.x.

Ménard, G. (1979), Relations entres structures profondes et structures superficielles dans le Sud-Est de la France. Essai d'utilisation de données Géophysiques, Université de Grenoble. 
Ménard, G., and P. Rochette (1992), Utilisation de reaimantations postmetamorphiques pour une etude de l'evolution tectonique et thermique tardive dans les Alpes occidentales (France), Bulletin de la Societe Geologique de France, 163(4), 381-392.

Michard, A., T. Dumont, L. Andreani, and N. Loget (2010), Cretaceous folding in the Dévoluy mountains (Subalpine Chains, France): gravity-driven detachment at the European paleomargin versus compressional event, Bulletin de la Societe Geologique de France, 181(6), 565-581.

Min, K., R. Mundil, P. R. Renne, and K. R. Ludwig (2000), A test for systematic errors in 40Ar/39Ar geochronology through comparison with $\mathrm{U} / \mathrm{Pb}$ analysis of a $1.1-\mathrm{Ga}$ rhyolite, Geochimica et Cosmochimica Acta, 64(1), 73-98, doi:10.1016/S00167037(99)00204-5.

Monié, P., and P. Philippot (1989), 39Ar-40Ar evidence for mid-Eocene high-pressure metamorphism in the Monviso ophiolitic massif, Comptes Rendus de l'Académie des Sciences - Series 2, 309(2), 245-251.

Mulch, A., and M. A. Cosca (2004), Recrystallization or cooling ages: in situ UV-laser 40Ar/39Ar geochronology of muscovite in mylonitic rocks, Journal of the Geological Society, 161(4), 573-582, doi:10.1144/0016-764903-110.

Mulch, A., M. Cosca, and M. Handy (2002), In-situ UV-laser 40Ar/39Ar geochronology of a micaceous mylonite : an example of defect-enhanced argon loss, Contrib Mineral Petrol, 142(6), 738-752, doi:10.1007/s00410-001-0325-6.

Mulch, A., M. A. Cosca, A. Andresen, and J. Fiebig (2005), Time scales of deformation and exhumation in extensional detachment systems determined by high-spatial resolution in situ UV-laser 40Ar/39Ar dating, Earth and Planetary Science Letters, 233(3-4), 375-390, doi:10.1016/j.eps1.2005.01.042.

Mulder, T., Callec, Y., Parize, O., Joseph, P., Schneider, J. L., Robin, C., ... \& Zaragosi, S. (2010). High-resolution analysis of submarine lobes deposits: Seismic-scale outcrops of the Lauzanier area (SE Alps, France). Sedimentary Geology, 229(3), 160-191., doi:10.1016/j.sedgeo.2009.11.005.

Müller, W. (2003), Strengthening the link between geochronology, textures and petrology, Earth and Planetary Science Letters, 206(3-4), 237-251, doi:10.1016/S0012821X(02)01007-5.

Mullis, J. (1996), P-T-t path of quartz formation in extensional veins of the Central Alps, Schwei. Mineral. Petro. Mitt., 76, 159-164.

Mullis, J., J. Dubessy, B. Poty, and J. O’Neil (1994), Fluid regimes during late stages of a continental collision: Physical, chemical, and stable isotope measurements of fluid inclusions in fissure quartz from a geotraverse through the Central Alps, Switzerland, Geochimica et Cosmochimica Acta, 58(10), 2239-2267, doi:10.1016/00167037(94)90008-6.

Negro, F., Beyssac, O., Goffé, B., Saddiqi, O., \& Bouybaouene, M. L. (2006). Thermal structure of the Alboran Domain in the Rif (northern Morocco) and the Western 
Betics (southern Spain). Constraints from Raman spectroscopy of carbonaceous material. Journal of Metamorphic Geology, 24(4), 309-327.

Nziengui, J.-J. (1993), Excès d'argon radiogénique dans les quartz des fissures tectoniques : implications pour la datation des séries métamorphiques. L'exemple de la coupe de la Romanche, Alpes Occidentales françaises, Univ. Joseph Fourier, Grenoble, France.

Pfiffner, A. (1992), Alpine orogeny, D. Blundell, R. Freeman and St. Mliller (Editors), A Continent Revealed: The European Geotraverse. Cambridge University Press, Cambridge, 180-190.

Philippe, Y., E. Deville, and A. Mascle (1998), Thin-skinned inversion tectonics at oblique basin margins: example of the western Vercors and Chartreuse Subalpine massifs (SE France), Geological Society, London, Special Publications, 134(1), 239-262, doi:10.1144/GSL.SP.1998.134.01.11.

Plunder, A., P. Agard, B. Dubacq, C. Chopin, and M. Bellanger (2012), How continuous and precise is the record of $\mathrm{P}-\mathrm{T}$ paths? Insights from combined thermobarometry and thermodynamic modelling into subduction dynamics (Schistes Lustrés, W. Alps), Journal of Metamorphic Geology, 30(3), 323-346, doi:10.1111/j.15251314.2011.00969.x.

Von Raumer, J., J. Abrecht, F. Bussy, B. Lombardo, R. Ménot, and U. Schaltegger (1999), The Palaeozoic metamorphic evolution of the Alpine external massifs, Schweiz. mineral. petrogr. Mitt, 79(1), 5-22.

Reddy, S. M., Kelley, S. P., \& Wheeler, J. (1996). A 40Ar/39Ar laser probe study of micas from the Sesia Zone, Italian Alps: implications for metamorphic and deformation histories. Journal of Metamorphic Geology, 14(4), 493-508.

Renne, P. R., C. C. Swisher, A. L. Deino, D. B. Karner, T. L. Owens, and D. J. DePaolo (1998), Intercalibration of standards, absolute ages and uncertainties in $40 \mathrm{Ar} / 39 \mathrm{Ar}$ dating, Chemical Geology, 145(1-2), 117-152, doi:10.1016/S0009-2541(97)001599.

Riche, P., and P. Trémolières (1987), Tectonique synsédimentaire sur la bordure orientale du bassin tertiaire de Valreas, Géologie Alpine, Mémoire H.S., 13, 409-416.

Rolland, Y., M. Rossi, S. F. Cox, M. Corsini, N. Mancktelow, G. Pennacchioni, M. Fornari, and A. M. Boullier (2008), 40Ar/39Ar dating of synkinematic white mica: insights from fluid-rock reaction in low-grade shear zones (Mont Blanc Massif) and constraints on timing of deformation in the NW external Alps, Geological Society, London, Special Publications, 299(1), 293-315, doi:10.1144/SP299.18.

Rolland, Y., S. F. Cox, and M. Corsini (2009), Constraining deformation stages in brittleductile shear zones from combined field mapping and Ar-40/Ar-39 dating: The structural evolution of the Grimsel Pass area (Aar Massif, Swiss Alps), Journal of Structural Geology, 31, 1377-1394. 
1382

1383

1384

1385

1386

1387

1388

1389

1390

1391

1392

1393

1394

1395

1396

1397

1398

1399

1400

1401

1402

1403

1404

1405

1406

1407

1408

1409

1410

1411

1412

1413

1414

1415

1416

1417

1418

1419

1420

1421

1422

Rosenbaum, G., and G. S. Lister (2005), The Western Alps from the Jurassic to Oligocene: spatio-temporal constraints and evolutionary reconstructions, Earth-Science Reviews, 69(3-4), 281-306, doi:10.1016/j.earscirev.2004.10.001.

Roux, M., J.-P. Bourseau, T. Bas, T. Dumont, P.-C. de Graciansky, M. Lemoine, and J.-L. Rudkiewicz (1988), Bathymetric evolution of the Tethyan margin in the western Alps (data from stalked crinoids): a reappraisal of eustatism problems during the Jurassic, Bulletin de la Société géologique de France, 4(4), 633-641.

Rubatto, D., and J. Hermann (2001), Exhumation as fast as subduction?, Geology, 29(1), 36, doi:10.1130/0091-7613(2001)029<0003:EAFAS>2.0.CO;2.

Rubatto, D., and J. Hermann (2003), Zircon formation during fluid circulation in eclogites (Monviso, Western Alps): implications for $\mathrm{Zr}$ and $\mathrm{Hf}$ budget in subduction zones, Geochimica et Cosmochimica Acta, 67(12), 2173-2187, doi:10.1016/S00167037(02)01321-2.

Ruffini, R., R. Polino, E. Callegari, J. Hunziker, and H. Pfeifer (1997), Volcanic clast-rich turbidites of the Tavayanne sandstones from the Thone syncline (Savoie, France): records for a tertiary postcollisional volcanism, Schweiz. Miner. Petrogr. Mitt, 77, $161-174$.

Sabil, N. (1995), La datation par traces de fission: aspects méthodologiques et applications thermochronologique en contexte Alpin et de Marge Continentale., Univ. Joseph Fourier, Grenoble, France.

Salles, L., M. Ford, P. Joseph, C. Le Carlier De Veslud, and A. Le Solleuz (2011), Migration of a synclinal depocentre from turbidite growth strata: the Annot syncline, SE France, Bulletin de la Societe Geologique de France, 182(3), 199-220.

Saliot, P. (1973). Les principales zones de métamorphisme dans les Alpes françaises. Répartition et signification. CR Acad. Sci. Paris, 276, 3081-3084.

Sanchez, G., Y. Rolland, J. Schneider, M. Corsini, E. Oliot, P. Goncalves, C. Verati, J.-M. Lardeaux, and D. Marquer (2011a), Dating low-temperature deformation by 40Ar/39Ar on white mica, insights from the Argentera-Mercantour Massif (SW Alps), Lithos, 125(1), 521-536.

Sanchez, G., Y. Rolland, M. Jolivet, S. Brichau, M. Corsini, and A. Carter (2011b), Exhumation controlled by transcurrent tectonics: the Argentera-Mercantour massif (SW Alps), Terra Nova, 23(2), 116-126.

Scaillet, S., G. Féraud, Y. Lagabrielle, M. Ballévre, and G. Ruffet (1990), 40Ar/39Ar laserprobe dating by step heating and spot fusion of phengites from the Dora Maira nappe of the western Alps, Italy, Geology, 18(8), 741-744, doi:10.1130/00917613(1990)018<0741:AALPDB>2.3.CO;2.

Scaillet, S., G. Feraud, M. Ballevre, and M. Amouric (1992), MgFe and ((Mg,Fe)Si-Al2) compositional control on argon behaviour in high-pressure white micas: A 40Ar39Ar continuous laser-probe study from the Dora-Maira nappe of the internal western Alps, Italy, Geochimica et Cosmochimica Acta, 56(7), 2851-2872, doi:10.1016/0016-7037(92)90364-O. 
Schaeffer, O., H. W. Mueller, and T. L. Grove (1977), Laser Ar-39-Ar-40 study of Apollo 17 basalts, vol. Proceedings. Volume 2. (A78-41551 18-91), New York, Pergamon, Houston.

Schwartz, S., J. M. Lardeaux, P. Tricart, S. Guillot, and E. Labrin (2007), Diachronous exhumation of HP-LT metamorphic rocks from south-western Alps: evidence from fission-track analysis, Terra Nova, 19(2), 133-140.

Seward, D., and N. S. Mancktelow (1994), Neogene kinematics of the central and western Alps: Evidence from fission-track dating, Geology, 22(9), 803-806, doi:10.1130/0091-7613(1994)022<0803:NKOTCA>2.3.CO;2.

Simon-Labric, T., Y. Rolland, T. Dumont, T. Heymes, C. Authemayou, M. Corsini, and M. Fornari (2009), Ar-40/Ar-39 dating of Penninic Front tectonic displacement (W Alps) during the Lower Oligocene (31-34 Ma), Terra Nova,21(2), 127-136.

Sinclair, H. D. (1997), Tectonostratigraphic model for underfilled peripheral foreland basins: An Alpine perspective, Geological Society of America Bulletin, 109(3), 324346, doi:10.1130/0016-7606(1997)109<0324:TMFUPF>2.3.CO;2.

Strzerzynski, P., S. Guillot, P. H. Leloup, N. Arnaud, O. Vidal, P. Ledru, G. Courrioux, and X. Darmendrail (2012), Tectono-metamorphic evolution of the Briançonnais zone (Modane-Aussois and Southern Vanoise units, Lyon Turin transect, Western Alps), Journal of Geodynamics, 56-57(0), 55-75, doi:10.1016/j.jog.2011.11.010.

Tilton, G. R., W. Schreyer, and H.-P. Schertl (1991), $\mathrm{Pb}-\mathrm{Sr}-\mathrm{Nd}$ isotopic behavior of deeply subducted crustal rocks from the Dora Maira Massif, Western Alps, Italy-II: what is the age of the ultrahigh-pressure metamorphism?, Contr. Mineral. and Petrol., 108(12), 22-33, doi:10.1007/BF00307323.

Tricart, P., S. Schwartz, C. Sue, G. Poupeau, and J.-M. Lardeaux (2001), La denudation tectonique de la zone ultradauphinoise et l'inversion du front brianconnais au sud-est du Pelvoux (Alpes occidentales); une dynamique miocene a actuelle, Bulletin de la Societe Geologique de France, 172(1), 49-58, doi:10.2113/172.1.49.

Tricart, P., S. Schwartz, C. Sue, and J.-M. Lardeaux (2004), Evidence of synextension tilting and doming during final exhumation from analysis of multistage faults (Queyras Schistes lustrés, Western Alps), Journal of Structural Geology, 26(9), 1633-1645, doi:10.1016/j.jsg.2004.02.002.

Tricart, P., J.-M. Lardeaux, S. Schwartz, and C. Sue (2006), The late extension in the inner western Alps: a synthesis along the south-Pelvoux transect, Bulletin de la Societe Geologique de France, 177(6), 299-310, doi:10.2113/gssgfbull.177.6.299.

Tricart, P., P. Van der Beek, S. Schwartz, and E. Labrin (2007), Diachronous late-stage exhumation across the western Alpine arc: constraints from apatite fission-track thermochronology between the Pelvoux and Dora-Maira Massifs, Journal of the Geological Society, 164(1), 163-174. 

Variscan high-grade units (South Armorican Domain, western France), combined structural and 40Ar/39Ar constraints. Tectonics, 30(5).

Vernon, A. J., Van Der Beek, P. A., Sinclair, H. D., \& Rahn, M. K. (2008). Increase in late Neogene denudation of the European Alps confirmed by analysis of a fission-track thermochronology database. Earth and Planetary Science Letters, 270(3), 316-329.

Vidal, O., T. Parra, and F. Trotet (2001), A Thermodynamic Model for Fe-Mg Aluminous

Waibel, A. F. (1990), Sedimentology, petrographic variability and very-low-garde metamorphism of the Champsaur sandstone (Paleogene, Hautes-Alpes, France). Evolution of Volcaniclastic Foreland Turbidites in the External Western Alps., Univ. Genève, Switzerland.

West, D. P., and D. R. Lux (1993), Dating mylonitic deformation by the 40Ar-39Ar method: An example from the Norumbega Fault Zone, Maine, Earth and Planetary Science Letters, 120(3-4), 221-237, doi:10.1016/0012-821X(93)90241-Z.

De Wever, P., and R. Caby (1981), Datation de la base des schistes lustrés postophiolithiques par des radiolaires (Oxfordien supérieur? Kimmeridgien moyen) dans les Alpes Cottiennes (Saint Véran, France), Comptes Rendus de l'Academie des Sciences, 292, 467-472.

De Wever, P., T. Danelian, M. Durand-Delga, F. Cordey, and N. Kito (1987), Datations des radiolarites post-ophiolitiques de Corse alpine à l'aide des Radiolaires, CR Acad. Sci. Paris, 305, 893-900. 
Wibberley, C. (1999), Are feldspar-to-mica reactions necessarily reaction-softening processes in fault zones?, Journal of Structural Geology, 21(8), 1219-1227.

Wibberley, C. A. . (2005), Initiation of basement thrust detachments by fault-zone reaction weakening, Geological Society, London, Special Publications, 245, 347-372.

Wijbrans, J. R., \& McDougall, I. (1986). 40Ar/39Ar dating of white micas from an Alpine high-pressure metamorphic belt on Naxos (Greece): the resetting of the argon isotopic system. Contributions to Mineralogy and Petrology, 93(2), 187-194.

York, D. (1968), Least squares fitting of a straight line with correlated errors, Earth and Planetary Science Letters, 5(0), 320-324, doi:10.1016/S0012-821X(68)80059-7. of terrestrial minerals with a continuous laser, Geophys. Res. Lett., 8(11), 11361138, doi:10.1029/GL008i011p01136.

Figure captions

Figure 1: (a) Large-scale tectonic map of the Western Alps. Indicated is the location of the figure 2 that embraces the whole studied area. (b) Geological cross-section across the studied area close to the 45th parallel modified from Bellanger et al. (2014).

1517 Figure 2: Simplified structural map of the studied area modified from Bellanger et al. 1518 (2014). Indicated is the location of the studied samples either form the Mesozoic cover for RSCM and chlorite geothermometry or from the basement shear zones for chlorite geothermometry and for the ${ }^{40} \mathrm{Ar} /{ }^{39} \mathrm{Ar}$ in situ approach. See tables for precise locations of samples.

Figure 3: Deformation features of the Oisans Massif at decreasing scales. (a) kilometer-scale view as illustrated by a geological cross-section from the Penninic Frontal Thrust (PFT) to La Mure Massif. Note the distribution of the Alpine shear zones and the overall eastward increasing of the finite strain intensity; (b) landscape-scale view as illustrated by a picture of a part of the Plan du Lac shear zone in the Vénéon Valley. Note the anastomosed relationships of the shear planes, the folded shape of the basement-cover interface and the pinched part of Mesozoic cover. Field-sketch diagrams represent macroscopic features of 
1530 the deformation from mylonite to phyllonite at outcrop-scale. (c) Thin-section pictures

1531 showing small-scale deformation features of from proto-mylonite to phyllonite strain-stage.

1532 Note the clear increase of the phengite fraction with strain increasing.

1534 Figure 4: First-order results from the Raman Spectrometry of Carbonaceous Material 1535 approach. (a) RSCM Map showing mapping of the $\mathrm{T}_{\max }$ results and inferred isotherms. The 1536 isotherm shape was drawn from interpolated map and from the distribution of the Illite 1537 crystallinity; (b) Illite crystallinity map modified from Aprahamian (1974) and Barlier et al. 1538 (1974). (c) Projection of the RSCM Tmax over a classical E-W cross-section from the west 1539 of the Belledonne Massif to the Penninic Frontal Thrust. (d and e) RSCM Tmax results vs. 1540 longitude and elevation along the cross-section (c). Data represented with smaller symbols 1541 to the east of the Penninic Frontal Thrust come from Beyssac et al. (2002); Gabalda et al. 1542 (2009); Lanari et al. (2012) and Plunder et al. (2012). Detailed results are given in table 1.

Figure 5: Local-scale features of results from the Raman Spectrometry of Carbonaceous Material approach. (a) Distribution of the Tmax to the west of the Belledonne Massif from RSCM (circle) and vitrinite reflectance results (star; data from Deville and Sassi (2006) transformed into temperatures using the equation proposed in Allen and Allen (2005). The distribution of the Tmax in the sedimentary pile is aligned along a ca. $30-50{ }^{\circ} \mathrm{C} \cdot \mathrm{km}^{-1}$ gradient. Besides, temperature gaps across narrow zones highlight localized tectonic contacts. (b) Distribution of the RSCM Tmax results close to the Lautaret and Galibier passes. The structural data come from Depardon (1979), Beach (1981a, 1982), Ceriani et al. (2001), and Bellanger (2013). Note that the distribution of the Tmax within the tectonic pile is consistent with a ca. $20-30{ }^{\circ} \mathrm{C} \cdot \mathrm{km}^{-1}$ post-tectonic field gradient. Detailed results are given 1554 in table 1.

1556 Figure 6: Chlorite composition and results from chlorite geothermometry the Mesozoic cover. (a) XMg vs. Silica content diagram. (b) Clinochlore/Amesite/Sudoite ternary plot. 1558 Note that chlorite composition is first controlled by the bulk composition of the protolith. (c) 1559 Internal consistency of the geothermometric results. Chlorite geothermometry results using 
1560 both thermodynamic and empirical approaches (Cathelineau and Nieva, 1985, Vidal et al., $15612005,2006)$ are compared to RSCM data. Chlorite probably records a part of the cooling 1562 (retrograde) evolution. Detailed results are given in table 2.

1563

1564 Figure 7: Example of microstructural and composition of sample A.4.64 used as a guideline 1565 for dated samples. (a) Contrasted habits of white-micas as seen on several close-up views 1566 from the same thin-section. (b) White-mica chemical composition in ternary plots and $\mathrm{XMg}$ 1567 vs. Silica content diagram. Fine-grained, often syn-kinematic white-micas present in C-type 1568 and S-type foliation have phengite compositions. Well-developed white-mica clasts have a 1569 muscovite composition.

1570 Figure 8: White-micas composition and chlorite geothermometry from dated samples 1571 (basement shear zones). For each of the dated shear zone, presented is the composition of 1572 white-micas as a function to their textural position in $\mathrm{Si}$ vs. Na content diagram and 1573 Muscovite/Celadonite/Pyrophyllite ternary plot together with results of chlorite 1574 geothermometry using both thermodynamic and empirical approaches (Cathelineau and 1575 Nieva, 1985, Vidal et al., 2001, 2005, 2006). Detailed results are given in table 2. (a) 1576 corresponds to results for the Col de Cluy shear zone while (b), (c) and (d) correspond to 1577 Plan du Lac, Col du Lac and Combeynot shear zones, respectively. Due to a very poor dataset, results for the Combeynot shear zone are not shown.

1579

1580 Figure 9: Time-chart showing all results of the in situ ${ }^{40} \mathrm{Ar} /{ }^{39} \mathrm{Ar}$ approach. Detailed results are given in table 3. Stratigraphic age for the Nummulitic flysch deposit is from Mulder et al. (2010); zircon and apatite fission-tracks results from Van der Beek et al. (2010).

1584 Figure 10: Pictures showing the distribution of in situ laser ablation of the ${ }^{40} \mathrm{Ar} /{ }^{39} \mathrm{Ar}$ 1585 approach. Note the overall dependency of the K/Ar system to the finite strain intensity. 1586 Detailed results are given in table 3. 
1588 Figure 11: Pressure-Temperature-deformation-time evolution of the Oisans Massif. (a)

1589 Pressure-Temperature (P-T) constraints for the Oisans Massif. The P-T data come from

1590 (Gratier et al., 1973; Bernard, 1978) and references therein (Thermobarometry from fluids

1591 inclusions and paragenesis from cover and basement veins), (Jullien and Goffé, 1993)

1592 (conventional metamorphic petrology from the Emparis basin Mesozoic cover, (Crouzet et

1593 al., 1999) (thermopaleomagnetism from the Bourg d'Oisans basin), (Ceriani et al., 2003)

1594 (Zircon fission track and Kübler index and b-cell dimension of white mica fom the

1595 Nummulitic cover of the Cheval noir unit), this study (RSCM from Mesozoic and

1596 Nummulitic cover). Temperature-deformation-time (T-d-t) constraints for the Oisans

1597 Massif. The T-d-t data come from (1) (Nziengui, 1993); (2) (Jullien and Goffé, 1993); (3)

1598 this study; (4) (Crouzet et al., 1999); (5) (Ménard and Rochette, 1992); (6) (Crouzet et al.,

1599 2001); (7) (van der Beek et al., 2010); (8) (Sabil, 1995; van der Beek et al., 2010; Beucher et 1600 al., 2012).

1601

1602 Figure 12: Large-scale compilation of existing time-constraints for the External zone and for 1603 the Western Alps close to the 45th parallel. (1) (Riche and Trémolières, 1987) (2) (Clauzon, 1604 1990) (3) (Philippe et al., 1998) (4) (Du Fornel et al., 2004) (5) (Mulder et al., 2010) (6) 1605 (Féraud et al., 1995) (7) (Marignac et al., 1997) (8) (Gasquet et al., 2010) (9) (Simon-Labric 1606 et al., 2009) (a: Combeynot sinistral strike-slip shear zone; b: Pelvoux dextral strike-slip 1607 shear zone; c: Ailefroide dextral strike-slip shear zone); (10) this study; (11) (Nziengui, 1608 1993) (12) (Crouzet et al., 1999, 2001) (13) (van der Beek et al., 2010) (14) (Sabil, 1995; 1609 van der Beek et al., 2010; Beucher et al., 2012) (15-16) (Fügenschuh and Schmid, 2003) 1610 (17) (Ceriani and Schmid, 2004) (18) (Ceriani et al., 2003; Fügenschuh and Schmid, 2003) 1611 (19) (Fügenschuh and Schmid, 2003) (20) (Féraud et al., 1995) (21) (Corsini et al., 2004) 1612 (22) (Sanchez et al., 2011a) (23) (Bigot-Cormier et al., 2000) (24) (Bigot-Cormier et al., 1613 2000; Bogdanoff et al., 2000; Sanchez et al., 2011b) (25) (Pfiffner, 1992) (26) (Ruffini et al., 1614 1997) (27-29) (Leutwein et al., 1970) (30) (Marshall et al., 1998) (31) (Crespo-Blanc et al., 1615 1995) (32) (Kirschner et al., 1996) (33-34) (Rolland et al., 2008) (35) (Krummenacher and 1616 Evernden, 1960) (36) (Leutwein et al., 1970) (37-40) (Leloup et al., 2005) (41) (Baggio et 1617 al., 1967) (42-43) (Seward and Mancktelow, 1994; Leloup et al., 2005) (44-45) (Fügenschuh 1618 and Schmid, 2003) (46) (Freeman et al., 1998) (47) (Beucher, 2009) (48-49) (Fügenschuh 1619 and Schmid, 2003; Tricart et al., 2007) (50) (Ellenberger, 1958) (51) (Ganne, 2003) (52) 1620 (Gerber, 2008) (53) (Malusà et al., 2005) (54-56) (Ganne, 2003) (57-61) (Gerber, 2008) (62) 
1621 (Strzerzynski et al., 2012) (63) (Freeman et al., 1997) (64) (Agard et al., 2002) (65)

1622 (Duchêne et al., 1997) (66) (Rubatto and Hermann, 2003) (67) (Monié and Philippot, 1989)

1623 (68-69) (Cliff et al., 1998) (70-71) (Schwartz et al., 2007; Tricart et al., 2007; Beucher, 1624 2009) (72) (Agard et al., 2002) (73) (Duchêne et al., 1997) (74) (Gebauer et al., 1997) (75)

1625 (Rubatto and Hermann, 2001) (76 et 78) (Tilton et al., 1991) (77) (Scaillet et al., 1992) (79)

1626 (Gebauer et al., 1997) (80) (Beucher et al., 2012) (81 et 83) (Chopin and Maluski, 1980)

1627 (82) (Ganne, 2003) (84) (Meffan-Main et al., 2004) (85-86) (Hurford and Hunziker, 1989;

1628 Hurford et al., 1991).

1629 Figure 13: Lithospheric reconstructions of the Alps along a cross-section close to the 45th 1630 parallel. See text for explanations.

1631

1632 Table captions

1633

1634 Table 1: Detailed results from the RSCM approach. Given are the GPS position (latitude 1635 (Lat.) and longitude (Long.) in decimal degrees (WGS84) and the elevation in meter), the 1636 tectonic unit, the stratigraphic age, the lithology, the number of Raman spectra (Sp.), the R2 1637 or the RA1 ratio, the RSCM temperature (mean and standard deviation). R2 ratio, in regular 1638 font (Beyssac et al., 2002) or the RA1 ratio, in italic font (Lahfid et al. 2010) was preferred depending on the shape of the spectra and the presence of the D4 peak (Lahfid et al., 2010).

1640

1641 Table 2: Detailed results from the chlorite geothermometry approach. Given are the GPS 1642 position (latitude (Lat.) and longitude (Long.) in decimal degrees (WGS84) and results of 1643 thermodynamic and empirical approaches (Cathelineau and Nieva, 1985, Vidal et al., 2005, 1644 2006). Results are presented separately for the Mesozoic cover and the basement (Alpine 1645 shear zones).

1646

1647 Table 3: Detailed results from the ${ }^{40} \mathrm{Ar} /{ }^{39} \mathrm{Ar}$ approach. Given are the GPS position (latitude

1648 (Lat.) and longitude (Long.) in decimal degrees (WGS84) in decimal degrees (WGS84) and 1649 different output isotopic ratio.

1650 


\begin{tabular}{|c|c|c|c|c|c|c|c|c|c|c|}
\hline & 182 & 26.68 & \pm 0.86 & 5.52 & 0.09 & 16.617 & 31.735 & 5.459 & 20 & \\
\hline & 184 & 27.25 & \pm 0.70 & 5.64 & 0.07 & 13.268 & 74.860 & 3.342 & 13 & \\
\hline & 185 & 37.15 & \pm 0.98 & 7.71 & 0.10 & 16.231 & 17.350 & 5.288 & 15 & \\
\hline & 186 & 32.60 & \pm 0.78 & 6.75 & 0.08 & 15.331 & 28.381 & 3.749 & 12 & \\
\hline & 188 & 23.22 & \pm 0.57 & 4.80 & 0.06 & 14.716 & 0.397 & 2.635 & 12 & \\
\hline & 189 & 26.87 & \pm 0.71 & 5.56 & 0.07 & 14.822 & 3.060 & 3.589 & 14 & \\
\hline & 190 & 33.63 & \pm 3.54 & 6.97 & 0.37 & 20.026 & 14.646 & 30.393 & 53 & \\
\hline & 192 & 34.59 & \pm 3.37 & 7.17 & 0.35 & 20.946 & 10.029 & 28.806 & 51 & \\
\hline & 193 & 32.12 & \pm 1.04 & 6.65 & 0.11 & 17.515 & 17.526 & 7.044 & 21 & \\
\hline & 194 & 26.78 & \pm 3.41 & 5.54 & 0.36 & 24.354 & 10.163 & 29.142 & 57 & \\
\hline & 196 & 28.71 & \pm 3.55 & 5.94 & 0.37 & 19.039 & 0.466 & 30.419 & 56 & \\
\hline & 197 & 30.02 & \pm 2.49 & 6.22 & 0.26 & 19.316 & 27.056 & 20.857 & 46 & \\
\hline & 198 & 28.68 & \pm 1.10 & 5.93 & 0.11 & 15.174 & 13.405 & 7.848 & 25 & \\
\hline & 200 & 35.20 & \pm 2.99 & 7.30 & 0.31 & 19.635 & 14.784 & 25.369 & 47 & \\
\hline & 201 & 25.89 & \pm 0.76 & 5.35 & 0.08 & 14.485 & 16.121 & 3.516 & 14 & 44 \\
\hline A-4-68b (Ech5) & 79 & 101.14 & \pm 2.19 & 21.36 & 0.24 & 19.325 & 21.345 & 8.756 & 10 & \\
\hline Plan du Lac & 80 & 26.78 & \pm 0.62 & 5.54 & 0.06 & 14.705 & 7.379 & 2.725 & 11 & \\
\hline Gneiss & 82 & 25.90 & \pm 0.52 & 5.35 & 0.05 & 13.112 & 5.208 & 0.772 & 3 & \\
\hline Lat.: $44.984950^{\circ}$ & 83 & 101.52 & \pm 4.58 & 21.44 & 0.50 & 36.434 & 26.990 & 37.570 & 33 & \\
\hline \multirow{17}{*}{ Lon.: $6.143560^{\circ}$} & 85 & 87.86 & \pm 3.53 & 18.48 & 0.38 & 30.597 & 18.766 & 27.850 & 30 & \\
\hline & 86 & 114.24 & \pm 4.28 & 24.21 & 0.47 & 32.663 & 43.649 & 33.490 & 28 & \\
\hline & 88 & 57.58 & \pm 1.80 & 12.01 & 0.19 & 19.509 & 20.365 & 12.438 & 22 & \\
\hline & 89 & 59.11 & \pm 1.88 & 12.34 & 0.20 & 22.043 & 10.178 & 13.115 & 23 & \\
\hline & 91 & 65.70 & \pm 2.07 & 13.74 & 0.22 & 23.431 & 8.778 & 14.399 & 22 & \\
\hline & 92 & 96.56 & \pm 2.86 & 20.36 & 0.31 & 25.972 & 15.399 & 19.551 & 21 & \\
\hline & 94 & 52.37 & \pm 1.65 & 10.91 & 0.17 & 22.259 & 6.778 & 11.386 & 22 & \\
\hline & 95 & 102.17 & \pm 2.88 & 21.58 & 0.31 & 27.804 & 9.330 & 18.937 & 20 & \\
\hline & 96 & 37.80 & \pm 1.17 & 7.84 & 0.12 & 18.793 & 2.915 & 7.892 & 21 & \\
\hline & 98 & 38.11 & \pm 0.99 & 7.91 & 0.10 & 12.649 & 108.017 & 5.226 & 15 & \\
\hline & 99 & 27.07 & \pm 0.61 & 5.60 & 0.06 & 15.396 & 1.553 & 2.420 & 10 & \\
\hline & 101 & 37.89 & \pm 0.99 & 7.86 & 0.10 & 17.127 & 0.000 & 5.366 & 15 & \\
\hline & 102 & 42.32 & \pm 1.06 & 8.79 & 0.11 & 18.704 & 16.415 & 5.553 & 14 & \\
\hline & 104 & 71.99 & \pm 1.71 & 15.08 & 0.18 & 20.856 & 38.529 & 6.467 & 11 & \\
\hline & 105 & 49.19 & \pm 1.09 & 10.24 & 0.11 & 15.637 & 22.946 & 3.927 & 9 & \\
\hline & 107 & 57.58 & \pm 1.30 & 12.01 & 0.14 & 17.453 & 18.965 & 5.279 & 11 & \\
\hline & 108 & 61.32 & \pm 1.35 & 12.80 & 0.14 & 17.214 & 6.628 & 5.273 & 10 & 21 \\
\hline
\end{tabular}

Table 3 


\begin{tabular}{|c|c|c|c|c|c|c|c|c|c|c|}
\hline & 317 & 159.84 & \pm 9.51 & 34.09 & 1.06 & 42.598 & 100.620 & 81.736 & 41 & \multirow[b]{4}{*}{40} \\
\hline & 318 & 83.59 & \pm 2.05 & 17.45 & 0.22 & 19.188 & 33.359 & 10.534 & 14 & \\
\hline & 319 & 116.28 & \pm 2.50 & 24.50 & 0.27 & 19.849 & 18.212 & 8.634 & 9 & \\
\hline & 320 & 89.33 & \pm 2.20 & 18.68 & 0.24 & 19.482 & 126.785 & 6.793 & 9 & \\
\hline$\overline{A-4-66 b}$ & 19 & 37.78 & \pm 3.17 & 7.79 & 0.33 & 21.743 & 41.626 & 26.734 & $\overline{47}$ & \\
\hline Plan du Lac & 20 & 37.63 & \pm 2.03 & 7.76 & 0.21 & 19.494 & 7.915 & 16.086 & 35 & \\
\hline Gneiss & 26 & 38.95 & \pm 1.54 & 8.03 & 0.16 & 15.253 & 0.760 & 11.468 & 27 & \\
\hline Lat.: $44.982410^{\circ}$ & 27 & 36.87 & \pm 2.03 & 7.60 & 0.21 & 17.892 & 2.116 & 16.419 & 36 & \\
\hline \multirow[t]{30}{*}{ Lon.: $6.147040^{\circ}$} & 29 & 301.42 & \pm 6.56 & 66.91 & 0.79 & 35.325 & 0.000 & 34.137 & 13 & \\
\hline & 30 & 62.29 & \pm 1.41 & 12.93 & 0.15 & 16.109 & 16.173 & 6.088 & 11 & \\
\hline & 33 & 129.05 & \pm 3.03 & 27.29 & 0.33 & 27.668 & 8.263 & 15.628 & 14 & \\
\hline & 34 & 36.00 & \pm 0.98 & 7.42 & 0.10 & 12.959 & 0.000 & 5.512 & 16 & \\
\hline & 37 & 35.72 & \pm 1.89 & 7.36 & 0.20 & 22.241 & 35.724 & 14.517 & 34 & \\
\hline & 39 & 32.67 & \pm 1.63 & 6.73 & 0.17 & 17.296 & 12.892 & 12.831 & 33 & \\
\hline & 40 & 32.08 & \pm 1.10 & 6.60 & 0.11 & 14.308 & 7.733 & 7.737 & 23 & \\
\hline & 42 & 30.72 & \pm 1.09 & 6.32 & 0.11 & 14.967 & 0.000 & 7.800 & 24 & \\
\hline & 43 & 32.87 & \pm 1.14 & 6.77 & 0.12 & 13.521 & 3.686 & 8.014 & 23 & \\
\hline & 45 & 33.49 & \pm 0.77 & 6.90 & 0.08 & 13.770 & 2.480 & 3.254 & 11 & \\
\hline & 46 & 33.55 & \pm 0.82 & 6.91 & 0.09 & 13.321 & 3.816 & 4.022 & 13 & \\
\hline & 48 & 29.17 & \pm 0.68 & 6.00 & 0.07 & 14.767 & 13.296 & 2.745 & 10 & \\
\hline & 49 & 29.58 & \pm 0.67 & 6.08 & 0.07 & 15.319 & 13.327 & 2.398 & 9 & \\
\hline & 51 & 31.49 & \pm 0.65 & 6.48 & 0.07 & 13.435 & 4.182 & 1.473 & 5 & \\
\hline & 52 & 31.98 & \pm 0.70 & 6.58 & 0.07 & 14.403 & 2.899 & 2.587 & 9 & \\
\hline & 54 & 33.12 & \pm 0.79 & 6.82 & 0.08 & 14.390 & 5.062 & 3.737 & 12 & \\
\hline & 55 & 39.81 & \pm 0.89 & 8.21 & 0.09 & 14.321 & 2.465 & 3.589 & 10 & \\
\hline & 57 & 37.33 & \pm 2.48 & 7.70 & 0.26 & 18.621 & 8.016 & 20.685 & 41 & \\
\hline & 58 & 31.65 & \pm 2.39 & 6.51 & 0.25 & 19.490 & 4.940 & 20.049 & 44 & \\
\hline & 60 & 35.03 & \pm 1.33 & 7.22 & 0.14 & 18.049 & 2.470 & 9.941 & 26 & \\
\hline & 61 & 34.70 & \pm 1.35 & 7.15 & 0.14 & 18.266 & 3.038 & 10.078 & 27 & \\
\hline & 63 & 37.84 & \pm 0.96 & 7.80 & 0.10 & 15.423 & 5.192 & 5.144 & 15 & \\
\hline & 64 & 40.50 & \pm 1.06 & 8.35 & 0.11 & 18.151 & 4.933 & 6.022 & 16 & \\
\hline & 66 & 36.59 & \pm 1.26 & 7.54 & 0.13 & 18.187 & 8.598 & 8.838 & 23 & \\
\hline & 67 & 38.66 & \pm 1.45 & 7.97 & 0.15 & 18.954 & 7.837 & 10.731 & 26 & \\
\hline & 69 & 47.58 & \pm 1.20 & 9.83 & 0.13 & 16.492 & 6.142 & 6.583 & 15 & \\
\hline & 70 & 125.56 & \pm 3.47 & 26.52 & 0.38 & 36.088 & 10.440 & 22.749 & 20 & \\
\hline & 72 & 31.89 & \pm 0.88 & 6.56 & 0.09 & 16.576 & 0.000 & 4.987 & 16 & \\
\hline & 73 & 30.51 & \pm 0.74 & 6.28 & 0.08 & 14.076 & 2.988 & 3.610 & 13 & \\
\hline & 74 & 30.90 & \pm 0.72 & 6.36 & 0.07 & 14.087 & 5.008 & 3.139 & 11 & 34 \\
\hline$A-4-68$ & 245 & 61.32 & \pm 2.22 & 12.72 & 0.23 & 19.501 & 25.355 & 16.475 & $\overline{26}$ & \\
\hline Plan du Lac & 246 & 40.61 & \pm 2.03 & 8.38 & 0.21 & 21.339 & 32.150 & 16.278 & 34 & \\
\hline Gneiss & 247 & 31.80 & \pm 0.80 & 6.55 & 0.08 & 15.058 & 19.614 & 4.127 & 14 & \\
\hline Lat.: $44.984950^{\circ}$ & 249 & 28.77 & \pm 1.17 & 5.92 & 0.12 & 16.462 & 21.462 & 8.823 & 27 & \\
\hline Lon.: $6.143560^{\circ}$ & 250 & 93.51 & \pm 2.10 & 19.58 & 0.23 & 24.615 & 5.839 & 9.355 & 12 & \\
\hline & 251 & 74.73 & \pm 1.81 & 15.56 & 0.19 & 24.938 & 42.041 & 9.522 & 14 & \\
\hline & 253 & 24.28 & \pm 1.26 & 4.99 & 0.13 & 15.279 & 87.896 & 9.612 & 32 & \\
\hline & 254 & 25.98 & \pm 1.67 & 5.34 & 0.17 & 16.846 & 9.266 & 13.651 & 39 & \\
\hline & 255 & 49.36 & \pm 2.18 & 10.21 & 0.23 & 26.893 & 34.100 & 17.096 & 31 & \\
\hline & 257 & 32.08 & \pm 1.17 & 6.60 & 0.12 & 21.853 & 29.097 & 8.412 & 25 & \\
\hline & 258 & 24.47 & \pm 0.77 & 5.03 & 0.08 & 16.339 & 36.424 & 4.936 & 19 & \\
\hline & 259 & 32.06 & \pm 1.34 & 6.60 & 0.14 & 24.525 & 32.552 & 10.214 & 28 & \\
\hline & 264 & 25.79 & \pm 0.79 & 5.30 & 0.08 & 16.313 & 21.900 & 5.101 & 19 & \\
\hline & 265 & 22.35 & \pm 0.90 & 4.59 & 0.09 & 15.449 & 29.685 & 6.636 & 26 & \\
\hline & 266 & 36.85 & \pm 0.87 & 7.60 & 0.09 & 16.856 & 28.362 & 4.120 & 12 & 15 \\
\hline$A-4-68 b(E c h 8)$ & 144 & 24.88 & \pm 0.54 & 5.14 & 0.06 & 12.752 & 3.706 & 0.478 & $\overline{2}$ & \\
\hline Plan du Lac & 145 & 27.16 & \pm 1.41 & 5.62 & 0.15 & 17.908 & 0.000 & 0.000 & 0 & \\
\hline Gneiss & 146 & 26.65 & \pm 0.55 & 5.51 & 0.06 & 13.920 & 0.000 & 0.507 & 2 & \\
\hline Lat.: $44.984950^{\circ}$ & 148 & 25.74 & \pm 0.56 & 5.32 & 0.06 & 14.891 & 0.000 & 0.727 & 3 & \\
\hline Lon.: $6.143560^{\circ}$ & 149 & 25.16 & \pm 0.55 & 5.20 & 0.06 & 14.784 & 0.000 & 0.583 & 3 & \\
\hline & 150 & 25.95 & \pm 0.55 & 5.37 & 0.06 & 14.536 & 12.917 & 0.570 & 3 & \\
\hline & 152 & 26.58 & \pm 0.69 & 5.50 & 0.07 & 12.124 & 5.811 & 0.701 & 3 & \\
\hline & 153 & 25.66 & \pm 2.89 & 5.30 & 0.30 & 12.211 & 0.000 & 0.066 & 0 & \\
\hline & 154 & 25.75 & \pm 3.15 & 5.32 & 0.33 & 12.126 & 271.884 & 0.184 & 0 & \\
\hline & 156 & 32.57 & \pm 3.85 & 6.75 & 0.40 & 10.353 & 108.067 & 1.046 & 4 & \\
\hline & 157 & 47.23 & \pm 1.41 & 9.82 & 0.15 & 11.567 & 168.834 & 3.893 & 9 & \\
\hline & 158 & 46.40 & \pm 1.90 & 9.65 & 0.20 & 17.515 & 18.150 & 14.508 & 29 & \\
\hline & 160 & 201.82 & $\begin{array}{r} \pm 12.76 \\
\end{array}$ & 43.83 & 1.46 & 46.660 & 2794.213 & 115.611 & 42 & \\
\hline & 161 & 25.34 & \pm 0.63 & 5.24 & 0.07 & 14.586 & 8.934 & 0.558 & 3 & \\
\hline & 162 & 28.20 & \pm 0.64 & 5.83 & 0.07 & 15.229 & 181.960 & 2.092 & 8 & \\
\hline & 164 & 25.22 & \pm 0.59 & 5.21 & 0.06 & 14.405 & 2.375 & 2.040 & 9 & \\
\hline & 165 & 28.43 & \pm 1.02 & 5.88 & 0.11 & 14.576 & 75.735 & 7.377 & 24 & \\
\hline & 166 & 27.73 & \pm 1.10 & 5.74 & 0.12 & 14.654 & 0.432 & 8.144 & 26 & \\
\hline & 168 & 25.92 & \pm 0.58 & 5.36 & 0.06 & 10.834 & 14.811 & 0.693 & 3 & \\
\hline & 169 & 25.30 & \pm 0.53 & 5.23 & 0.05 & 12.533 & 13.464 & 0.821 & 4 & \\
\hline & 170 & 32.25 & \pm 0.74 & 6.68 & 0.08 & 14.533 & 15.877 & 2.877 & 10 & \\
\hline & 172 & 31.89 & \pm 0.86 & 6.61 & 0.09 & 14.772 & 25.511 & 4.845 & 16 & \\
\hline & 173 & 26.67 & \pm 0.61 & 5.52 & 0.06 & 13.389 & 0.000 & 2.188 & 9 & \\
\hline & 174 & 32.11 & \pm 0.84 & 6.65 & 0.09 & 14.983 & 227.616 & 4.170 & 13 & \\
\hline & 176 & 26.71 & \pm 0.62 & 5.52 & 0.07 & 10.443 & 40.681 & 2.076 & 9 & \\
\hline & 177 & 28.76 & \pm 0.68 & 5.95 & 0.07 & 14.683 & 11.784 & 2.458 & 9 & \\
\hline & 178 & 30.74 & \pm 0.66 & 6.36 & 0.07 & 12.792 & 56.401 & 1.576 & 6 & \\
\hline & 180 & 31.38 & \pm 2.22 & 6.50 & 0.23 & 15.375 & 6.264 & 18.517 & 42 & \\
\hline & 181 & 26.39 & \pm 0.57 & 5.46 & 0.06 & 13.365 & 44.315 & 1.762 & 7 & \\
\hline & 182 & 26.68 & \pm 0.86 & 5.52 & 0.09 & 16.617 & 31.735 & 5.459 & 20 & \\
\hline
\end{tabular}


ACCEPTED MANUSERIPT

\begin{tabular}{|c|c|c|c|c|c|c|c|c|c|c|}
\hline Sample & An. & Age & $(+2 s)$ & $40 * / 39(\mathrm{k})$ & $1 s$ & $38 A r / 39 A r$ & $37 \mathrm{Ar} / 39 \mathrm{Ar}$ & $36 A r / 39 A r$ & $\%$ Atm $n$ & $n$ \\
\hline & & & & & & $(* 1000)$ & $(* 1000)$ & $(* 1000)$ & & \\
\hline A-1-345 & 110 & 389.51 & \pm 27.17 & 89.23 & 3.46 & 109.716 & 5.672 & 280.279 & $\overline{48}$ & \\
\hline Combeynot & 111 & 315.64 & \pm 11.36 & 70.80 & 1.39 & 62.828 & 8.248 & 100.136 & 29 & \\
\hline Porphyroid & 113 & 199.95 & \pm 5.88 & 43.40 & 0.67 & 34.056 & 22.486 & 42.774 & 22 & \\
\hline Lat.: $45.026510^{\circ}$ & 114 & 330.96 & \pm 7.53 & 74.56 & 0.93 & 42.462 & 3.763 & 44.245 & 15 & \\
\hline \multirow[t]{11}{*}{ Lon.: $6.404380^{\circ}$} & 116 & 294.73 & \pm 6.91 & 65.72 & 0.83 & 40.937 & 5.032 & 43.083 & 16 & \\
\hline & 117 & 290.84 & \pm 6.72 & 64.78 & 0.81 & 36.516 & 0.000 & 40.250 & 15 & \\
\hline & 119 & 231.14 & \pm 6.59 & 50.62 & 0.77 & 38.998 & 4.310 & 48.412 & 22 & \\
\hline & 120 & 276.63 & \pm 9.00 & 61.37 & 1.08 & 50.417 & 8.596 & 74.129 & 26 & \\
\hline & 122 & 231.91 & \pm 5.81 & 50.80 & 0.68 & 38.043 & 4.734 & 37.637 & 18 & \\
\hline & 123 & 221.72 & \pm 6.55 & 48.43 & 0.76 & 40.747 & 2.831 & 49.034 & 23 & \\
\hline & 125 & 169.08 & \pm 3.29 & 36.39 & 0.37 & 13.650 & 11.799 & 3.969 & 3 & \\
\hline & 126 & 272.85 & \pm 5.81 & 60.46 & 0.69 & 29.630 & 24.865 & 17.269 & 8 & \\
\hline & 128 & 252.54 & \pm 4.98 & 55.64 & 0.59 & 16.655 & 37.405 & 7.473 & 4 & \\
\hline & 129 & 156.32 & \pm 3.22 & 33.52 & 0.36 & 21.734 & 4.032 & 7.403 & 6 & \\
\hline & 130 & 206.61 & \pm 4.42 & 44.93 & 0.51 & 33.808 & 22.324 & 11.769 & 7 & 15 \\
\hline A-1-355 & 205 & 30.82 & \pm 1.00 & 6.38 & 0.10 & 18.330 & 67.910 & 5.718 & $\overline{18}$ & \\
\hline Col du Lac & 206 & 38.08 & \pm 3.64 & 7.90 & 0.38 & 58.001 & 138.816 & 11.462 & 27 & \\
\hline Gneiss & 207 & 32.87 & \pm 0.88 & 6.81 & 0.09 & 15.744 & 85.272 & 2.104 & 7 & \\
\hline Lat.: $45.017860^{\circ}$ & 209 & 27.30 & \pm 0.80 & 5.65 & 0.08 & 16.684 & 40.285 & 4.607 & 17 & \\
\hline \multirow[t]{26}{*}{ Lon.: $6.273540^{\circ}$} & 210 & 27.06 & \pm 0.99 & 5.60 & 0.10 & 16.173 & 83.580 & 5.847 & 20 & \\
\hline & 211 & 24.80 & \pm 0.76 & 5.13 & 0.08 & 15.227 & 32.113 & 3.441 & 14 & \\
\hline & 213 & 24.80 & \pm 0.57 & 5.13 & 0.06 & 13.758 & 26.275 & 2.476 & 11 & \\
\hline & 214 & 26.58 & \pm 1.41 & 5.50 & 0.15 & 30.685 & 83.420 & 4.539 & 17 & \\
\hline & 215 & 26.02 & \pm 0.65 & 5.38 & 0.07 & 16.349 & 154.835 & 2.906 & 11 & \\
\hline & 217 & 32.34 & \pm 1.05 & 6.70 & 0.11 & 16.960 & 124.361 & 7.162 & 21 & \\
\hline & 218 & 27.13 & \pm 0.91 & 5.61 & 0.09 & 17.432 & 244.419 & 5.225 & 18 & \\
\hline & 219 & 27.77 & \pm 1.05 & 5.74 & 0.11 & 19.465 & 251.880 & 6.967 & 23 & \\
\hline & 221 & 26.22 & \pm 0.66 & 5.42 & 0.07 & 15.212 & 51.173 & 2.493 & 10 & \\
\hline & 222 & 88.86 & \pm 8.58 & 18.70 & 0.93 & 22.432 & 121.326 & 71.317 & 52 & \\
\hline & 223 & 58.72 & \pm 2.12 & 12.25 & 0.22 & 22.361 & 24.720 & 14.784 & 25 & \\
\hline & 225 & 27.22 & \pm 0.88 & 5.63 & 0.09 & 15.473 & 93.917 & 5.594 & 20 & \\
\hline & 226 & 31.72 & \pm 1.11 & 6.57 & 0.12 & 19.244 & 109.244 & 6.726 & 20 & \\
\hline & 227 & 26.44 & \pm 2.01 & 5.47 & 0.21 & 18.452 & 89.430 & 16.213 & 42 & \\
\hline & 229 & 41.30 & \pm 1.63 & 8.58 & 0.17 & 15.750 & 79.334 & 11.810 & 27 & \\
\hline & 230 & 30.61 & \pm 1.13 & 6.34 & 0.12 & 19.183 & 111.046 & 5.922 & 19 & \\
\hline & 231 & 23.88 & \pm 1.64 & 4.93 & 0.17 & 16.507 & 58.995 & 13.359 & 40 & \\
\hline & 233 & 27.55 & \pm 1.44 & 5.70 & 0.15 & 10.904 & 120.782 & 9.622 & 29 & \\
\hline & 234 & 26.44 & \pm 4.85 & 5.47 & 0.50 & 16.482 & 272.598 & 41.140 & 64 & \\
\hline & 235 & 21.09 & \pm 4.19 & 4.36 & 0.44 & 23.129 & 37.242 & 36.304 & 67 & \\
\hline & 237 & 14.54 & \pm 9.58 & 3.00 & 0.99 & 31.718 & 0.581 & 83.039 & 86 & \\
\hline & 238 & 33.41 & \pm 2.36 & 6.92 & 0.25 & 22.418 & 113.398 & 18.933 & 41 & \\
\hline & 239 & 42.68 & \pm 2.22 & 8.87 & 0.23 & 15.109 & 82.208 & 16.743 & 33 & \\
\hline & 241 & 36.11 & \pm 2.27 & 7.49 & 0.24 & 19.655 & 164.103 & 18.251 & 38 & \\
\hline & 242 & 109.75 & \pm 7.11 & 23.23 & 0.78 & 27.052 & 135.090 & 49.364 & 38 & \\
\hline & 243 & 37.65 & \pm 2.33 & 7.81 & 0.24 & 24.920 & 87.031 & 18.521 & 38 & 30 \\
\hline$\overline{A-4-74 b}$ & 268 & 169.77 & \pm 3.55 & 36.31 & 0.40 & 27.306 & 43.850 & 13.453 & $\overline{10}$ & \\
\hline Plan du Lac & 269 & 52.47 & \pm 1.07 & 10.86 & 0.11 & 16.745 & 55.616 & 2.240 & 5 & \\
\hline Gneiss & 270 & 74.94 & \pm 2.66 & 15.61 & 0.28 & 19.667 & 1412.051 & 14.647 & 19 & \\
\hline Lat.: $44.984930^{\circ}$ & 272 & 26.69 & \pm 0.60 & 5.48 & 0.06 & 12.978 & 52.107 & 1.561 & 7 & \\
\hline Lon.: $6.125820^{\circ}$ & 273 & 24.76 & \pm 0.68 & 5.09 & 0.07 & 13.439 & 3.485 & 3.354 & 14 & \\
\hline & 274 & 24.29 & \pm 1.75 & 4.99 & 0.18 & 16.268 & 13.714 & 14.242 & 41 & \\
\hline & 277 & 105.95 & \pm 2.91 & 22.26 & 0.32 & 31.313 & 74.487 & 7.328 & 9 & \\
\hline & 278 & 186.61 & \pm 4.40 & 40.10 & 0.50 & 26.968 & 0.000 & 22.227 & 14 & \\
\hline & 279 & 158.63 & \pm 4.59 & 33.82 & 0.51 & 28.448 & 79.390 & 30.843 & 21 & \\
\hline & 281 & 207.10 & \pm 5.24 & 44.76 & 0.60 & 34.788 & 41.001 & 32.855 & 18 & \\
\hline & 282 & 132.95 & \pm 4.52 & 28.14 & 0.50 & 31.099 & 26.803 & 32.926 & 25 & \\
\hline & 283 & 76.73 & \pm 3.65 & 15.99 & 0.39 & 12.256 & 154.469 & 25.925 & 31 & \\
\hline & 285 & 126.70 & \pm 3.73 & 26.77 & 0.41 & 22.875 & 33.883 & 24.493 & 21 & \\
\hline & 286 & 43.97 & \pm 5.66 & 9.08 & 0.59 & 22.167 & 48.539 & 48.845 & 59 & \\
\hline & 287 & 57.14 & \pm 1.27 & 11.84 & 0.13 & 16.889 & 58.258 & 4.372 & 9 & \\
\hline & 289 & 105.53 & \pm 2.37 & 22.17 & 0.26 & 21.393 & 37.534 & 6.227 & 7 & \\
\hline & 290 & 131.78 & \pm 3.12 & 27.89 & 0.34 & 26.144 & 18.864 & 14.691 & 13 & \\
\hline & 291 & 111.61 & \pm 6.66 & 23.49 & 0.72 & 37.316 & 48.608 & 54.146 & 40 & \\
\hline & 293 & 40.96 & \pm 0.98 & 8.45 & 0.10 & 18.950 & 68.986 & 1.636 & 5 & \\
\hline & 294 & 36.84 & \pm 0.82 & 7.59 & 0.09 & 16.349 & 5.038 & 2.719 & 9 & \\
\hline & 295 & 54.01 & \pm 1.35 & 11.18 & 0.14 & 20.151 & 2.290 & 6.796 & 14 & \\
\hline & 297 & 32.65 & \pm 0.93 & 6.72 & 0.10 & 16.406 & 321.626 & 4.222 & 13 & \\
\hline & 298 & 36.43 & \pm 0.87 & 7.51 & 0.09 & 14.979 & 25.149 & 1.999 & 6 & \\
\hline & 299 & 32.17 & \pm 0.80 & 6.62 & 0.08 & 15.178 & 20.601 & 3.209 & 11 & \\
\hline & 301 & 40.05 & \pm 0.91 & 8.26 & 0.09 & 13.792 & 14.734 & 2.443 & 7 & \\
\hline & 302 & 32.71 & \pm 0.81 & 6.73 & 0.08 & 13.812 & 102.166 & 1.986 & 7 & \\
\hline & 303 & 38.28 & \pm 1.00 & 7.89 & 0.10 & 15.011 & 2.251 & 5.515 & 16 & \\
\hline & 305 & 46.66 & \pm 1.09 & 9.64 & 0.11 & 17.635 & 42.403 & 4.734 & 12 & \\
\hline & 306 & 47.53 & \pm 1.15 & 9.83 & 0.12 & 17.989 & 25.982 & 5.711 & 13 & \\
\hline & 307 & 59.65 & \pm 1.67 & 12.37 & 0.18 & 19.478 & 125.491 & 9.956 & 18 & \\
\hline & 309 & 25.22 & \pm 1.08 & 5.18 & 0.11 & 15.696 & 103.169 & 8.232 & 28 & \\
\hline & 310 & 43.87 & \pm 1.14 & 9.06 & 0.12 & 16.736 & 4.395 & 6.180 & 15 & \\
\hline & 311 & 86.77 & \pm 3.01 & 18.13 & 0.32 & 26.519 & 11.467 & 22.305 & 26 & \\
\hline & 313 & 45.26 & \pm 1.45 & 9.35 & 0.15 & 20.073 & 12.845 & 9.898 & 22 & \\
\hline & 314 & 34.80 & \pm 1.04 & 7.17 & 0.11 & 16.355 & 471.527 & 6.146 & 17 & \\
\hline & 315 & 73.72 & \pm 3.24 & 15.35 & 0.34 & 28.247 & 13.271 & 25.751 & 32 & \\
\hline
\end{tabular}




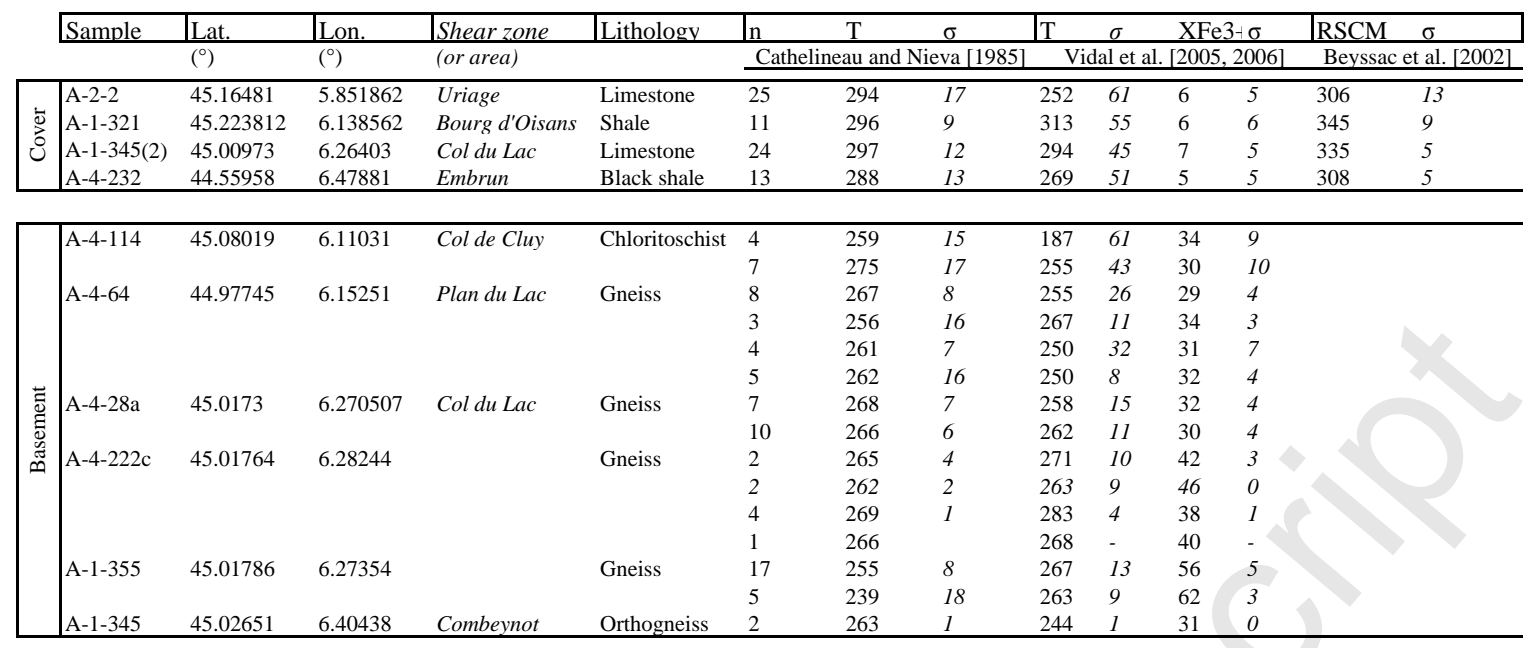

Table 2 


\begin{tabular}{|c|c|c|c|c|c|c|c|c|c|c|}
\hline Sample & Lat. & Lon. & Elev. & Tectonic unit & Stratigraphic age & Lithology & $n$ & $\mathrm{R} 2 / R A 1$ & \multicolumn{2}{|c|}{\begin{tabular}{|l|l|} 
Tmax & sd \\
\end{tabular}} \\
\hline & $\left({ }^{\circ}\right)$ & $\left({ }^{\circ}\right)$ & $(\mathrm{m})$ & & & & & ratio & $\left({ }^{\circ} \mathrm{C}\right)$ & $\left({ }^{\circ} \mathrm{C}\right)$ \\
\hline A-1-001 & 45.004578 & 5.70136 & 560 & Dauphinois & Upper Lias & Slate & 14 & 0.70 & 329 & 8 \\
\hline$A-1-004$ & 44.87225 & 5.86169 & 948 & Dauphinois & Upper Lias & Slate & 25 & 0.58 & 258 & 7 \\
\hline A-1-007 & 45.069906 & 6.000484 & 806 & Dauphinois & Lower Lias & Limestone & 12 & 0.72 & 321 & 6 \\
\hline A-1-009 & 45.08103 & 6.04491 & 1513 & Dauphinois & Lower Lias & Limestone & 13 & 0.71 & 327 & 3 \\
\hline A-1-016 & 45.03812 & 6.131952 & 1257 & Dauphinois & Lower Dogger & Slate & 12 & 0.63 & 321 & 12 \\
\hline A-1-025 & 45.14811 & 6.31462 & 1516 & Dauphinois & Upper Lias & Slate & 12 & 0.69 & 335 & 6 \\
\hline A-1-029 & 45.032105 & 6.381495 & 1952 & Dauphinois & Middle Dogger & Limestone & 12 & 0.69 & 335 & 2 \\
\hline A-1-030 & 45.038448 & 6.398698 & 2128 & Dauphinois & Lower Lias & Limestone & 11 & 0.69 & 333 & 4 \\
\hline A-1-32 & 45.042092 & 6.388473 & 2215 & Dauphinois & Priabonian & Flysch & 15 & 0.61 & 298 & 4 \\
\hline A-1-37 & 45.291423 & 6.324367 & 1485 & Dauphinois & Upper Lias & Slate & 12 & 0.69 & 333 & 2 \\
\hline A-1-171 & 45.226435 & 6.190374 & 2119 & Dauphinois & Lower Lias & Limestone & 12 & 0.71 & 327 & 5 \\
\hline A-1-208 & 45.062326 & 6.126121 & 1761 & Dauphinois & Lower Lias & Limestone & 11 & 0.63 & 319 & 8 \\
\hline A-1-224 & 45.049632 & 6.102744 & 1166 & Dauphinois & Lower Lias & Limestone & 11 & 0.70 & 330 & 5 \\
\hline A-1-225 & 45.037 & 5.97841 & 1120 & Dauphinois & Lower Lias & Limestone & 10 & 0.70 & 331 & 3 \\
\hline A-1-318 & 44.984199 & 6.123207 & 982 & Dauphinois & Upper Lias & Slate & 14 & 0.69 & 333 & 9 \\
\hline A-1-320 & 45.127996 & 6.045468 & 801 & Dauphinois & Upper Lias & Slate & 12 & 0.69 & 336 & 9 \\
\hline A-1-321 & 45.223812 & 6.138562 & 1770 & Dauphinois & Upper Lias & Slate & 11 & 0.67 & 345 & 9 \\
\hline A-1-322b & 45.21556 & 6.213118 & 1794 & Dauphinois & Upper Lias & Slate & 12 & 0.70 & 329 & 3 \\
\hline A-1-323 & 45.215115 & 6.252217 & 1461 & Dauphinois & Upper Lias & Slate & 12 & 0.69 & 336 & 8 \\
\hline A-1-324 & 45.192802 & 6.290928 & 1271 & Dauphinois & Lower Lias & Limestone & 12 & 0.69 & 332 & 3 \\
\hline$A-1-326$ & 45.200339 & 6.336937 & 1502 & Dauphinois & Lower Dogger & Slate & 11 & 0.63 & 322 & 10 \\
\hline A-1-327 & 45.218918 & 6.305905 & 1290 & Dauphinois & Upper Lias & Slate & 11 & 0.66 & 347 & 4 \\
\hline A-1-328 & 45.227265 & 6.303567 & 1240 & Dauphinois & Lower Lias & Limestone & 11 & 0.69 & 336 & 5 \\
\hline A-1-329 & 45.249661 & 6.28425 & 1286 & Dauphinois & Lower Dogger & Slate & 8 & 0.69 & 334 & 5 \\
\hline A-1-330 & 45.2608 & 6.367982 & 776 & Dauphinois & Lower Dogger & Slate & 12 & 0.66 & 347 & 6 \\
\hline A-1-331 & 45.291702 & 6.23121 & 1107 & Dauphinois & Upper Lias & Slate & 12 & 0.69 & 332 & 12 \\
\hline A-1-332 & 45.045302 & 6.313245 & 1464 & Dauphinois & Upper Lias & Slate & 12 & 0.69 & 332 & 8 \\
\hline A-1-333 & 45.040348 & 6.30609 & 1592 & Dauphinois & Lower Dogger & Slate & 12 & 0.71 & 326 & 4 \\
\hline A-1-334 & 45.039006 & 6.304639 & 1587 & Dauphinois & Lower Dogger & Slate & 11 & 0.70 & 328 & 4 \\
\hline A-1-337 & 45.052165 & 6.288855 & 1806 & Dauphinois & Lower Dogger & Slate & 13 & 0.70 & 330 & 4 \\
\hline$A-1-342$ & 45.076795 & 6.338908 & 2119 & Dauphinois & Middle Dogger & Limestone & 11 & 0.64 & 326 & 4 \\
\hline A-1-345(2) & 45.00973 & 6.26403 & 3193 & Dauphinois & Upper Lias & Slate & 12 & 0.69 & 335 & 5 \\
\hline A-2-002 & 45.16481 & 5.851862 & 813 & Dauphinois & Lower Dogger & Slate & 12 & 0.62 & 306 & 13 \\
\hline A-2-003 & 45.162054 & 5.81894 & 393 & Dauphinois & Middle Dogger & Limestone & 10 & 0.62 & 306 & 6 \\
\hline A-3-019 & 44.526656 & 6.726225 & 1690 & Embrunais-Ubaye & Cretaceous & Helm. Flysch & 12 & 0.59 & 262 & 6 \\
\hline A-4-005 & 45.052408 & 6.390277 & 2355 & Dauphinois & Priabonian & Flysch & 12 & 0.61 & 296 & 9 \\
\hline A-4-006 & 45.05279 & 6.40051 & 2379 & Dauphinois & Priabonian & Flysch & 12 & 0.61 & 288 & 6 \\
\hline A-4-010 & 45.06035 & 6.4223 & 2758 & Tête Noire & Cretaceous & Helm. Flysch & 12 & 0.59 & 265 & 8 \\
\hline A-4-011 & 45.06062 & 6.42282 & 2772 & Tête Noire & Cretaceous & Helm. Flysch & 11 & 0.58 & 261 & 9 \\
\hline A-4-014 & 45.063536 & 6.412644 & 2670 & Subbriançonnais & Eocene & Flysch & 12 & 0.59 & 267 & 6 \\
\hline$A-4-039 c 1$ & 45.04773 & 6.13796 & 1072 & Grandes Rousses & Carboniferous & Sandstone & 15 & 0.63 & 319 & 7 \\
\hline A-4-042 & 45.044332 & 6.15657 & 1064 & Dauphinois & Lower Dogger & Slate & 15 & 0.69 & 335 & 14 \\
\hline A-4-044 & 45.042854 & 6.168657 & 1462 & Dauphinois & Lower Dogger & Slate & 12 & 0.70 & 329 & 5 \\
\hline A-4-055 & 45.0421 & 6.35506 & 1770 & Dauphinois & Lower Dogger & Slate & 12 & 0.69 & 335 & 3 \\
\hline A-4-057 & 45.016852 & 6.039292 & 1509 & Dauphinois & Lower Lias & Limestone & 12 & 0.69 & 334 & 2 \\
\hline A-4-121 & 44.95072 & 5.96606 & 978 & Dauphinois & Lower Lias & Limestone & 10 & 0.64 & 326 & 7 \\
\hline A-4-122 & 44.89179 & 5.8778 & 695 & Dauphinois & Lower Lias & Limestone & 12 & 0.61 & 298 & 10 \\
\hline A-4-123 & 44.87871 & 5.7535 & 793 & Dauphinois & Lower Dogger & Slate & 12 & 0.60 & 279 & 9 \\
\hline A-4-124 & 44.87459 & 5.71011 & 667 & Dauphinois & Lower Lias & Limestone & 14 & 0.64 & 334 & 6 \\
\hline A-4-126 & 44.96182 & 5.81198 & 1181 & Dauphinois & Upper Lias & Slate & 11 & 0.63 & 314 & 8 \\
\hline A-4-140 & 45.33314 & 6.33442 & 1137 & Dauphinois & Upper Lias & Slate & 11 & 0.70 & 331 & 3 \\
\hline A-4-196 & 44.789297 & 6.45698 & 1671 & Dauphinois & Priabonian & Flysch & 11 & 0.64 & 330 & 5 \\
\hline A-4-197 & 45.03796 & 5.7054 & 403 & Dauphinois & Upper Lias & Slate & 12 & 0.69 & 334 & 4 \\
\hline A-4-198 & 45.04444 & 5.69423 & 309 & Dauphinois & Middle Dogger & Limestone & 11 & 0.64 & 325 & 6 \\
\hline$A-4-199$ & 45.04834 & 5.68057 & 340 & Dauphinois & Middle Dogger & Limestone & 12 & 0.61 & 296 & 5 \\
\hline A-4-200 & 45.01018 & 5.63507 & 499 & Subalpine chain & Lower Malm & Marls & 12 & 0.54 & 208 & 9 \\
\hline A-4-201 & 45.00197 & 5.62223 & 741 & Subalpine chain & Lower Malm & Marls & 14 & & $<200$ & \\
\hline A-4-223 & 45.013605 & 6.283496 & 2509 & Dauphinois & Lower Lias & Limestone & 11 & 0.68 & 338 & 4 \\
\hline$A-4-231$ & 44.63593 & 6.56532 & 912 & Subbriançonnais & Eocene & Flysch & 16 & 0.62 & 302 & 10 \\
\hline A-4-232 & 44.55958 & 6.47881 & 883 & Vocontian domain & Dogger/Malm & Black Shale & 13 & 0.62 & 308 & 5 \\
\hline A-4-233 & 44.58166 & 6.39937 & 1211 & Vocontian domain & Dogger/Malm & Black Shale & 11 & 0.59 & 271 & 11 \\
\hline A-4-235 & 44.5549 & 6.34229 & 1246 & Vocontian domain & Dogger/Malm & Black Shale & 11 & 0.58 & 253 & 10 \\
\hline$A-4-236$ & 44.714333 & 6.156877 & 1667 & Dauphinois & Upper Lias & Slate & 11 & 0.56 & 228 & 8 \\
\hline$A-4-238$ & 44.713257 & 6.167974 & 1960 & Dauphinois & Upper Lias & Slate & 12 & 0.54 & 202 & 4 \\
\hline$A-4-239 b$ & 44.714389 & 6.168411 & 1982 & Dauphinois & Priabonian & Flysch & 13 & & $<200$ & \\
\hline$A-4-242$ & 45.027604 & 6.312056 & 2228 & Dauphinois & Lower Lias & Limestone & 10 & 0.64 & 333 & 8 \\
\hline$A-4-244$ & 44.83378 & 5.93966 & 1002 & Dauphinois & Upper Lias & Slate & 11 & 0.57 & 237 & 7 \\
\hline A-4-247 & 44.844446 & 6.127314 & 2055 & Dauphinois & Lower Lias & Limestone & 12 & 0.69 & 334 & 2 \\
\hline$A-5-1$ & 44.867686 & 5.61239 & 847 & Subalpine chain & Lower Malm & Marls & 13 & 0.54 & 204 & 14 \\
\hline$A-5-2$ & 44.92326 & 5.63483 & 829 & Dauphinois & Middle Dogger & Limestone & 11 & 0.61 & 288 & 7 \\
\hline$A-5-3$ & 44.95121 & 5.60154 & 788 & Subalpine chain & Upper Dogger & Marls & 11 & & $<200$ & \\
\hline$A-5-4$ & 44.9613 & 5.58629 & 701 & Subalpine chain & Lower Malm & Marls & 12 & & $<200$ & \\
\hline$A-5-5$ & 44.92913 & 5.63472 & 819 & Dauphinois & Middle Dogger & Limestone & 11 & 0.60 & 286 & 5 \\
\hline$A-5-6$ & 44.9058 & 5.6258 & 902 & Subalpine chain & Upper Dogger & Marls & 15 & 0.56 & 227 & 23 \\
\hline A-4-154 & 45.25002 & 6.78357 & 1438 & Subbriançonnais & Lias & Limestone & 12 & 0.51 & 412 & 5 \\
\hline$A-4-228$ & 44.814212 & 6.567413 & 1147 & Dent Parraché & Malm & Limestone & 12 & 0.61 & 291 & 6 \\
\hline
\end{tabular}

Table 1 


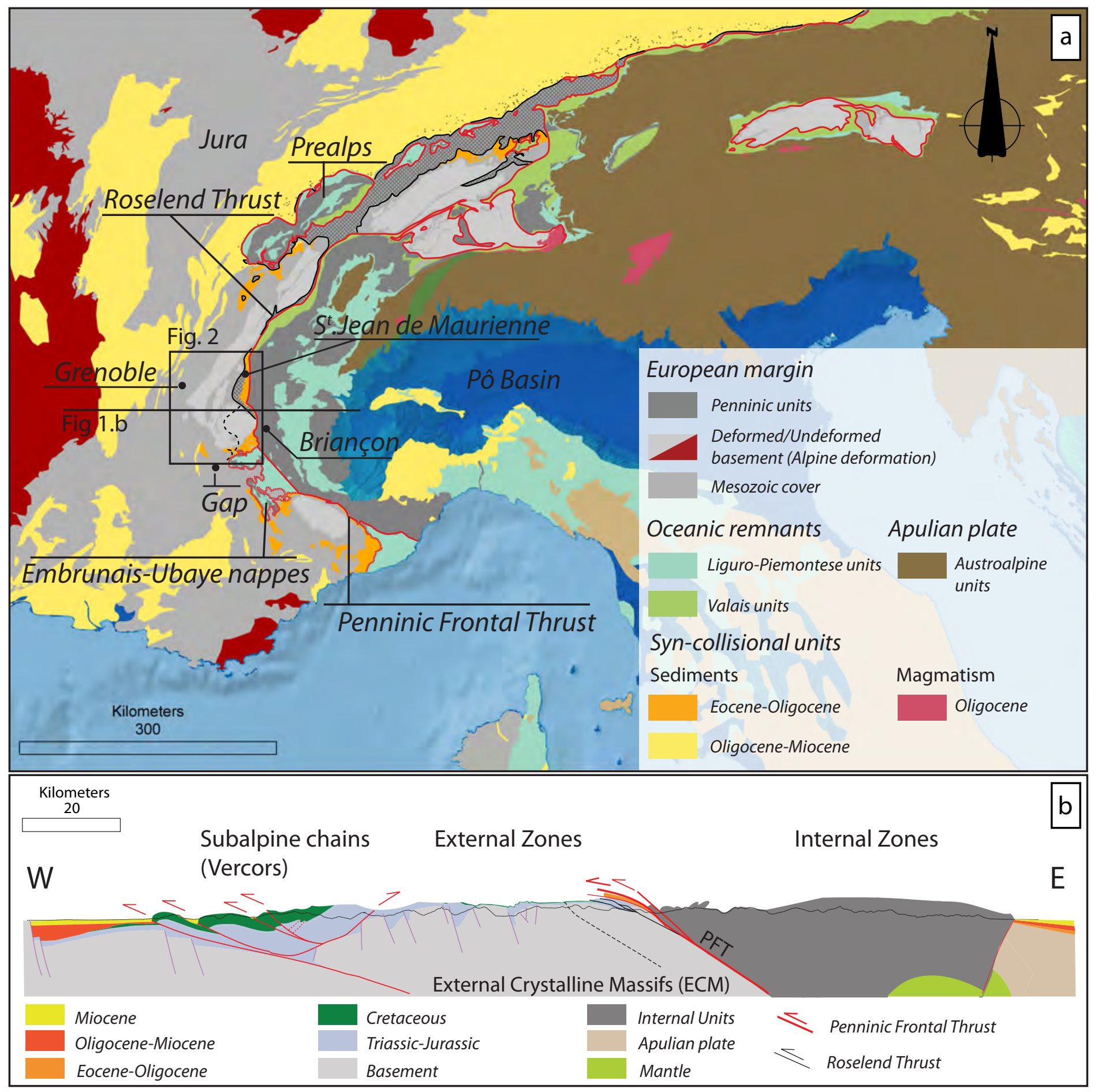

\section{Figure 1}




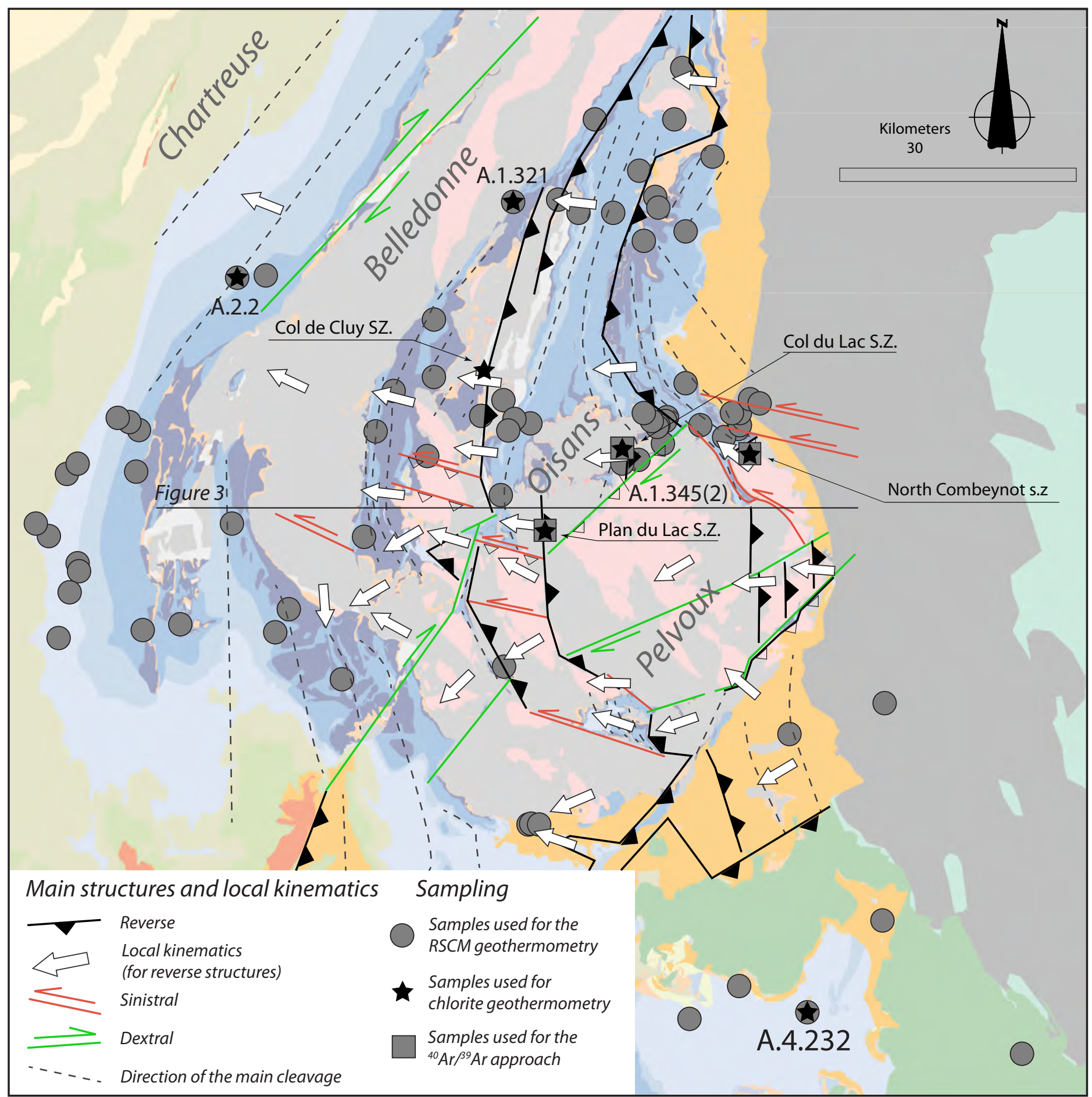

Figure 2 


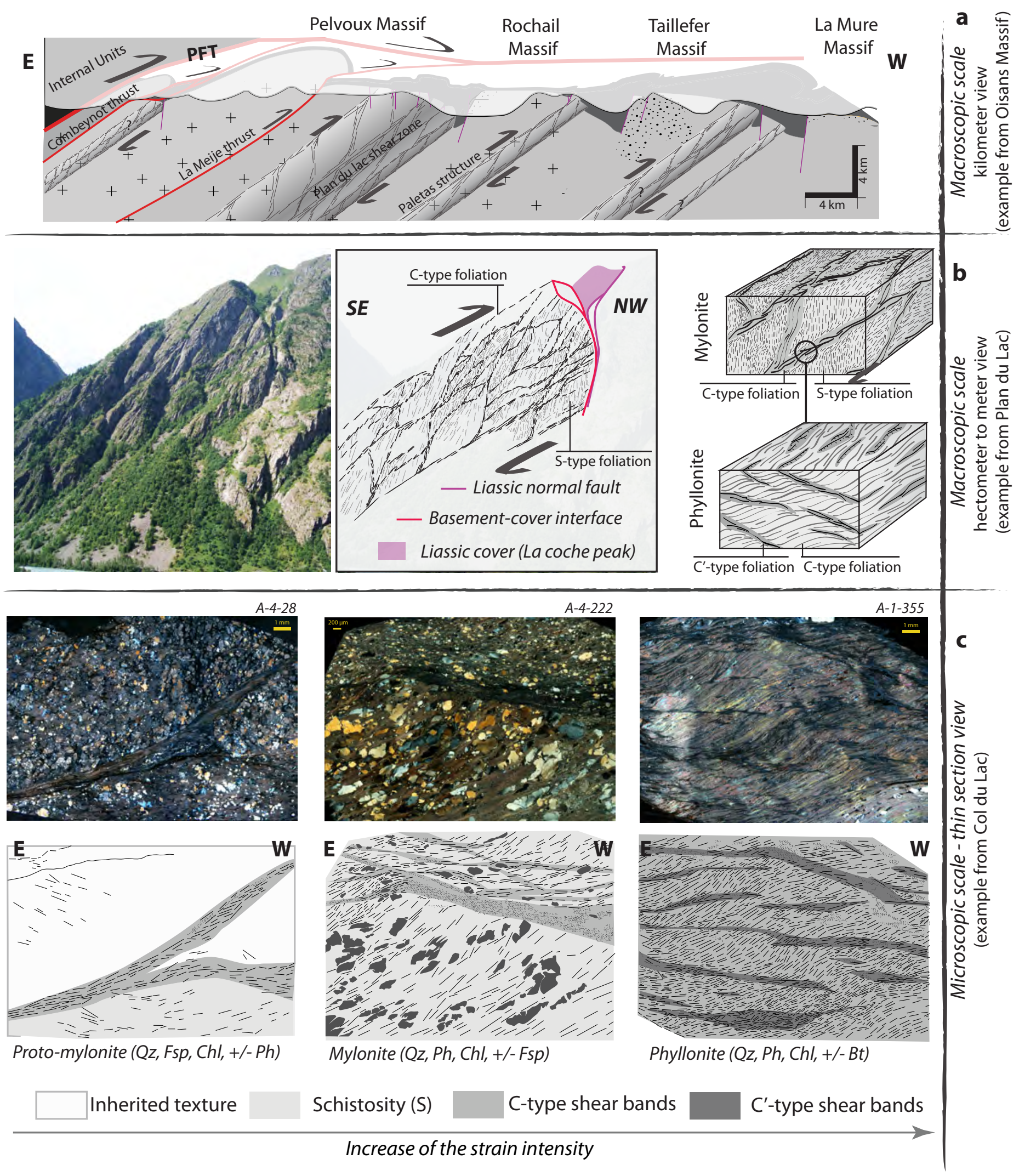

\section{Figure 3}



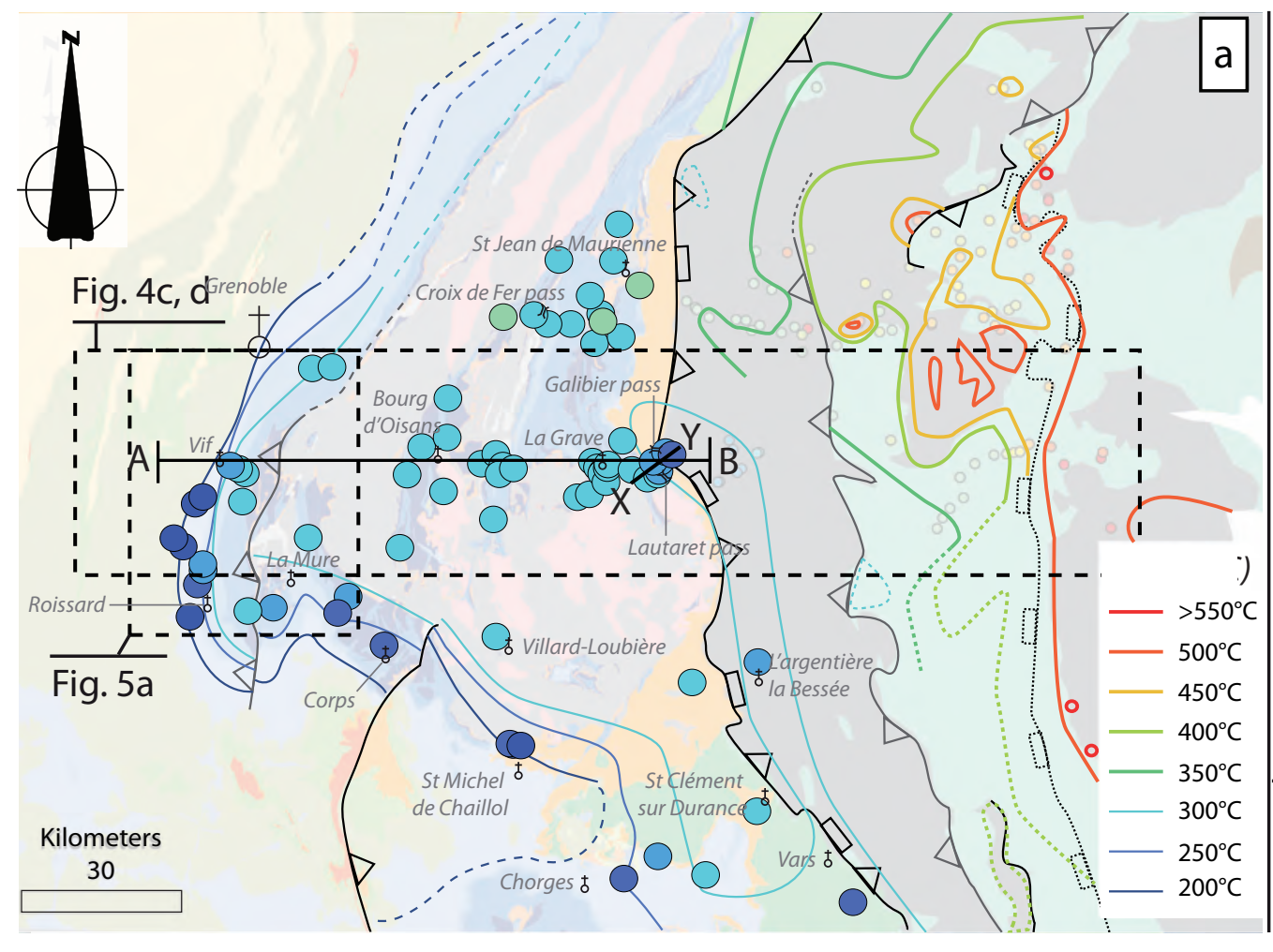

Illite crystallinity

b
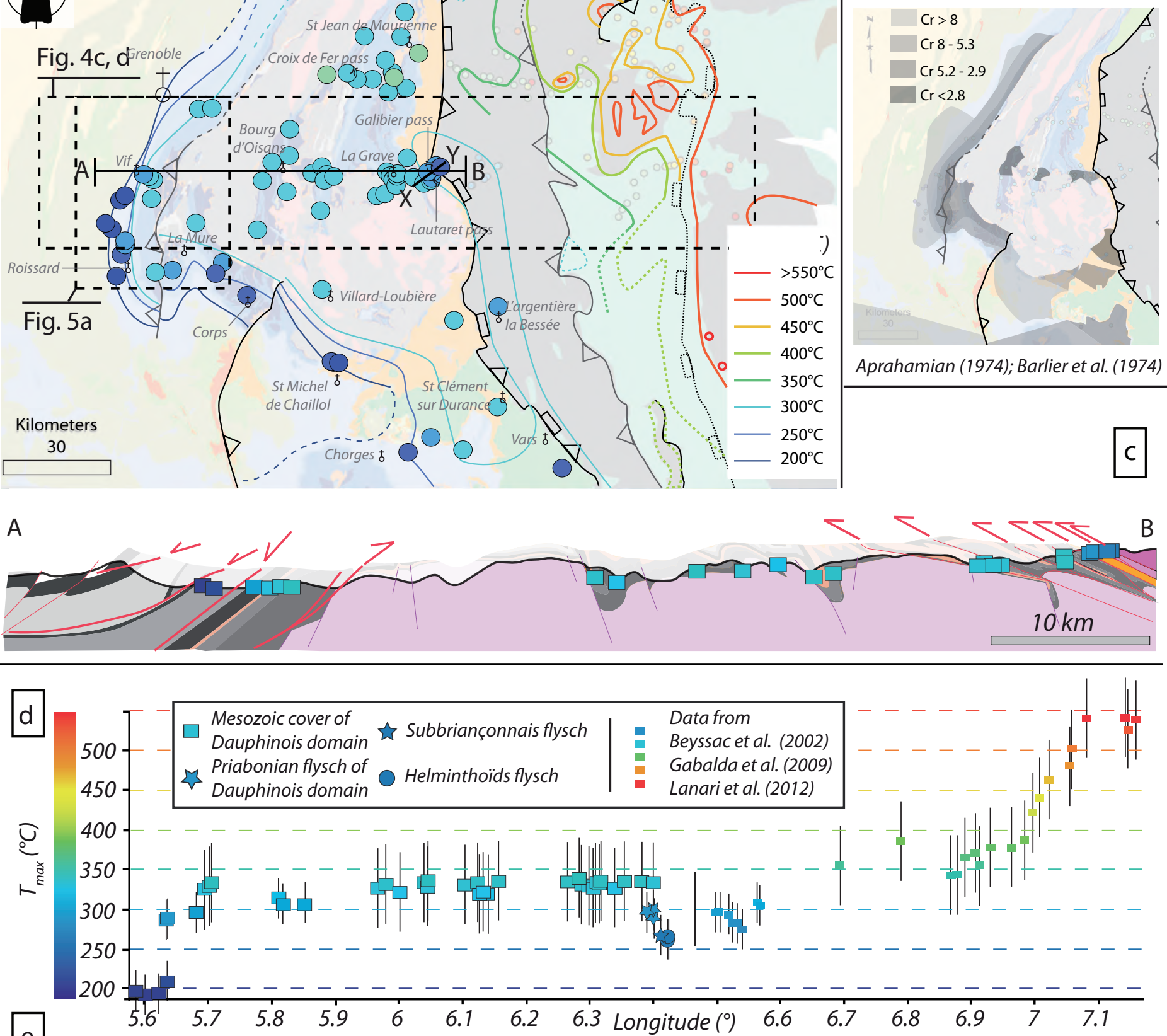

e

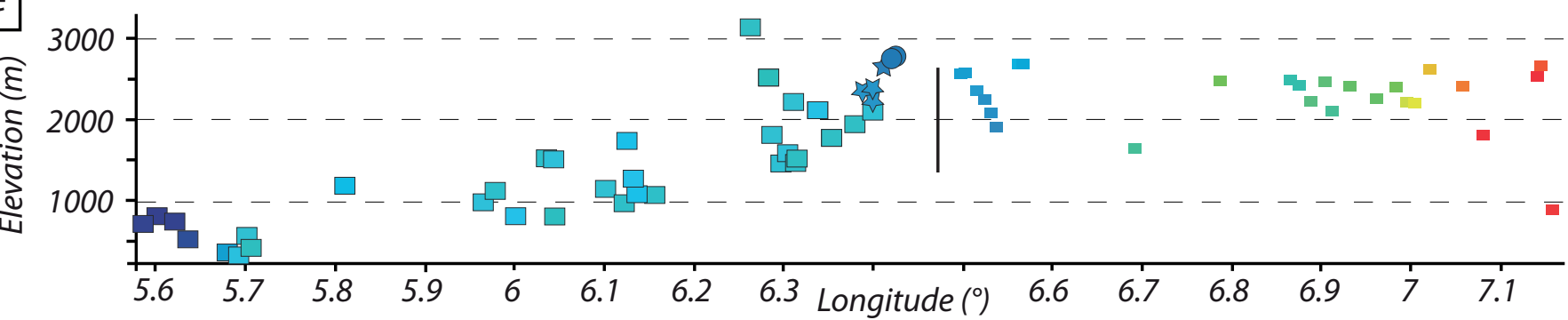

Figure 4 

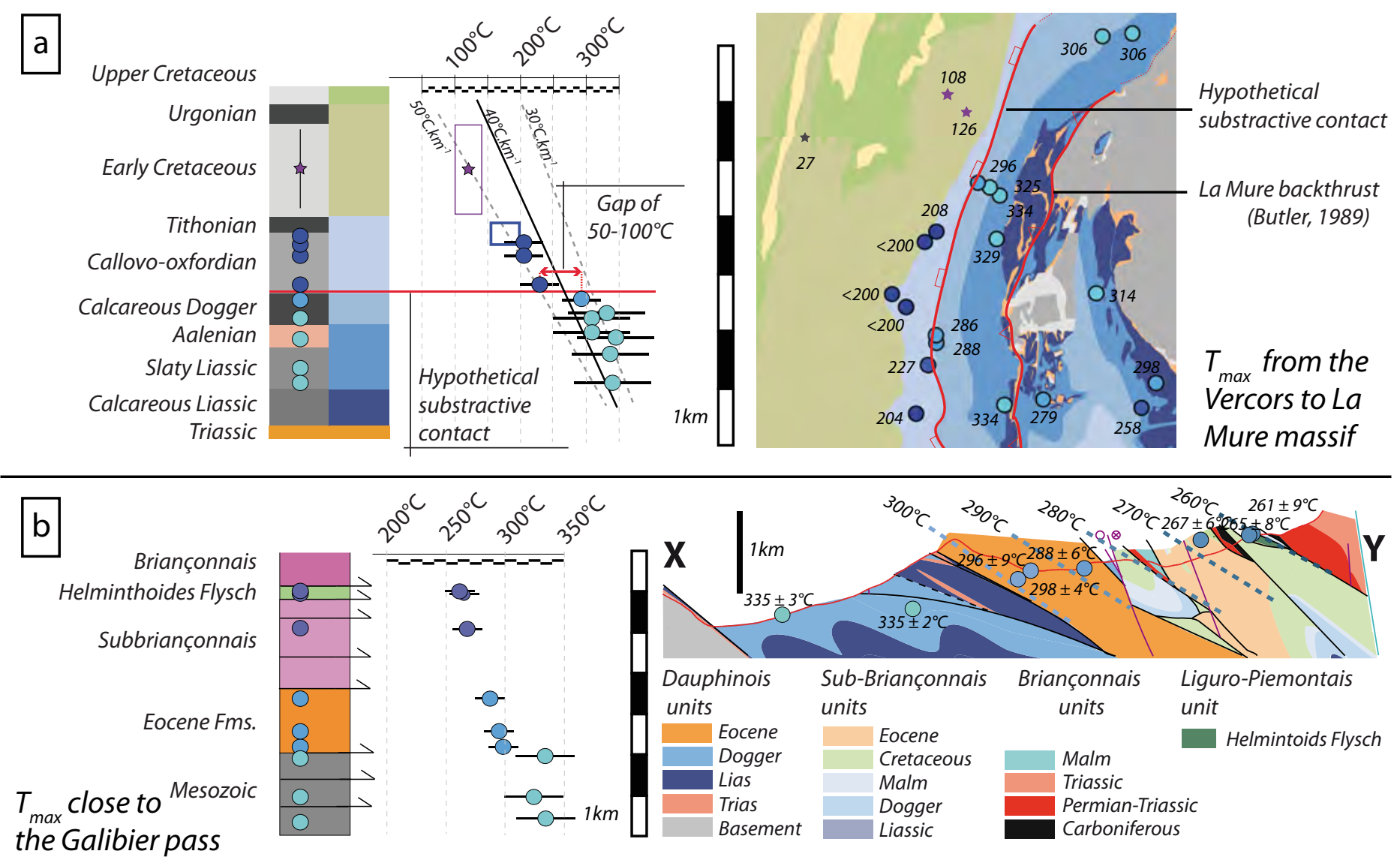

Figure 5 

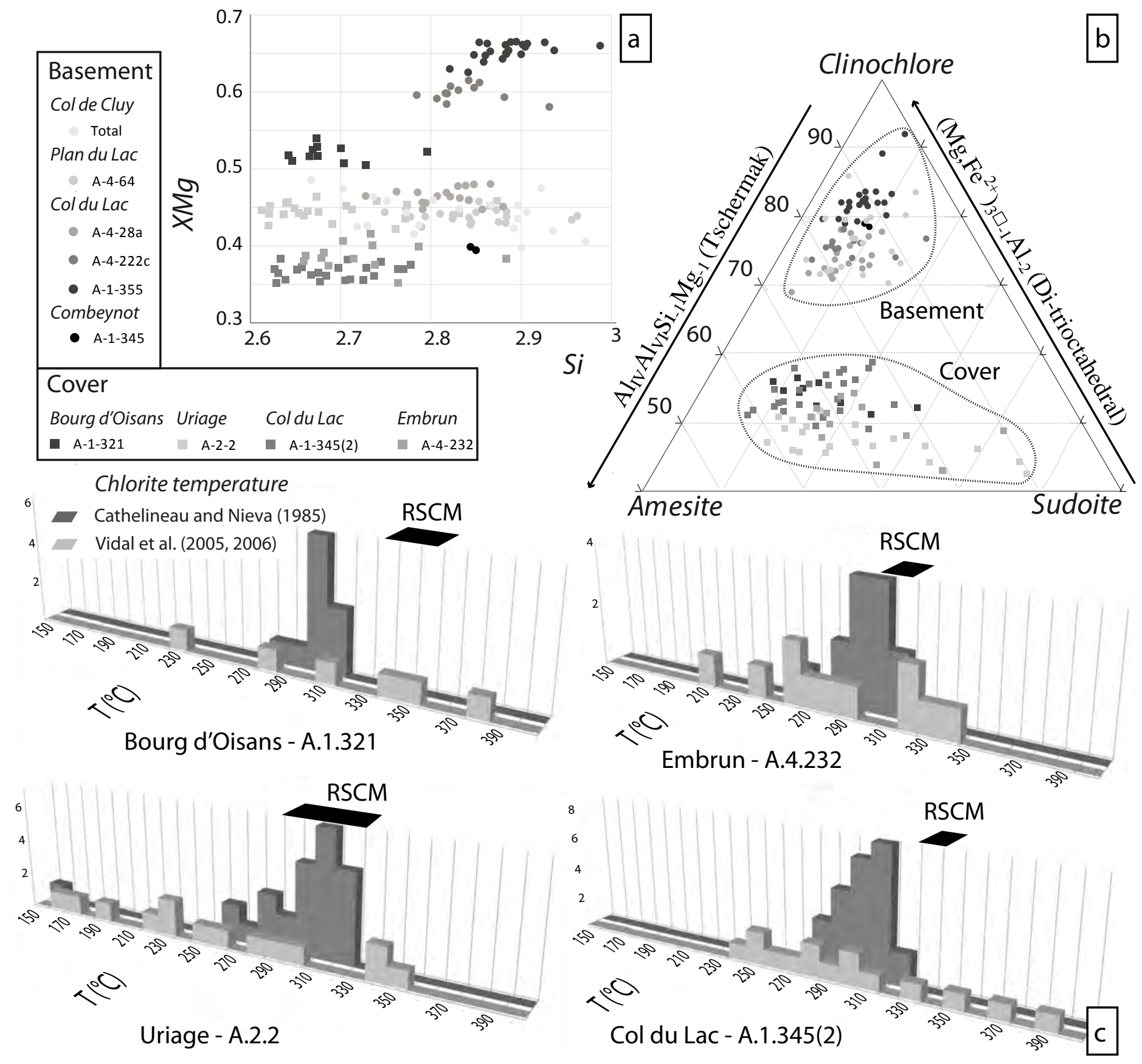

\section{Figure 6}




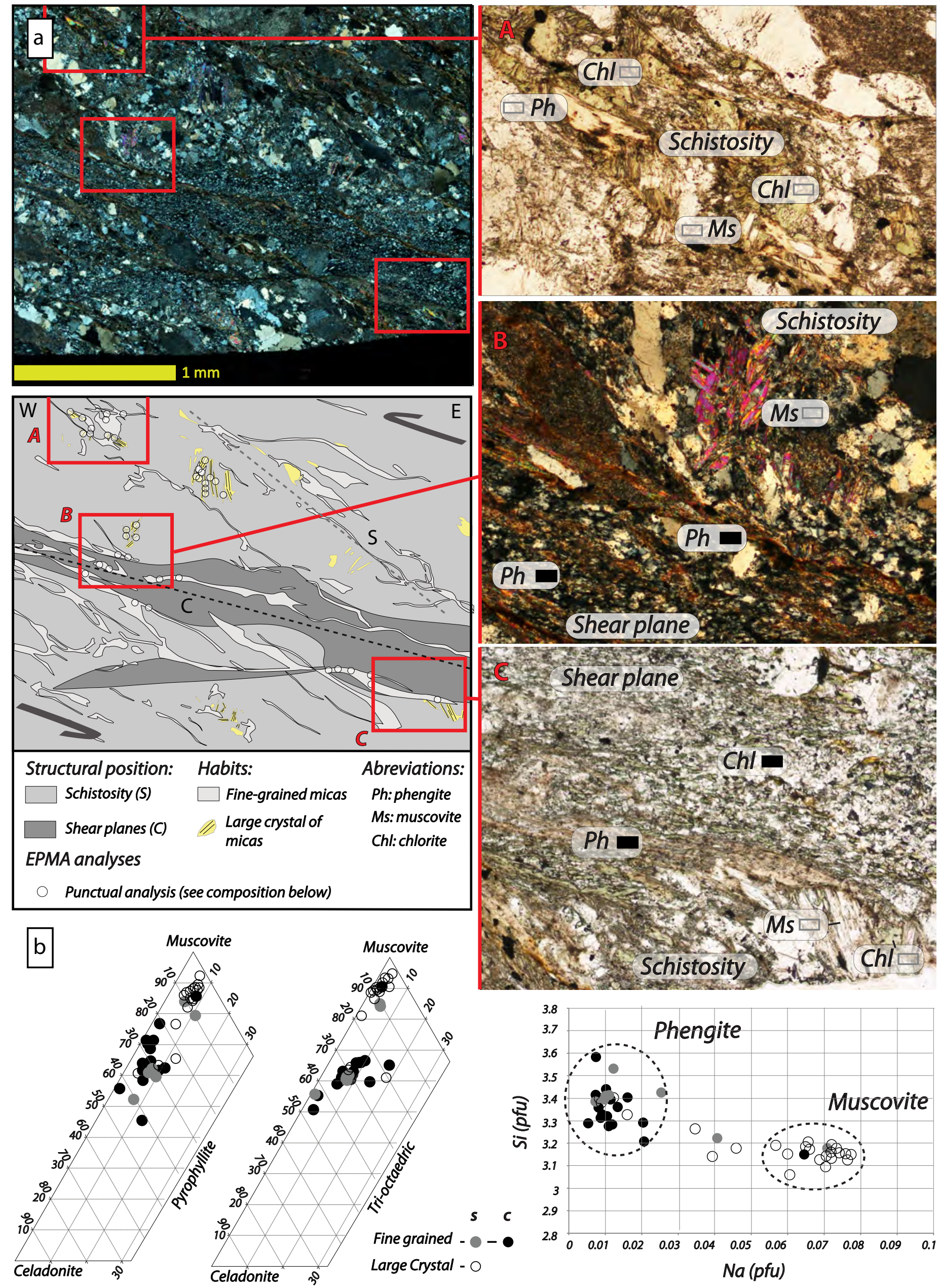

Figure 7 

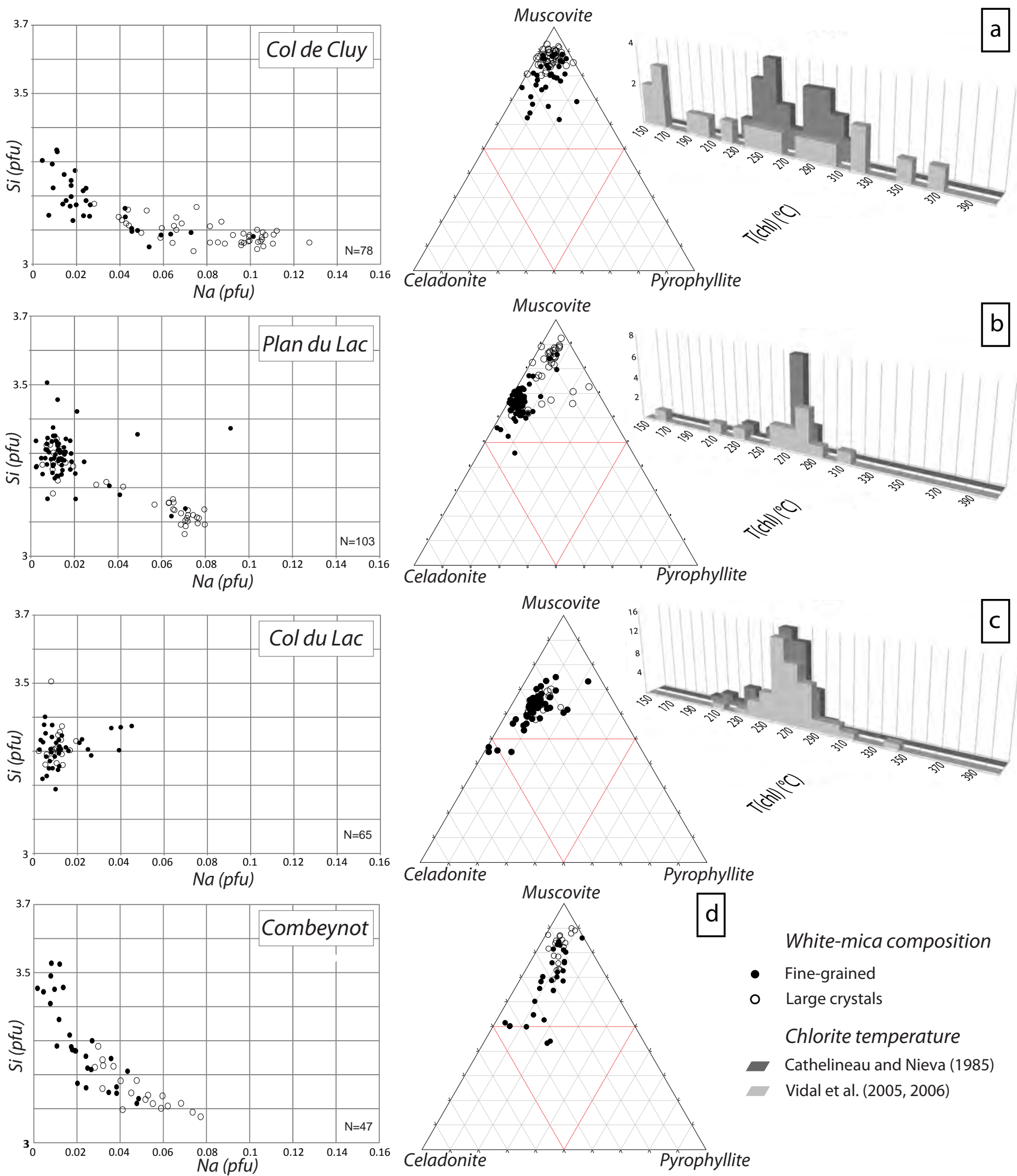

White-mica composition

- Fine-grained

- Large crystals

Chlorite temperature

Cathelineau and Nieva (1985)

Vidal et al. $(2005,2006)$

Figure 8 


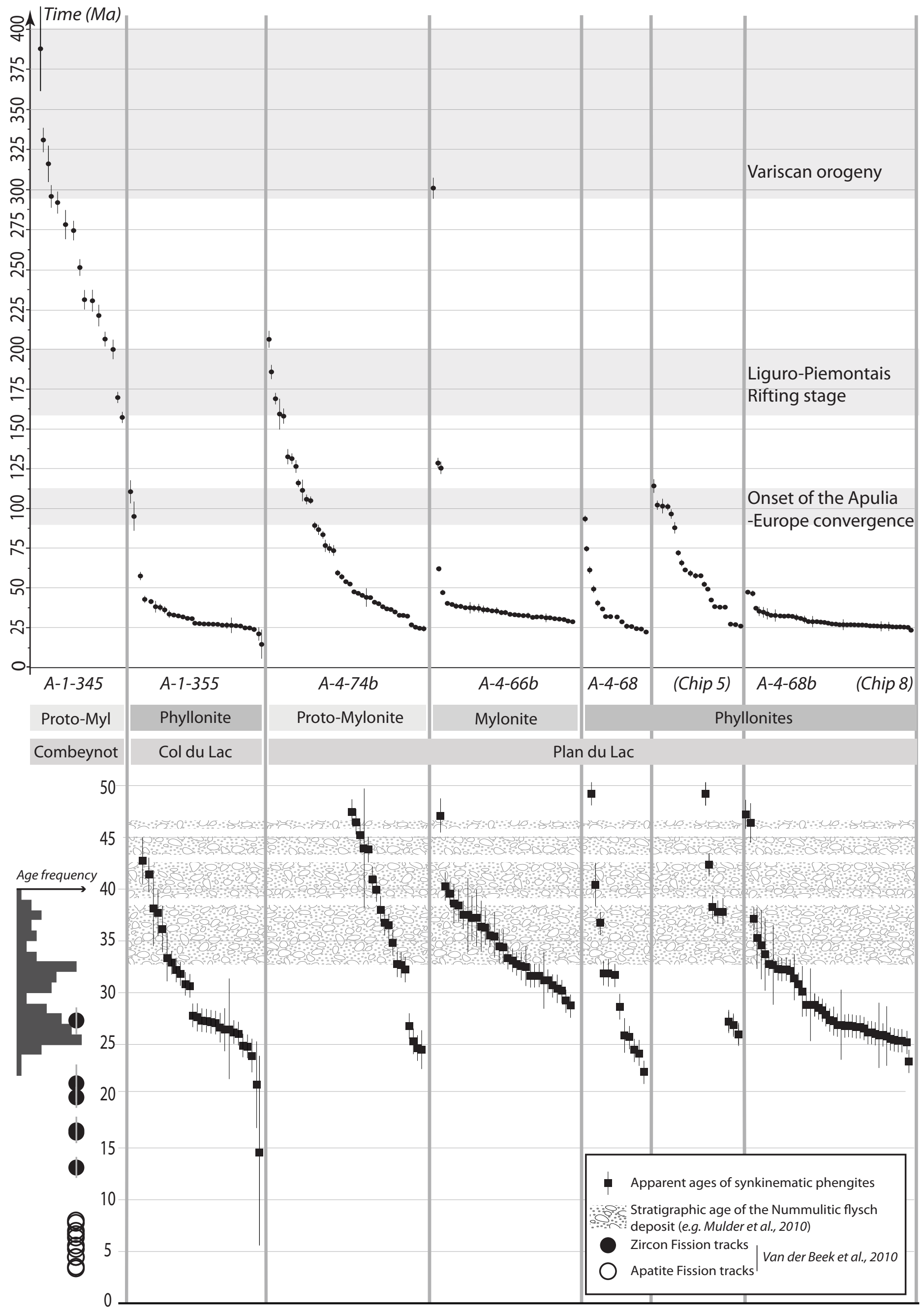

Figure 9 


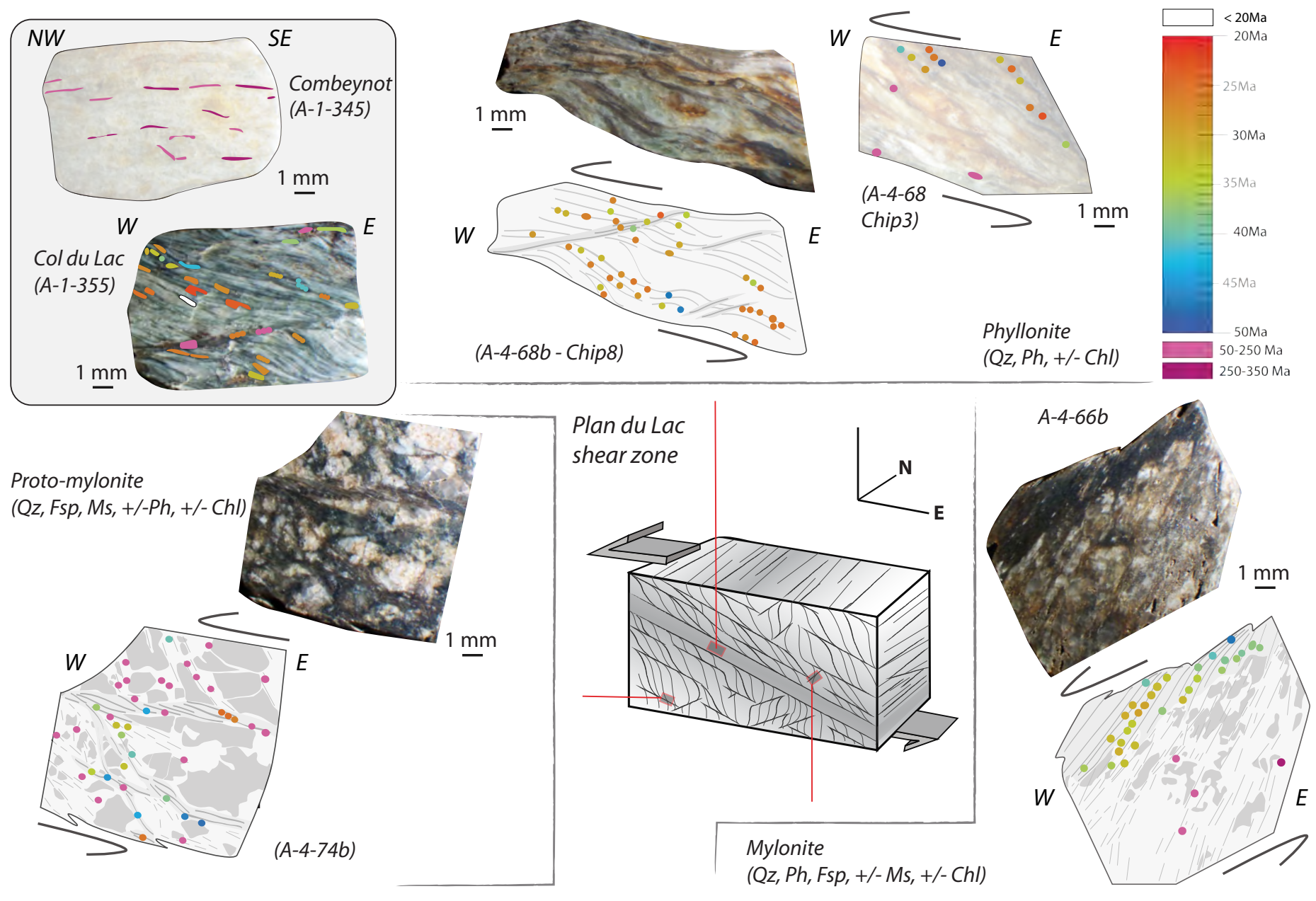

Figure 10 


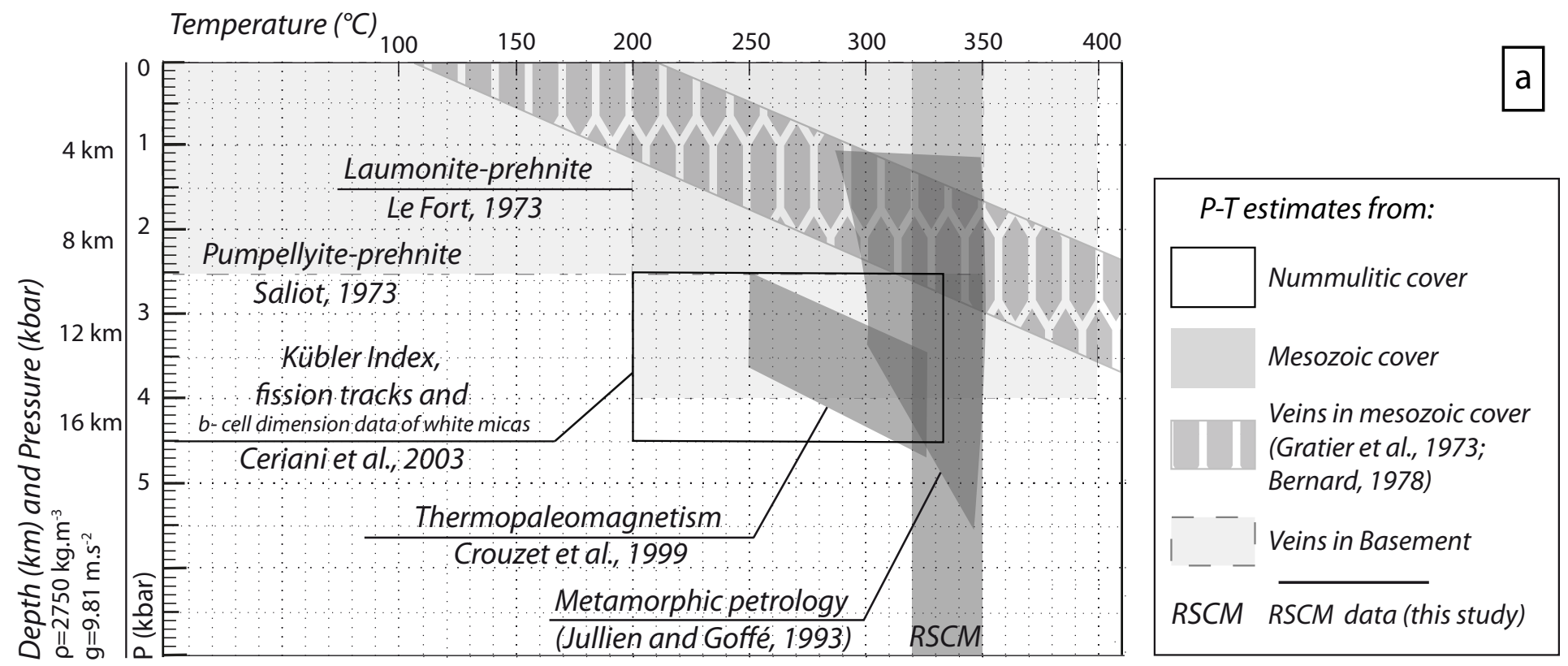

\begin{tabular}{|c|}
\hline Metamorphic conditions \\
RSCM (This study) \\
TChl-cover (This study) \\
TChl-basement (This study) \\
Age-constraints \\
>on peak-conditions: \\
K/Ar dating \\
Phengite (Nziengui, 1993) \\
>on deformation: \\
Ar/Ar dating \\
Phengite (This study) \\
>on cooling \\
Thermopalaeomagnetism \\
(Crouzet et al., 2001) \\
Zircon Fission Tracks \\
(Van der Beek, 2010) \\
Apatite Fission Tracks \\
(Sabil, 1995; \\
Van der Beek, 2010; \\
Beucher at al., 2012)
\end{tabular}
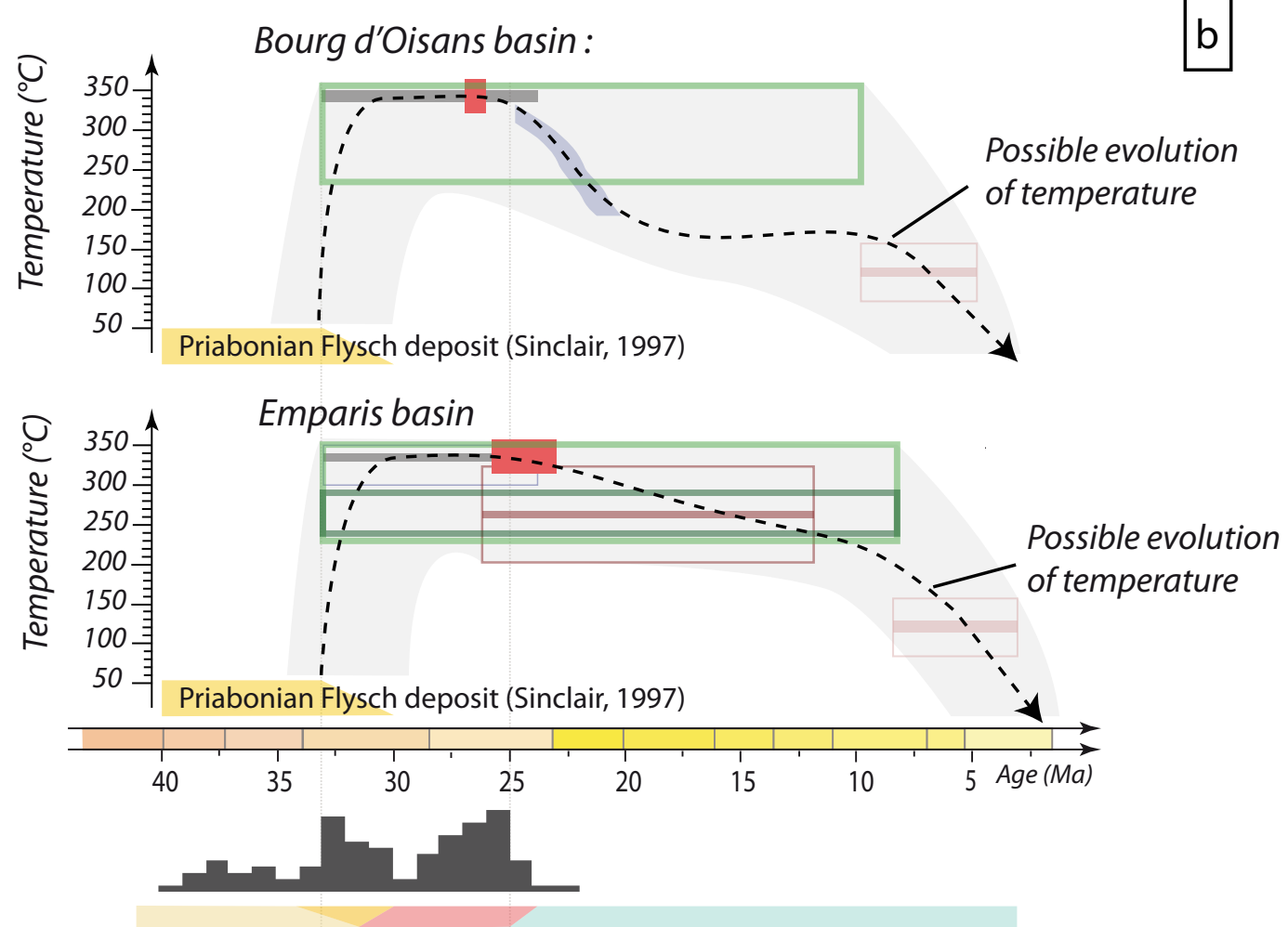

Sedimentation Burial Metamorphicpeak Cooling

\section{Figure 11}



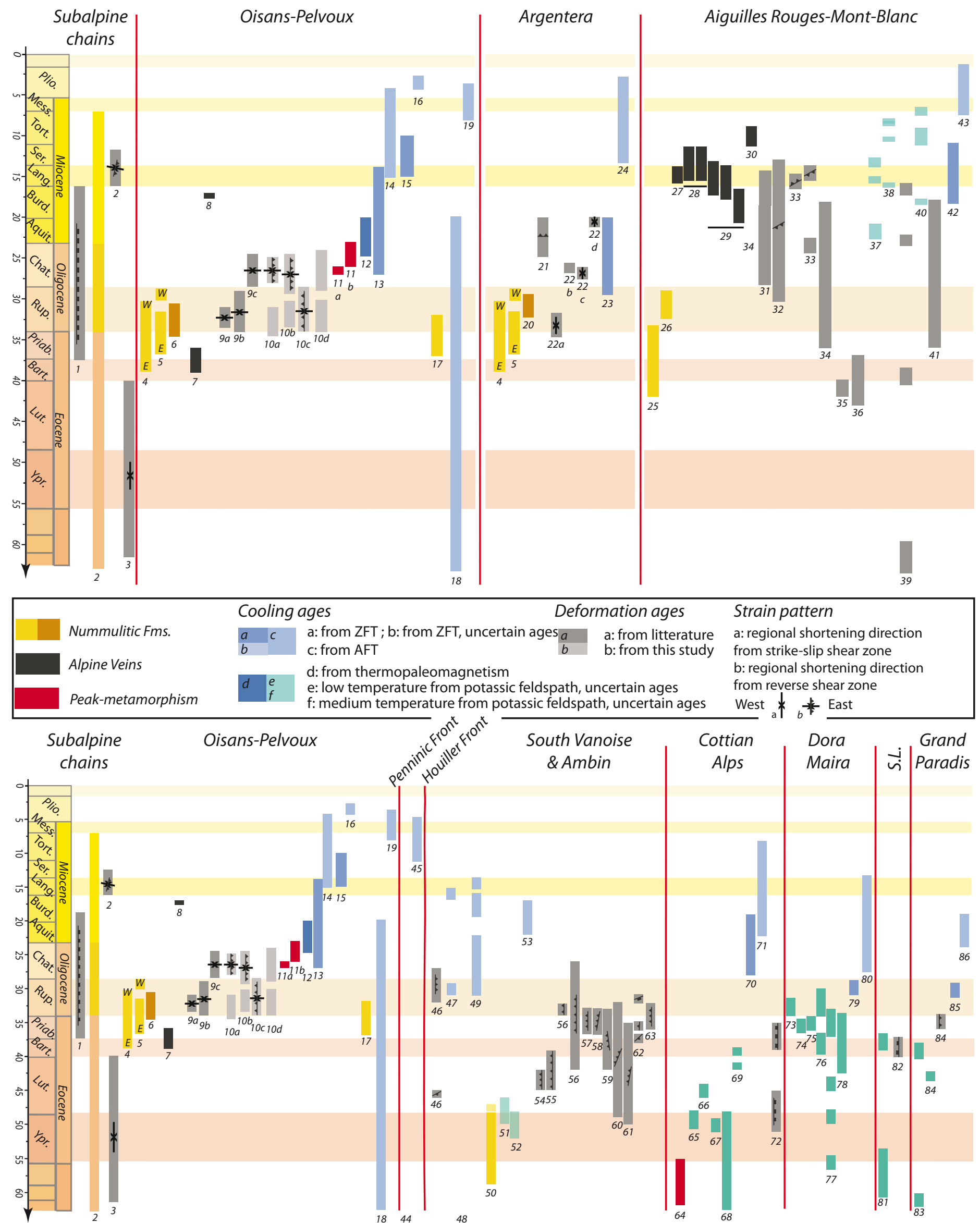

Figure 12 
3: Crustal ramp and exhumation of the ECM

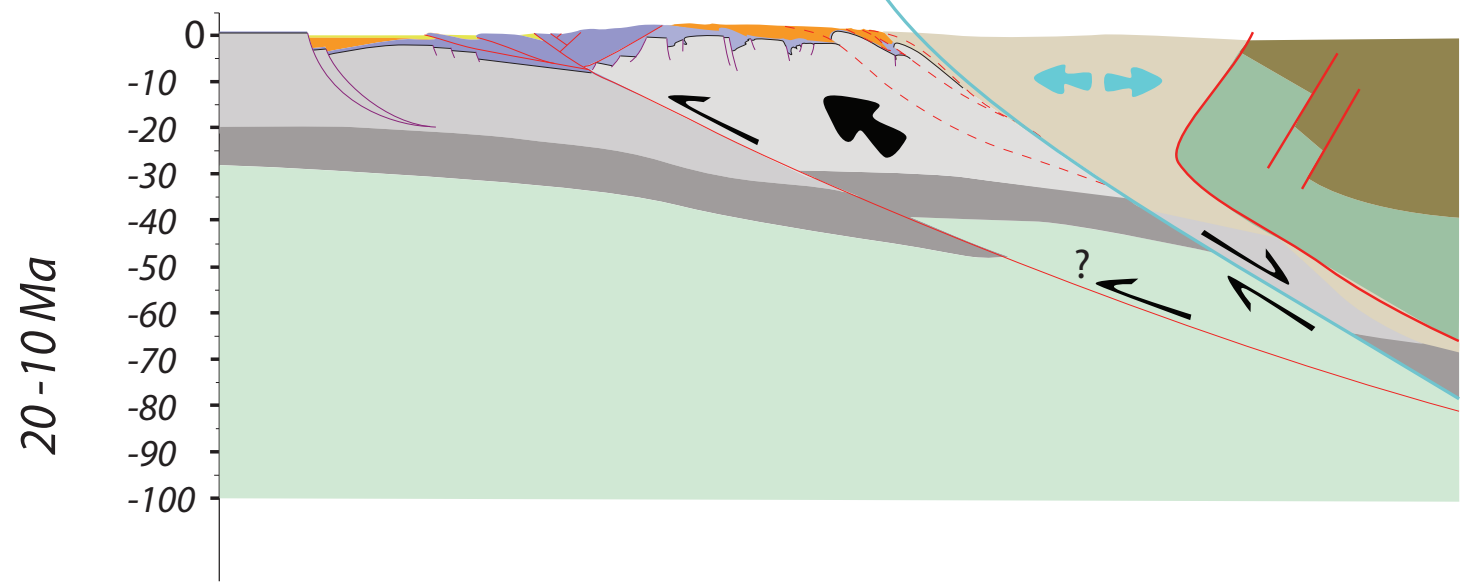

2: Internal shortening and progressive strain localisation
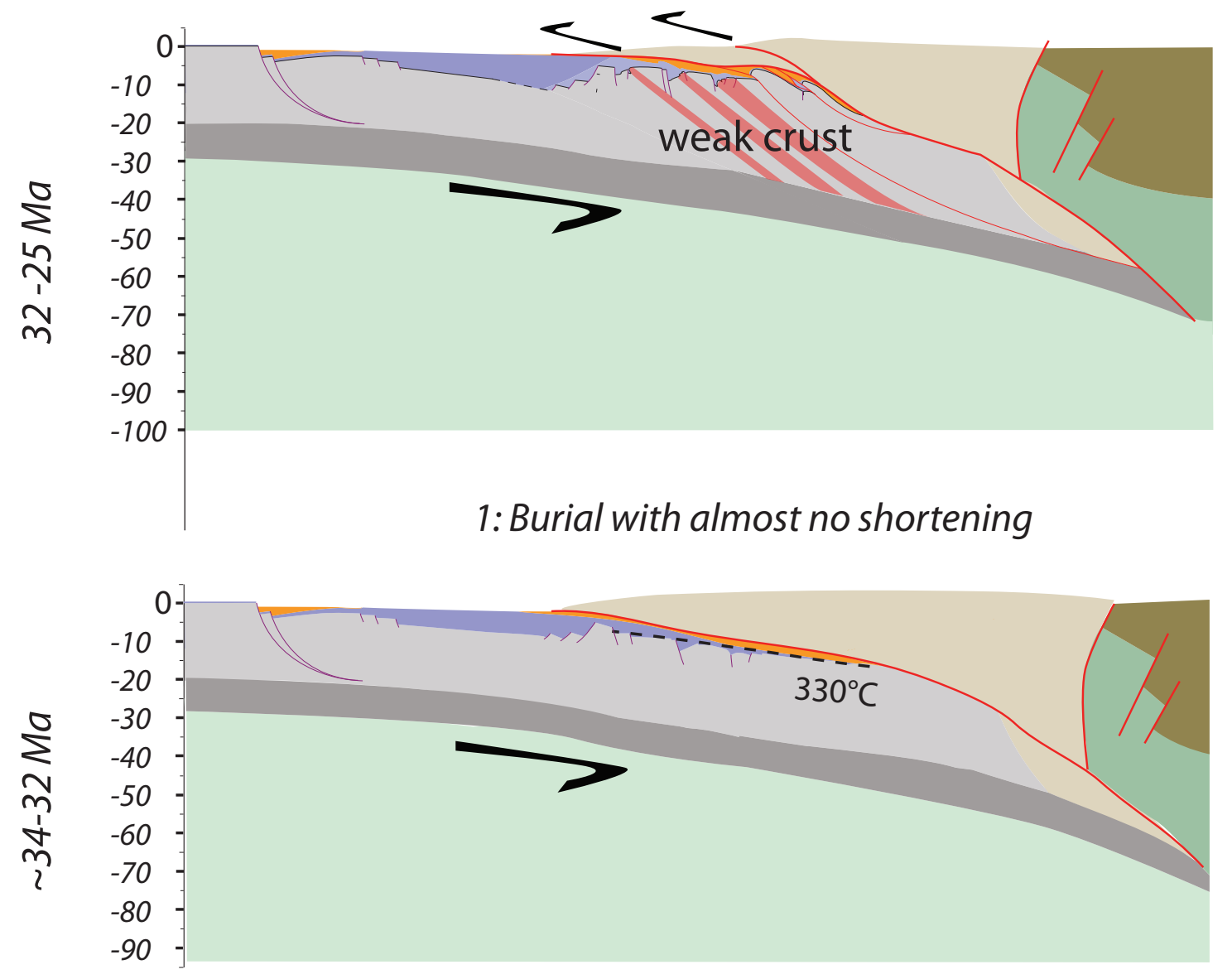

European plate :

Apulian plate :
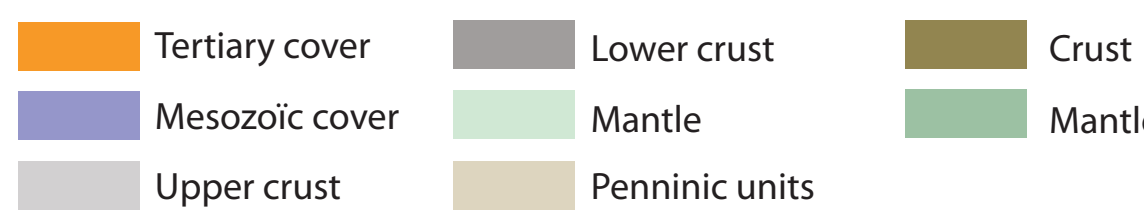

Penninic units

Figure 13 